\title{
(1) Pिmhalina
}

Helena

Autor(es): $\quad$ Eurípides; Oliveira, Alessandra Cristina Jonas Neves, trad.

Publicado por: Imprensa da Universidade de Coimbra

URL persistente:

URI:http://hdl.handle.net/10316.2/37387

DOI:

DOI:http://dx.doi.org/10.14195/978-989-26-1047-4

Accessed : $\quad$ 26-Apr-2023 00:53:32

A navegação consulta e descarregamento dos títulos inseridos nas Bibliotecas Digitais UC Digitalis, UC Pombalina e UC Impactum, pressupõem a aceitação plena e sem reservas dos Termos e Condições de Uso destas Bibliotecas Digitais, disponíveis em https://digitalis.uc.pt/pt-pt/termos.

Conforme exposto nos referidos Termos e Condições de Uso, o descarregamento de títulos de acesso restrito requer uma licença válida de autorização devendo o utilizador aceder ao(s) documento(s) a partir de um endereço de IP da instituição detentora da supramencionada licença.

Ao utilizador é apenas permitido o descarregamento para uso pessoal, pelo que o emprego do(s) título(s) descarregado(s) para outro fim, designadamente comercial, carece de autorização do respetivo autor ou editor da obra.

Na medida em que todas as obras da UC Digitalis se encontram protegidas pelo Código do Direito de Autor e Direitos Conexos e demais legislação aplicável, toda a cópia, parcial ou total, deste documento, nos casos em que é legalmente admitida, deverá conter ou fazer-se acompanhar por este aviso. 
Série Autores Gregos e Latinos

\section{EURÍPIDES}

Helena

TraduÇão do GREgo, INTROdUÇÃo E COMENTÁRIO Alessandra Cristina Jonas Neves Oliveira

IMPRENSA DA UNIVERSIDADE DE COIMBRA COIMBRA UNIVERSITY PRESS

ANNABLUME 
Apresentaçáo: Esta série procura apresentar em língua portuguesa obras de autores gregos, latinos e neolatinos, em tradução feita diretamente a partir da língua original. Além da tradução, todos os volumes são também caraterizados por conterem estudos introdutórios, bibliografia crítica e notas. Reforça-se, assim, a originalidade científica e o alcance da série, cumprindo o duplo objetivo de tornar acessíveis textos clássicos, medievais e renascentistas a leitores que não dominam as línguas antigas em que foram escritos. Também do ponto de vista da reflexão académica, a coleçáo se reveste no panorama lusófono de particular importância, pois proporciona contributos originais numa área de investigação científica fundamental no universo geral do conhecimento e divulgaçáo do património literário da Humanidade.

Breve nota curricular sobre o autor da tradução

Alessandra Cristina Jonas Neves Oliveira é licenciada em Línguas e Literaturas Clássicas pela Universidade de Coimbra. A sua tese de mestrado foi justamente dedicada à Helena de Eurípides, que agora publica numa forma revista e ampliada. 
Série Autores Gregos e Latinos 


\title{
Estruturas Editoriais
}

\section{Série Autores Gregos e Latinos}

ISSN: $2183-220 \mathrm{X}$

\section{Diretoras Principais}

Main Editors

Carmen Leal Soares

Universidade de Coimbra

Maria de Fátima Silva

Universidade de Coimbra

\section{Assistentes Editoriais}

Editoral Assistants

Elisabete Cação, João Pedro Gomes, Nelson Ferreira

Universidade de Coimbra

\section{Comissão Científica}

EDitorial Board

\author{
Adriane Duarte \\ Frederico Lourenço \\ Universidade de Sáo Paulo \\ Universidade de Coimbra \\ Aurelio Pérez Jiménez \\ Joaquim Pinheiro \\ Universidad de Málaga \\ Universidade da Madeira \\ Graciela Zeccin \\ Lucía Rodríguez-Noriega Guillen \\ Universidade de La Plata \\ Fernanda Brasete \\ Universidade de Oviedo \\ Universidade de Aveiro \\ Fernando Brandão dos Santos \\ Maria José García Soler \\ UNESP, Campus de Araraquara \\ Jorge Deserto \\ Francesc Casadesús Bordoy \\ Susana Marques Pereira \\ Universitat de les Illes Balears \\ Universidade de Coimbra
}




\section{EURÍPIDES}

\section{Helena}

TRADUÇÃO DO GREGO, INTRODUÇÃo E COMENTÁRIO Alessandra Cristina Jonas Neves Oliveira 
Título Titue

Helena

Helen

Autor Author

Eurípides Euripides

TraduÇão do Grego, Introduçấo e COMENTÁRIo

Translation from the Greek, Introduction and Commentary

Alessandra Cristina Jonas Neves Oliveira

Editores Publishers

Imprensa da Universidade de Coimbra Annablume Editora * Comunicação

Coimbra University Press

www.uc.pt/imprensa_uc www.annablume.com.br

Contacto Contact

Contato Contact

imprensa@uc.pt

@annablume.com.br

Vendas online Online Sales

http://livrariadaimprensa.uc.pt

Coordenação Editorial Editorial Coordination

Imprensa da Universidade de Coimbra

Conceção Gráfica Graphics

Rodolfo Lopes, Nelson Ferreira

Infografia Infographics

Nelson Ferreira

Impressão e Acabamento Printed by

http://www.simoeselinhares.net46.net/

ISSN

2183-220X

ISBN

978-989-26-1046-7

ISBN Digital

978-989-26-1047-4

DOI

http://dx.doi.org/10.14195/978-989-

26-1047-4

Depósito Legal Legal Deposit

398617/15
(C) Setembro 2015

Annablume Editora * São Paulo

Imprensa da Universidade de Coimbra

Classica Digitalia Vniversitatis

Conimbrigensis

http://classicadigitalia.uc.pt

Centro de Estudos Clássicos e Humanísticos

da Universidade de Coimbra

Creative Commons CC-BY (http://creativecommons.org/licenses/by/3.0/pt/legalcode) 


\section{EURÍPIDES EURIPIDES}

\section{Helena \\ HELEN}

Traduçấ, InTroduçấo E Comentário POR

Translation, Introduction and Commentary by

Alessandra Cristina Jonas Neves Oliveira

Filiação Afeiliation

Universidade de Coimbra University of Coimbra

Resumo

Este livro pretende oferecer uma tradução, acompanhada de um estudo introdutório e de um amplo conjunto de notas, da Helena de Eurípides. No estudo introdutório são abordadas as questôes mais significativas na interpretação desta peça que figura entre as 'tragicomédias' do autor.

Palavras-chave

Eurípides, Helena, tragédia grega.

Abstract

This book offers a translation, with an introductory study and a large commentary, of Euripides' Helen. The introduction explores the main interpretative problems of a play that belongs to the famous 'escape tragedies' of Euripides.

KeYwords

Euripides, Helen, Greek tragedy. 


\section{Autora}

Alessandra Cristina Jonas Neves Oliveira é licenciada em Línguas e Literaturas Clássicas pela Universidade de Coimbra. A sua tese de mestrado foi justamente dedicada à Helena de Eurípides, que agora publica numa forma revista e ampliada.

AUTHOR

Alessandra Cristina Jonas Neves Oliveira did her graduation in Classical Studies in the University of Coimbra. Her master was a study of this same tragedy, the Helen of Euripides, she now publishes after revising and amplifying the results of that first research. 


\section{Sumário}

NOTA PRÉVIA

ESTUDO INTRODUTÓRIO

1. A recriação do mito: Herança e originalidade

2. Helena, uma peça de Antíteses.

2.1. a moldura sofística do argumento

2.2. Verdade-aparência: uma Helena 're-tratada'

2.3. Gregos vs. Bárbaros: o redefinir de fronteiras

3. Uma tragédia de ideias

HELENA

Bibliografia 
(Página deixada propositadamente em branco) 


\section{Nota PRÉvia}

$\mathrm{Na}$ nossa tradução do texto euripidiano, seguimos a edição fixada por J. Diggle (Oxford: 1994).

Sempre que possível, fizemos corresponder a versão portuguesa de antropónimos, topónimos, patronímicos e heortónimos à apresentada por F. Rebelo Gonçalves (Vocabulário da Lingua Portuguesa, Coimbra, 1966).

Para a citação de textos e autores gregos, adoptaram-se as abreviaturas sugeridas por H. G. Liddel e R. Scott (Greek-English Lexicon, Oxford, 1996) e, nas referências a publicaçôes periódicas, foram utilizadas as siglas de L'Année Philologique. 
(Página deixada propositadamente em branco) 


\section{A RECriaÇÃo do Mito: \\ HERANÇA E ORIGINALIDAdE}

Apresentada em 412 a.C. ${ }^{1}$, no rescaldo da derrota das tropas gregas na Sicília, ao comando de Alcibíades $^{2}$, e com as prolongadas hostilidades entre Atenas e Esparta ${ }^{3}$ a agravarem a vulnerabilidade da Hélade face à ameaça externa, a Helena surge como expressão incontida de um desejo de mudança um apelo do teatro à realidade (ou talvez o inverso) -, numa época favorável à renovação. Tróia representaria ainda, no imaginário grego, um espaço fundacional, monumento de valores ancestrais, resistentes ao tempo e ao devir. A guerra ali travada, palco de celebraçấo dos heróis e das virtudes guerreiras a que dáo corpo, não conheceria também mais do que uma perspectiva: a da Grécia triunfante sobre a Barbárie. E a mítica rainha de Esparta, causa deste confronto e rosto de todas as desgraças - o

${ }^{1}$ A data da representação da peça não é consensual, embora a generalidade dos autores aponte para 412 a.C., com base na informação de um escoliasta de Thesmoforiazousae, que inclui a Helena na trilogia da Andrómeda.

${ }^{2}$ Dono de uma beleza carismática e de conhecidos dotes oratórios, o general Alcíbides, que comandara a ruinosa expedição militar, havia persuadido os concidadáos atenienses da viabilidade desta empresa, que traria à polis inúmeros benefícios económicos. A derrota, ocorrida em 413 a.C. (vd. Th., 7.87.6, 8.1), e o desmoronar de um sonho que se revelara infundado, um ano antes da estreia da peça, está na origem de uma série de análises historicistas, em que Helena surge mesmo como prefiguração do general ateniense (e.g. M. Vickers, "Alcibiades on stage: Thesmophoriazusae and Helen", Historia 38/1, 1989, 41-65).

${ }^{3}$ A Guerra do Peloponeso, que opunha Atenas a Esparta, tivera início em 431a.C. e, apesar de interrompida em 421 a. C., fora retomada em 418. À data da representação da Helena, o conflito abeiraria já os vinte anos, não se prevendo ainda o fim das hostilidades entre ambas as potências gregas. 
"pecado original», no dizer de J. Assaël ${ }^{4}$-, seria, mais do que em qualquer outro momento da história da Grécia, a vítima ideal para sacrificar no altar da tragédia. Por isso, quando ousa, nesta peça, considerar a inocência de Helena, esvaziando de sentido a empresa troiana e colocando em causa o valor absoluto dos princípios que consagra, Eurípides vem dar um impulso revolucionário ao teatro, que progressivamente se converte numa nova forma de pensar o real - crítica, isenta, problematizante e, no fim de tudo, interventiva.

A mudança que propóe não se traduz, no entanto, numa anulação da tradição em favor das ideias emergentes. Sob o signo da sofística, que adquire crescente força e prestígio numa conjuntura de instabilidade, promove-se, antes, o debate entre os valores antigos, de matriz homérica, e os modernos, cada vez mais distantes de um ideal heróico a que o teatro se fidelizara.

A nova Helena afirma-se assim como símbolo perfeito desta dialéctica. Sem perder a ambiguidade que a caracteriza em Homero e carregando ainda, no nome e na imagem, o peso das acusaçōes que a tragédia - de Ésquilo a Eurípides $^{6}$-, lhe havia imputado, a Espartana apresenta-se agora como vítima inocente de uma ilusão. Levada por Hermes até às planícies egípcias e confiada por Zeus à guarda do piedoso faraó Proteu,

${ }^{4} \mathrm{~J}$. Assaël, "Les transformations du mythe dans l' Hélène d'Euripide", Pallas 33, 1987, 50.

${ }^{5}$ A respeito do tratamento da personagem em Ésquilo, vd. Ag., $62 \mathrm{sqq}$, 226, 404 sqq., 727 sqq., 745 sqq., 1455 sqq.. Paradigmático deste retrato que o trágico traça de Helena são os bem conhecidos versos em que, num hábil jogo vocabular, se explora a semelhança fónica do nome da Espartana com a raiz do verbo 'destruir', presente nos compostos 'destruidora de naus', 'destruidora de homens', 'destruidora de cidades' (Cf. A., 689-90).

${ }^{6}$ A Espartana é vituperada por nove personagens (quando exceptuadas as intervençóes corais) de pelo menos cinco das tragédias de Eurípides. A. Komornicka ("Hélène de Troie et son 'double' dans la littérature grecque", Euphrosyne 19, 1991, 17-18) faz o inventário detalhado destes passos. 
nunca chegara a embarcar na nau de Páris rumo a Tróia. Ali, um eidolon, fantasma forjado por Hera à sua semelhança, fora o motivo real do conflito que opusera Aqueus e Troianos. Fruto, portanto, da vingança de uma deusa despeitada - a quem Páris não concedera o prémio da beleza -, ou resultado de um desígnio do pai dos deuses, que pretendia aliviar a terra sobrepovoada e glorificar o nome de Aquiles, a longa guerra travada em Ílion via assim reduzida a uma névoa inconsistente e volátil todos os seus fundamentos.

Ora, nesta causa ilusória que Eurípides apresenta para o desastre troiano, vemos alegoricamente espelhada a censura do autor a um inane e já obsoleto ideal de glória guerreira, que, promovido durante séculos pela poesia épico-trágica, viera a repercutir-se na política militarista da Hélade, atirando-a para inúteis e sucessivos confrontos. Mas se o momento presente inspira ao drama um discurso de teor manifestamente anti-belicista, nem por isso o argumento se torna refém de uma circunstância concreta da história da Grécia, móbil apenas para uma reflexão bastante mais ampla do real, que passa pelo repensar da tradição à luz de um novo código ético e de um moderno paradigma epistemológico.

Assim, neste discurso de absolvição de Helena, não deixa de ser evidente a intersecção do legado mitopoiético com as directrizes essenciais do pensamento sofístico: se, por um lado, se representa o poder inelutável dos deuses na condução do destino das personagens, tema bem documentado na poesia épico-trágica, por outro, pondera-se a falácia dos sentidos enquanto obstáculo ao conhecimento absoluto. No mesmo sentido, se uma fidelidade à prova dos anos aproxima Helena da Penélope homérica ${ }^{7}$ este

${ }^{7}$ Os inúmeros pontos de contacto existentes entre as figuras de Helena e Penélope, grande parte dos quais tornados evidentes no monólogo de apresentação da protagonista (o assédio amoroso do pretendente, a que 
modelo de virtude é claramente superado por uma heroína bem contemporânea que trará a cena um novo código de actuação, no qual a arte da palavra é a medida do poder e da excelência.

Numa peça que aos poucos se vai revelando como verdadeira síntese do pensamento - e bem assim da técnica e do estilo - euripidiano, a própria herança mitológica fica à mercê da arrojada criatividade do trágico. Dissolvendo, pois, a aura de sacralidade em que os seus antecessores haviam envolvido o mito, com a mesma irreverência que ecoa nas palavras de Helena quando lhe questiona a veracidade (21), Eurípides ousa submetê-lo às exigências do seu tempo, transfigurando-o, umas vezes, reajustando-o, outras, e quase sempre trazendo para a luz as suas mais inusitadas versôes. Em rigor, não se trata de uma ruptura iconoclasta com a tradição mitopoiética, até porque esta marcará presença constante na peça não só como referencial mas também como elemento de contraste na composição de personagens, espaço e acção. Veja-se, por exemplo, como, numa intriga que retoma o padrão épico do nostos e onde ressoam nítidos ecos da Odisseia ${ }^{8}$, a nova Helena é a imagem invertida da esposa adúltera do mito, ou a velha porteira o reverso da bela e solícita Nausícaa, na hostilidade com que recebe o náufrago Menelau, também ele uma hábil distorção da figura de Ulisses.

A própria escolha do Egipto como cenário do drama, num desvio inesperado à versão tradicional do mito, exemplifica, logo no verso de abertura, o modo como Eurípides, sem nunca

resiste com a perseverança da fidelidade; a espera paciente pela chegada redentora de Menelau; entre outros) são minuciosamente explorados por um amplo número de estudiosos (e.g. I. E. Holmberg, "Euripides' Helen: most noble and most chaste", AJPh 116.1, 1995, passim; G. Meltzer, "Where is the glory of Troy?': Kleos in Euripides' Helen", Class. Antiq., 13 (25), 2, 1994, 243, n.35).

${ }^{8}$ M. F. Silva ("Ecos da Odisseia na Helena de Eurípides", Máthesis 13, 2004, 227-42) faz uma análise meticulosa dos passos onde é sobretudo visível a influência do designado texto homérico nesta tragédia. 
perder de vista a tradição de que é legatário, retoma e reformula os múltiplos dados que vai colhendo em fontes diversas. $\mathrm{Na}$ verdade, se já nos poemas homéricos se encontram alusōes dispersas à passagem de Menelau e da consorte por terras egípcias ${ }^{9}$, é em Heródoto ${ }^{10}$ que Eurípides recolhe matéria para explorar as potencialidades dramáticas de um espaço irremediavelmente conotado com o universo bárbaro.

No entanto, se Homero se ocupa da recriação da atmosfera de grandiosidade e exotismo que o país do Nilo desde sempre inspirara à imaginaçấo grega ${ }^{11}$, Eurípides aproveita o estereótipo de riqueza e ostentação associado ao mundo não helénico para enriquecer o debate em torno da antítese Gregos/Bárbaros ${ }^{12}$, ao

${ }^{9} \mathrm{Na}$ Ilíada (6. 288-92), as vestes sidónias oferecidas por Páris a Hécuba testemunham a visita do príncipe troiano ao país do Nilo, já de regresso a Ílion e na posse de Helena. Contudo, de acordo com o livro III da Odisseia (299-302), é Menelau quem, à vinda de Tróia, acaba por aportar ao Egipto, impelido por uma tempestade. O livro IV (350-480) relata ainda a estada do Atrida na ilha egípcia de Faros, onde recebe a visita de Idótea, filha de Proteu, o Velho dos Mares. Apiedada de Menelau, propóe-se ajudá-lo a ludibriar o pai, que acaba por revelar ao rei de Esparta como obter dos deuses ventos favoráveis. É ainda na Odisseia que surge a única referência à presença de Helena no Egipto, quando se diz ter recebido de Polidamna, mulher do soberano egípcio Tóon, os filtros mágicos (4. 219-26, 227-30) que, em Esparta, adiciona ao vinho de Telémaco e dos demais convivas para mitigar-lhes o sofrimento. Esta passagem é, de resto, referenciada pelo autor do argumento que conservamos da peça ( $v d$.infra).

${ }^{10} \mathrm{Vd}$. Hdt., II, 112-120. Relata o historiador que, no regresso de Páris a Ílion, uma tempestade desvia as suas naus para o Egipto, onde é recebido pelo rei Proteu, que decide reter Helena na intenção de devolvê-la ao esposo ultrajado pelo hóspede troiano. Finda a guerra de Tróia, Menelau constata a verdade das palavras de Príamo, que antes o advertira da ausência de Helena, deixada sob custódia de Proteu. O resgate da heroína no Egipto nem mesmo na versáo de Heródoto dispensa o derramamento de sangue, com Menelau a sacrificar dois jovens egípcios, a fim de obter ventos propícios para a viagem, e a incorrer na fúria vingativa do soberano, que logo ordena a perseguição às naus aqueias.

${ }^{11}$ Esta concepção helénica do Egipto como país de maravilhas e obras de indescritível grandeza encontra-se documentada em Hdt., II, 35.

${ }^{12} \mathrm{O}$ tema é desenvolvido no capítulo 2.3. deste estudo introdutório. 
mesmo tempo que vai moldando o perfil de virtude e inocência da sua protagonista. Distanciando-se da imagem de frivolidade e coquetismo que a caracteriza em tantas outras peças do trágico $^{13}$, a nova Helena prova agora o seu desapego aos bens aparentes, quando prefere regressar a Esparta com Menelau - um naúfrago em trajes andrajosos -, a reinar no faustoso palácio egípcio (430-32), partilhando a lauta mesa do faraó (295-96). Por outro lado, também os especiais poderes de que Helena é investida, em Homero, aquando da passagem pelo Egipto, oferecem a Eurípides profícuo material para a caracterização da sua protagonista. No texto do épico, o efeito apaziguador do discurso de Helena ${ }^{14}$ é garantido pelo poder analgésico de um filtro mágico oferecido à Espartana por uma rainha egípcia. Já em Eurípides, uma hábil administração das palavras revelar-se-á por si só capaz de induzir uma diferente percepção da realidade no espírito daqueles a quem são dirigidas, sobrepondo-se mesmo às divinas artes proféticas da filha do faraó. Feiticeira, na versão mais fantasista de Homero, ou artífice da palavra, como a representa o trágico ateniense, Helena mostra-se igualmente capaz de mudar disposiçôes, manipular a emoção, criar nos espíritos cenários ilusórios de vida e de morte. E a poesia faz-se assim representar, no drama de Eurípides, como lenitivo para as dores presentes do seu público, que na palavra encontra, tal

${ }^{13}$ M. F Silva ("Helena, um exemplo de futilidade feminina e de snobismo bárbaro", O mito de Helena: de Tróia à actualidade, vol. I, Coimbra, 2007, passim) identifica e analisa com grande detalhe os passos euripidianos em que é especialmente expressiva esta representação de Helena como mulher vaidosa e fútil, afeita ao luxo e à ostentação, não muito distante da heroína dos poemas homéricos, que surge invariavelmente enquadrada em ambientes de riqueza exuberante. Emblemática, neste sentido, é a censura que Hécuba, nas Troianas (991-97, 1020-21), dirige à rainha de Esparta, a quem acusa de se haver deixado seduzir pelas sumptuosas vestes de Páris e pelas afamadas riquezas de Ílion, causando a ruína de duas naçóes.

${ }^{14}$ Vd. supra n. XXX 
como a própria protagonista, um eficaz meio de catarse ou de evasão.

Já as similitudes entre a versão de Heródoto e a do tragediógrafo não se definem a este nível de subtileza, o que se deve naturalmente à maior objectividade do relato historiográfico, purgado de elementos fantásticos e sugestôes metafóricas. As coincidências são, de facto, evidentes e imediatas: o Egipto é, em ambos os textos, o espaço que acolhe Helena durante os anos do cerco de Tróia e Proteu o rei virtuoso que a livra da desonra e lhe oferece generosa hospitalidade até à chegada Menelau. Em Eurípides, como antes em Heródoto, o país do Nilo será ainda local de passagem para o Atrida, aquando do regresso à pátria, do mesmo modo que o derramamento de sangue egípcio, claro desrespeito pelos sagrados deveres do hóspede, a forma encontrada por Menelau para seguir viagem com a esposa rumo a Esparta. Nesta coincidência de dados, duas são as ideias que prevalecem: a da inutilidade da guerra de Tróia e a da inversão dos pólos da antinomia Gregos/Bárbaros. Apenas num ponto o relato de Heródoto se mostra incapaz de servir o propósito de Eurípides: sem efectivamente inocentar Helena, que na nau de Páris havia embarcado para Ílion, Heródoto atribui a circunstâncias alheias à vontade da Espartana ${ }^{15}$ - uma tempestade e a intervenção de Proteu - o facto de jamais ter aportado a Tróia.

A reabilitação de Helena exige, pois, de Eurípides novas soluções, que não passam pela mera reposição do já conhecido repertório de argumentos de defesa da heroína, bebidos na poesia épica e abrilhantados segundo as técnicas e subtilezas

${ }^{15}$ Segundo C. Soares ("Rapto e resgate de Helena nas Histórias de Heródoto", O mito de Helena: de Tróia à actualidade, vol. I, Coimbra, 2007, 84), Helena assume um papel claramente passivo nos acontecimentos relatados por Heródoto, em cuja versáo se confia a Páris, Menelau e Proteu a condução do destino da Espartana. 
da retórica sofística ${ }^{16}$. É bem certo que o trágico não hesita em colocar na boca da sua nova Helena as escusas já advogadas na epopeia homérica e repetidas, com variaçôes mais ou menos acentuadas, na produção poética subsequente: as culpas partilhadas por Páris (233-35) e Afrodite (236-37, 1097-99) $)^{17}$ - a que se soma agora a intervençáo de Hera (31-34) -, dando cumprimento a um plano superior traçado por Zeus $(36-41)^{18}$, vêm mais uma vez aligeirar o ónus da responsabilidade da protagonista, ainda que náo tenham força bastante para sustentar o seu renovado perfil de virtude e castidade. Para conferir-lhe consistência, impõe-se, antes de mais, atribuir a um deus o rapto da bela - poderia Helena opor resistência ao plano de Páris, mas nunca ao de Hermes; forjar-lhe, entre a realeza egípcia, um pretendente tenaz; garantir-lhe o favor da sábia profetisa, templo vivo da justiça; encontrar, enfim, distinto culpado para o desastre troiano, imputando a uma outra Helena os ódios antigos.

Apesar de alheios à versão tradicional do mito, em cada um destes novos elementos, ressoam, como antes se disse, ecos da antiga herança literária que o trágico adaptou às exigências da intriga. Afinal, na soma das suas diversas versôes, o mito de Helena acabou por afirmar-se, já na tradição, indissociável do

${ }^{16}$ Uma sofisticada retórica de auto-defesa, que chega mesmo a complementar as razóes homéricas com subtis argumentos de probabilidade, já havia sido ensaiada pelo trágico nas Troianas, 914 sqq. (sobre o uso que faz Eurípides desta técnica sofística na construção da rhesis de Helena em Tr., vd. D. J. Conacher, Euripides and the Sophists, London, 1998, 54). Para mais, depois de conhecido o Elogio de Helena, da autoria do sofista Górgias, qualquer discurso reincidindo numa justificação da Espartana perderia todo o direito à qualificação de 'inovador.'

${ }^{17} \mathrm{Na}$ Ilíada (3. 383-420), após o confronto de Páris com Menelau, é Afrodite quem constrange Helena a visitar o leito do príncipe troiano. A responsabilidade da deusa é também sugerida em Od.4. 260-64.

${ }^{18}$ Cf. Hom., Il., 1. 5. 
motivo do rapto e a novidade aqui introduzida, o arrebatamento da protagonista pelo deus Hermes - decalcado da cena do rapto de Perséfone -, vem apenas repetir um padrão poético convencional ${ }^{19}$ bem familiar ao público da tragédia. De modo semelhante, a perseguição amorosa movida a Helena por Teoclímeno transporta a heroína para um cenário e condição de suplicante não menos conhecidos do espectador, que vê, assim, reproduzido a contraluz, o quadro da perseverança e fidelidade da rainha de Ítaca, em espera paciente pela chegada do marido. E mesmo a intervenção da princesa bárbara, árbitro de um conflito entre deusas no qual se joga o futuro de Helena, não só evoca o julgamento do Ida, como retoma uma visão estereotipada do mundo egípcio, que a literatura se inclinou a representar como lugar místico de transcendência e profecia. ${ }^{20}$

A relação intertextual ultrapassa, deste modo, o nível da orientação e temas gerais da peça, expressando-se cenicamente em movimentos, gestos e quadros, que dão afinal novo fôlego a um bem conhecido código de convençôes cénicas e literárias ou reinventam episódios célebres de um património secular. Em suma, sem nunca colar-se aos modelos da tradiçấo, o tragediógrafo mescla diferentes referências históricas e literárias em função dos seus propósitos dramáticos, ou desloca-as simplesmente

${ }^{19}$ Obedecendo, de facto, a um padrăo bastante comum na mitologia, a cena de rapto de uma jovem por um deus em cenário bucólico converteu-se num isótopo da poesia grega, particularmente da épica (cf. C. A. Sowa, Traditional themes and the Homeric Hymns, Chicago, 1984, 135-44). D. Juffras ("Helen and other victims in Euripides' Helen ", Hermes 121.1, 1993, 47-48) enumera uma série de exemplos de episódios mitológicos que comprovam a existência de um conjunto de elementos comuns no quadro de abduçáo, destacando ainda o papel de Hermes numa variante específica desta cena-tipo.

${ }^{20}$ Vd. W. Allan, Euripides. Helen, Cambridge, 2008, 28, n.128. O próprio Heródoto (II, 82-83) dá voz a esta representação do povo egípcio, que associa, sobre qualquer outro, às práticas proféticas e divinatórias. 
do seu contexto habitual, conferindo-lhes, assim, a aparência de uma completa novidade ${ }^{21}$.

Apenas a recriação do motivo do eidolon, agora ao serviço de uma mensagem pacifista ou de um debate de natureza epistemológica forjado segundo o modelo sofístico, poderia ter causado o impacto de uma verdadeira inovaçấo. ${ }^{22}$ Ainda assim, o fantasma de Helena não chega a ser uma criação do trágico ateniense. Entre os estudiosos, disputa-se a autoria do motivo, que alguns afirmam remontar a Hesíodo ${ }^{23}$, embora a opinião prevalecente o atribua a Estesícoro. ${ }^{24}$ Da biografia deste poeta do séc. VI a. C., natural de Hímera, na Sicília, pouco se conhece além de uma antiga lenda segundo a qual, para recobrar a visão ${ }^{25}$, que lhe retirara

${ }^{21}$ W. Allan (op.cit., 26-27) interpreta sob um diferente ângulo o modo como Eurípides reelabora o material da tradição, ao afirmar que a sua técnica consiste, inversamente, em dar ao que é novo um rosto antigo e convencional. Segundo o autor, "he puts a non-Homeric - and even anti-Homeric - episode in Homeric clothes".

${ }^{22}$ Embora os vv. 1280-83 da Electra, apresentada um ano antes, houvessem já anunciado, em linhas gerais, aqueles que viriam a ser os tópicos nucleares do argumento da Helena, o público ateniense náo poderia ter antecipado aquela que era já a intençáo de Eurípides, a partir desta vaga referência a uma versão marginal do mito.

${ }^{23}$ E. g. J. Assaël ("Les transformations du mythe dans l'Hélène d'Euripide", Pallas 33, 1987, 52, n. 7) e A López Eire ("Un mito de la retórica de Górgias", O mito de Helena: de Tróia à actualidade, vol. I, Coimbra, 2007, 228). Esta tese encontra o seu fundamento num escólio a um verso de Licofronte, onde se atribui a Hesíodo (fr. $358 \mathrm{M}-\mathrm{W}$ ) o tema do fantasma etéreo que toma o lugar da verdadeira Helena.

${ }^{24}$ E.g. D. J. Conacher (Euripidean Drama - Mith, theme and structure, Toronto, 1967, 288), A. M. Komornicka (op. cit., 15), J. Romilly ("La belle Hélène et l'évolution de la tragédie grecque", $L E C 56,1988,138$ ). Ressalve-se, no entanto, que o tópico do fantasma, embora sem relação particular com a personagem de Helena, náo era de todo desconhecido na literatura grega. Já na Ilíada (5. 449-51), Eneias é salvo graças à intervenção do deus Apolo, que forja um eidolon idêntico ao herói para confundir o seu inimigo.

${ }^{25}$ De acordo com R. Scodel (apud E. Suárez de la Torre, "Helena, de la épica a la lírica griega arcaica: Safo, Alceo, Estesícoro", O mito de Helena: de Tróia à actualidade, vol. I, Coimbra, 2007, 68), a rectificação apresentada 
Afrodite por haver vituperado Helena num dos seus poemas, Estesícoro compóe uma palinódia ${ }^{26}$ onde retracta moralmente a heroína. Deste poema, chegou até nós um exíguo fragmento, citado por Platão no $\mathrm{Fedro}^{27}$ : «Não é verdade esta história./ Não embarcaste nas naus de sólidos bancos. / Não foste à fortaleza de Tróia.». Também na República, ${ }^{28}$ o filósofo inclui uma alusão à palinódia, de acordo com a qual, «na ignorância da verdade», Gregos e Troianos haviam pelejado não por Helena, mas por um eidolon, na aparência idêntico à Espartana.

Ora, se nem mesmo o fantasma da heroína configura, por si só, uma novidade absoluta no panorama da literatura grega, o que existe de verdadeiramente original nesta tragédia de Eurípides? D. J. Conacher e A. M. Komornickaa ${ }^{29}$ são unânimes em apontar a nova Helena como fulcro da originalidade da peça. Esta posição, defendida, de forma mais ou menos explícita por um considerável número de estudiosos, dificilmente pode ser

por Estesícoro, pelo seu carácter radicalmente inovador, exigiria uma justificação em conformidade, que apenas um relato lendário, no que tem de espectacularidade, poderia assegurar. Da lenda atinente à cegueira de Estesícoro, sumaria Suárez de la Torre (ibid., 68) as diferenças entre as três variantes conhecidas, atribuídas a Cónon, Hérmias e Pausânias.

${ }^{26}$ Alguns estudiosos, entre os quais C. Bowra (1963), M. Doria (1963) e F. Sisti (1965), defendem a existência de uma segunda palinódia. A tese surge na sequência da edição de Page do P. Oxy. 2506, datada de 1962, que traz à luz um fragmento do peripatético Camaleonte de Heracleia. Segundo este, Estesícoro teria composto não uma, mas duas palinódias, a primeira das quais censurando Homero por haver omitido o fantasma de Helena, a segunda dirigindo a Hesíodo uma crítica, para a qual não apresenta razão. Náo cabe, contudo, no propósito deste estudo introdutório, escalpelizar os argumentos relativos à existência de duas palinódias, por não condicionarem a interpretaçấo do texto euripidiano.

${ }^{27} \mathrm{Pl} .$, Phdr., $243 \mathrm{~A}$.

${ }^{28} \mathrm{Pl}$., R. IX, 586 B-C. A referida alusão ao eidolon pretende ilustrar, no texto platónico, a enganadora seduçáo exercida pelas aparências e o carácter ilusório da beleza, duas questóes que perpassam todo o argumento da Helena.

${ }^{29}$ Vd. D.J. Conacher (op. cit., 289) e A. M. Komornicka (op. cit.,15). 
desmentida, embora os argumentos que a sustentam tendam a ser, de uma forma geral, frouxos ou insuficientes.

Antes de mais, o que distingue a protagonista da tragédia de 412 a.C. não é a absolvição que a peça para ela reclama; afinal, a defesa de Helena, ensaiada poucos anos antes por Górgias na forma de uma antilogia bem ao gosto da Sofística ${ }^{30}$, tivera já representação durante o período arcaico, na lírica de $S_{a f o}{ }^{31} \mathrm{e}$ $\mathrm{Alceu}^{32}$, já para não mencionar a principal fonte euripidiana, o poeta Estesícoro.

Não se veja também na duplicidade da figura de Helena a grande inovação desta peça de Eurípides. Materializando-se aqui numa oposição concreta entre a mulher real e o seu espectro, a ambiguidade que rodeia a protagonista, com raízes profundas na tradição literária, remontaria já à poesia épica. Em Homero, o discurso de acusação de Helena, causa de uma guerra devastadora $^{33}$, segue a par, como antes se disse, com a retórica de desculpabilização da heroína, frequentemente apresentada como rosto de um conflito desencadeado por obra e determinação dos deuses mais do que pela sua natureza perversa. Lembre-se que Príamo, na Ilíada (3. 164-65), como, na Odisseia, Telémaco (17.

${ }^{30}$ No seu Elogio de Helena, Górgias (fr. B10 D-K) constrói a defesa de Helena sobre três motivos justificativos do seu acto. De acordo com a argumentação desenvolvida nesta antilogia, à Espartana não poderia ser imputada qualquer responsabilidade pelo resultado da sua natural submissão à inexorabilidade do destino e da vontade divina, ao poder superior do discurso eloquente, ou mesmo à força invencível do amor despoletado pela visão do belo.

${ }^{31}$ Demarcando-se da tradição, Safo desculpabiliza a Espartana ao apresentar a sua fuga com Páris como obra de um amor inelutável, que a contemplação da beleza excepcional induz ( $v d$. Sapph., fr. 16 L-P).

${ }^{32}$ Embora na poesia de Alceu esteja também representada a versão do mito que a épica consagrou ( $v d$. fr. 42), não podemos deixar de salientar o toque de inovaçáo que merece o tratamento da figura de Helena no fr. 283, onde, subjugada pela mania amorosa e de certa forma destituída de sentido racional, surge como vítima dos ditames de Eros.

${ }^{33}$ E.g. Il., 2.160. 
119) e Penélope (23. 218-224), ilustres vítimas da sangrenta guerra travada em nome de Helena, são eles mesmos voz deste discurso de condescendência, onde apenas há lugar à justificação da personagem. Posição inversa coexiste, em ambos os poemas, com tal visão benevolente da Espartana e os exemplos podem, mais uma vez, achar-se nos dois lados do campo de batalha. Desfavoráveis à rainha de Esparta são, na Ilíada, as palavras dos anciãos troianos, que, na beleza desta mulher, vêem motivo fútil para a ruína do seu povo (3. 154-64). Mas a sombra de perfídia da protagonista assoma sobretudo no ardil tentado em Tróia contra o exército aqueu que adivinhou escondido no bojo do célebre cavalo de madeira, de acordo com o relato do próprio Menelau $^{34}$. A réplica à acusação dá-la-á, no entanto, a própria Helena quando lembra o banho lustral com que em Tróia retribuíra a Ulisses o estatuto de herói e a promessa cumprida de não revelar a sua presença na cidade inimiga, onde penetrara furtivamente sob o disfarce de mendigo. Porém, a afirmação de pró-helenismo em que se funda a auto-defesa de Helena apenas contrabalança, num equilíbrio sempre favorável à ambiguidade, com o seu lamento pelo abandono do lar e dos entes queridos ${ }^{35} \mathrm{e}$ com um sentido de culpa que a leva a apelidar-se a si mesma de 'cadela'. ${ }^{36}$ Nesta mesma linha de duplicidade, também a heroína de Eurípides alterna entre a defesa afincada da sua inocência (42-43, 270-72, 582) e o lamento compungido pelo desastre causado em Tróia (198-99, 383-85), entre a busca obstinada do bom nome maculado (929-32) e o pesar pela desgraça a que o onoma, vazia aparência, conduzira o seu (200-207, 280-85,

${ }^{34}$ Rodeando o cavalo, Helena teria imitado as vozes e apelos das suas esposas, na tentativa de desmantelar o embuste de Ulisses e impedir a tomada de Ílion (Il. 4. 272-79).

${ }^{35}$ Cf. Il. 2. 355-56, 3. 139-40, 3.172-76, 6. 357-58; Od. 4. 259-54.

${ }^{36} \mathrm{Vd}$. Il. 6. 344, 356. 
686-90) e tantos outros lares (364-74). De modo semelhante, o discurso condenatório proferido por Teucro (72-74) é compensado pelo pedido de desculpa que, mesmo inadvertidamente, endereça à protagonista (80-82), assim como a responsabilidade que o servo de Menelau imputa a Helena $(619-21,703)$ terá o seu contraponto nas palavras da sábia Teónoe, quando confirma a mentira na origem da guerra (880-83).

Ora, se não é na defesa intransigente da virtude de Helena ou sequer na ambiguidade da personagem que reside o carácter original da peça, seria lógico concluir que a inovaçáo resulta de um abandono definitivo do perfil de crueldade, ambição desmedida e aleivosia que a tragédia clássica colara ao nome de Helena. Mais uma vez, no entanto, não é possível afirmar que a heroína retractada se afasta radicalmente da personagem criada por Ésquilo, a quem a literatura grega ficou a dever uma verdadeira "diabolização" da Espartana ${ }^{37}$. Deste discurso condenatório de Helena, encontraremos em Teucro o mais evidente representante: no ódio que lhe merece a rainha de Esparta, a «sanguinária» a quem atribui a culpa pela desgraça de todos os Aqueus, percebemos ecos bem nítidos do Agamémnon esquiliano, ou evocamos a virulência da acusaçáo proferida por Hécuba, nas Troianas ${ }^{38}$, talvez o exemplo mais expressivo do retrato negativo que o próprio Eurípides traça de Helena em algumas das suas obras, entre as quais Andrómaca, Hécuba ou Orestes. De resto, é precisamente no confronto com o guerreiro aqueu que Helena começa por evidenciar alguns dos traços menos positivos do seu carácter: preocupada apenas com a sua segurança, vemo-la desconsiderar

${ }^{37}$ Vd. A., Ag., 62 sqq, 226, 404 sqq., 727 sqq., 745 sqq., 1455 sqq.. Ao contrário do que se verifica na poesia de Homero e nas tragédias euripidianas que exploram o mito de Tróia, no Agamémnon de Ésquilo não há lugar ao mais pequeno laivo de ambiguidade na caracterizaçáo de Helena, sob a qual impende total responsabilidade pelas desgraças decorrentes da guerra.

${ }^{38}$ Eur., Tr., 969 sqq.. 
egoisticamente o propósito que levara Teucro a terras egípcias e desprezar, assim, aquela que é, em toda a peça, a sua única oportunidade de compensar uma das vítimas do engano gerado em torno do seu nome. Ao invés de dar ao companheiro grego a orientação de que precisa para prosseguir viagem, a heroína manipula todo o diálogo no sentido de obter dele a informação de que necessita para ponderar as possibilidades do seu próprio regresso. E é precisamente no momento do regresso que a crueldade da Espartana volta a emergir na sua expressão máxima: a mesma Helena que se penitenciara, compassiva e solidária, pelas mortes causadas por um nome vazio, é quem, movida por um não menos inane desejo de glória, incitará impiedosamente ao derramamento de sangue bárbaro.

No fundo, resultado de uma síntese perfeita dos traços recolhidos tanto na poesia épica como na lírica ${ }^{39}$, na tragédia como na retórica sofística, é a densidade psicológica da protagonista que começa por distingui-la de uma vastíssima galeria literária de Helenas, ora culpadas mas penitentes, ora insidiosas e adúlteras, que o próprio Eurípides explorara já amplamente ${ }^{40}$. E de forma quase paradoxal, ao mesmo tempo que modela a psicologia da sua personagem, insuflando no modelo mítico realismo e humanidade, Eurípides não só conserva como reforça a sua função simbólica. À mulher dos espelhos, tal como surge

${ }^{39}$ E. Suárez de la Torre (op. cit., 55) faz um inventário bastante completo dos poetas líricos que afloraram o tema de Helena: Alceu, Safo, Teógnis, Álcman, Estesícoro, Î́bico, Simónides e Píndaro. À excepção do que se verifica na poesia de Alceu, Safo e Estesícoro, que, como antes se disse, apresentam um tratamento algo inovador da personagem mítica, a imagem da Espartana traçada pelos líricos não representa senão uma continuidade daquela que a épica cristalizara. Segundo o autor, causa imediata da guerra, Helena não é aqui, como em Homero, a sua derradeira responsável, com Afrodite (Ibyc., S151, 9), Eros (Thgn., 1232) ou a ananke (Pi., Pae. 6, 95-98) a determinarem, em última análise, o conflito e a ruína de Tróia.

${ }^{40}$ Vd. infra p. 25 n. 52. 
frequentemente representada na literatura e nas artes plásticas, ${ }^{41}$ é dado agora reflectir a dualidade do(s) ser(es) e demonstrar o carácter ilusório dos bens aparentes.

Em suma, náo é o elogio de Helena nem uma qualquer paródia da sua defesa que Eurípides ensaia nesta tragédia e tâo pouco o faz à custa de uma leviana desconstrução das bases seculares do mito. Ao desvinculá-lo antes do critério de veracidade, destacando-lhe a natureza retórica e simbólica que desde sempre lhe presidira mas que o influxo da sofística viera colocar em evidência ${ }^{42}$, a Helena - peça e personagem de Eurípides - assume-se, afinal, como tese da natureza intrinsecamente contraditória do real, numa autêntica celebração do poder efectivo da palavra (onoma-logos-mythos) num mundo dominado pela opinião $($ doxa $)$.

${ }^{41}$ Tal como observa M. F. Silva, op. cit. 2007, 100, «os espelhos tornaram-se uma espécie de insígnia da bela espartana», a atestar pela cópia de passos literários em que o objecto materializa a vaidade e coquetismo de Helena (e.g. E. Or. 1112; Tr. 1106-1109; Hec. 925). A respeito da representação plástica do espelho enquanto objecto emblemático da heroína, a autora (ibid., n. 22) remete para LIMC IV, 71, 72, 81, 86, 102, 103.

${ }^{42}$ Segundo A. López Eire (op. cit., 2007, 216-18), ficou a dever-se aos sofistas, em particular a Protágoras e a Górgias, esta exploração da vertente simbólica e retórica do mito. Alheio ao conceito de veracidade, o discurso mitológico teria por função induzir no receptor, geralmente uma comunidade social que partilha um certo número de códigos, determinada opiniáo (doxa) sobre um qualquer assunto ou realidade. 


\section{Helena, uma peÇA de Antíteses.}

\subsection{A MOLDURA SOFÍSTICA DO ARGUMENTO}

Afirma Jacqueline de Romilly que o teatro de Eurípides, «longe de se ater a uma permanente busca do patético, substitui muitas vezes o espectáculo do sofrimento por uma argumentação intelectual a respeito dos temas da moda». ${ }^{43}$ Desta face inovadora da produção euripidiana é a Helena cabal exemplo. Ao dar contorno dramático a algumas das mais vivas polémicas que convulsionavam o meio intelectual ateniense, Eurípides faz derivar do debate ideológico toda a uis tragica desta peça, cujo argumento se constrói sobre as permanentes tensóes geradas em torno de um conjunto de conceitos dicotómicos, de matriz sofística. Antíteses como verdade/aparência, onoma/pragma, opinião/conhecimento, razão/sensação, corpo/espírito, morte/vida, necessidade/livre arbítrio, culpa/inocência ou mesmo cultura grega/barbárie alinham, pois, com o recorte romanesco de uma tragédia onde se sucedem encontros e desencontros, enganos e revelaçôes, desaires e vitórias. Por outro lado, nos diversos matizes que estas antinomias vão assumindo, não é difícil entrever os tópicos que viriam a dominar a discussão platónico-sofística em torno do valor da retórica ou da própria poesia, e do lugar por estas ocupado numa sociedade onde a virtude guerreira perdia, a cada passo, destaque face à progressiva afirmação do poder da palavra.

Se começarmos por considerar a versão do mito adoptada por Eurípides nesta tragédia, perceberemos que nela é, de facto, possível projectar grande parte dos temas que ocuparam pensadores tão eminentes como Górgias, Protágoras, Pródico ou Antifonte e, anos mais tarde, o próprio Platão.

${ }^{43}$ Cf. J. Romilly, La modernité d'Euripide, Paris, 1986, 117. 
Desde logo, a dicotomia que se estabelece entre a verdadeira Helena, esposa casta e fiel, e o seu fantasma, a etérea ilusão que, forjada por Hera, viria a estar na origem da ruinosa Guerra de Tróia, configura, por si só, o insanável conflito entre os termos aletheia (verdade) e dokesis (aparência), tema estruturante na ideologia sofística, no qual radicam náo só os fundamentos do relativismo gnoseológico de Protágoras, o sofista que concebia a verdade como construção subjectiva ${ }^{44}$, mas também os princípios do cepticismo de Górgias, para quem náo existia outra forma de conhecimento além da opinião (doxa).

Por outro lado, ao colocar em confronto duas versóes opostas do mito de Tróia, Eurípides estaria a dar forma dramática à teoria sofística dos dissoi logoi, segundo a qual toda a realidade admite uma dupla perspectiva e bem assim dois discursos antagónicos ${ }^{45}$. Atribuído a Protágoras, este método não só implica a negação do carácter absoluto da verdade, sujeita às modulaçôes da percepção individual $^{46}$, como demonstra a descontinuidade existente entre 'palavra' (onoma) e 'ser' (pragma), um tema que concitou o interesse dos mais insignes nomes da sofística na Atenas do século V a.C.. O mesmo Protágoras ter-lhe-ia inclusive dedicado um tratado com o título Orthotes onomaton (à letra, "propriedade dos nomes" $)^{47}$, onde discutiria a relação natural ou convencional entre as palavras e os seus referentes directos. Desta questáo se ocupou também Pródico ${ }^{48}$ que, tornado célebre pelos seus estudos a respeito de sinonímia, se dedicava a encontrar, para cada

${ }^{44}$ Cf., Protag., A13, A21 D-K.

${ }^{45}$ Cf. Protag., A20, B 6 a, C2 D-K.

${ }^{46}$ Cf. Protag., B1 D-K, a respeito da célebre teoria do homem-medida, cuja interpretação gerou grande controvérsia entre autores antigos e modernos.

${ }^{47}$ É Platão quem, no Crátilo (passim), dá testemunho do interesse que a questáo mereceu por parte dos sofistas Protágoras e Pródico, interesse este também documentado no Fedro (266d sqq.), onde Sócrates atribui ao pensador de Abdera uma obra com o mesmo título.

${ }^{48}$ Cf. Pl., Cra., 384 b. 
termo, diferente equivalente no mundo real ${ }^{49}$, na tentativa de provar a capacidade da linguagem para transmitir a verdade dos seres. Distinta é a abordagem de Górgias. No seu tratado Do não ser, o sofista defende a não identificação do signo com a realidade representada ${ }^{50}$, donde parte para a afirmação da natureza incognoscível - ou, pelo menos, incomunicável - da verdade: «Nada existe, mas, mesmo que existisse, não seria cognoscível e, ainda que o fosse, não poderia ser comunicado a outrem. »1 $^{5}$. Ora, à Helena de Eurípides não é também alheia a questáo do valor arbitrário da linguagem, que percebemos implicada neste conhecido postulado do sábio de Leontinos. Afinal, a própria acçấo da peça progride no sentido da reabilitação da imerecida fama da Tindárida - mulher de nome maldito, porém de irrepreensível conduta -, tornando paulatinamente patentes aos olhos do espectador as oposiçóes que se estabelecem entre 'nome' e 'acçáo' (onomal pragma) ou 'discurso' e 'verdade' (logos/aletheia). A aporia do conhecimento torna-se, contudo, cada vez mais evidente à medida que percebemos que a via tentada para a reposiçấo da verdade não é senão a própria palavra. Obstinada em provar que o nome infame que a tradição lhe legara mente afinal sobre o seu verdadeiro destino, a protagonista náo hesitará em recorrer aos artifícios da retórica, chave do êxito que a veremos alcançar não só no diálogo travado com Teucro, mas sobretudo em momentos decisivos como a súplica a Teónoe ou o logro de Teoclímeno. E se consegue persuadir, um após outro, os seus interlocutores, garantindo assim a sua salvação física e moral, fá-lo a heroína urdindo uma teia de sucessivas ilusóes, em que a verosimilhança se

${ }^{49}$ Cf. Pl., Prt. 337 a-c, 340 a-b.

${ }^{50} \mathrm{Vd}$. Gorg, fr. B3. 84: «Na verdade, é com a palavra que identificamos algo, mas a palavra náo é nem aquilo que está à vista nem o ser: logo, aos que nos rodeiam, náo comunicamos o ser, mas sim a palavra, que é diferente das coisas visíveis.»

${ }^{51}$ Cf. Gorg., fr. B3. 65, 77, 83 D-K. 
substitui à verdade. A eloquência ${ }^{52}$ revela-se, desta feita, veículo privilegiado da apate (ilusão), ao lado da tragédia, que Górgias sugere tratar-se de retórica em forma de verso ${ }^{53}$. Porém, se, por um lado, a define como arte do engano, por outro, assegura o sofista que, tal como na poesia, a ilusão veiculada pela retórica pode ser colocada ao serviço de uma causa justa e tornar até mais sábia a própria vítima deste engano. ${ }^{54}$ É neste contexto que o espectador de Eurípides, colocado no centro da polémica que viria a opor Platão aos mestres da sofística, se vê compelido a reflectir sobre o lugar da retórica e mesmo da poesia na sociedade coeva. Serão elas meros simulacros da verdade, ${ }^{55}$ como afirmará o fundador da Academia, ou, pelo contrário, meios eficazes de alcançá-la? E comportarão maiores benefícios ou prejuízos para os cidadãos? Sem solucionar de forma inequívoca estas questóes, a actuação da Espartana vem, contudo, demonstrar, em abono das teses sofísticas, o poder inelutável do discurso, «senhor soberano» - escreve Górgias, no Encómio de Helena - «capaz de, com um corpo diminuto e quase imperceptível, levar a cabo acçôes divinas». ${ }^{56}$ Insuflar nos espíritos a crença será, pois, o objectivo da protagonista, que no decurso da peça veremos perseguir, de preferência à verdade, o credível, o plausível (eikota), ciente de que, num mundo regido pelas aparências, a realidade não possui força bastante para sobrepor-se à ilusão.

Mas se estas questóes de natureza epistemológica, com as suas naturais implicaçôes morais e até políticas, assumem um

${ }^{52}$ Sobre as múltiplas impressóes que o discurso persuasivo pode induzir no espírito do homem, vd. Gorg., fr.B 10.13 D-K.

${ }^{53}$ Cf. Gorg, fr. B23 D-K.

${ }^{54}$ Vd. supra n. 50.

${ }^{55} \mathrm{Vd}$. Pl. Grg., 463d, onde a retórica é apresentada como simulacro de uma parte da Política, negando-se-lhe o estatuto de ciência. Ainda sobre a retórica como arte da persuasão, assente na crença e não na ciência, $v d$. 454 e 455 a.

${ }^{56}$ Cf. Gorg., Hel., fr. B10. 8. 
lugar de relevo em toda a dinâmica da peça, não é menor a expressáo que têm os temas de natureza social, de novo formulados segundo um modelo antinómico de filiação sofística. De facto, a delimitação das fronteiras que aproximam e separam os termos 'grego' e 'bárbaro', 'escravo' e 'homem livre', 'rei' e 'mendigo', 'fama' e 'anonimato', far-se-á no texto de Eurípides sob influência do pensamento de Hípias ${ }^{57}$ e Antifonte ${ }^{58}$ a respeito da oposição nomos/physis. Ora, tal como a aparência enganadora se opóe à verdade do ser, também o estatuto, o nome, a proveniência das personagens, valores puramente convencionais, porque forjados sob a artificialidade de um acordo social, vêm a revelar-se contrários aos imperativos da natureza, necessários e incontornáveis como a vida ou a morte. Assim, na ironia que faz de um homem anónimo núncio de uma verdade encoberta pelos deuses (605-15); na magnanimidade de uma bárbara que arrisca a vida pela de outros, sacrificando a lei à verdade (1000 sqq.); na crueldade dos soberanos gregos que com a morte buscam conquistar o reconhecimento na pátria (1602 sqq.); e finalmente no contraste do tirano ímpio com o servo leal (1627-41), o argumento vai repondo equilíbrios e desmontando preconceitos, numa afirmaçáo da igualdade dos homens e da superioridade da natureza face à lei.

${ }^{57}$ No Protágoras (vd. Pl., Pro., 337c), Hípias disserta a respeito da antinomia nomos/physis, afirmando a igualdade dos homens perante a natureza e o carácter artificial da lei, que, qual tirano, procura impor-lhe os seus ditames.

${ }^{58}$ Do sofista Antifonte são bem conhecidas as teses relativas à superioridade da physis sobre o nomos. Afirmando o carácter necessário dos imperativos da natureza, tais como viver e morrer, que as disposiçóes da lei, meramente convencionais, não devem contrariar ( $v d$. fr. B44 a D-K), o pensador ateniense defende a igualdade natural de todos homens que, Gregos ou Bárbaros, se encontram irmanados por um conjunto de semelhanças evidentes, prova de uma natureza comum: «Todos nós respiramos o mesmo ar com as nossas narinas" (fr. B44 b D-K). 
Em suma, lançando mão de um artificiosismo retórico e de uma finura dialéctica bem característicos do discurso sofístico, que sabemos ter tido apreciável expressão no conjunto da obra euripidiana, o trágico ateniense entretece no drama uma intrincada rede de conflitos que tocam transversalmente questóes de índole ontológica e epistemológica, socio-política e moral. E todo este jogo de antíteses parece, enfim, congraçar-se com a dualidade que rodeia a figura mítica de Helena, símbolo perfeito do «carácter enigmático do real».59

\subsection{Verdade-aparência: uma Helena 're-tratada'}

Coro: Todas as certezas podem revelar-se falsidades.

Helena: E podem, inversamente, revelar-se verdadeiras. (309-310)

No talhe proverbial dos dois versos transcritos encontramos aquela que seria talvez a epígrafe mais ajustada à Helena de Eurípides, uma tragédia onde verdade e aparência ora se opóem ora se confundem, num jogo de extasiantes efeitos dramáticos que vão reduzindo todas as certezas do público a uma colecção de frágeis opinióes, prontas a caírem ante a força de novas e inesperadas evidências. Nenhuma expectativa pode, de resto, esperar confirmação numa peça em que os protagonistas começam por negar a aparência que lhes obscurece o ser, para terminarem manipulando a imagem em busca de uma glória que, de novo, se sobrepóe à essência. E nenhuma lógica que não a da contradição pode vigorar quando o objectivo dos heróis - repor a verdade e reaver uma vida adiada - implica alimentar ilusóes e percorrer o trilho da morte.

${ }^{59}$ A expressão é de C. Segal, "Les deux mondes de l'Hélène d'Euripide", REG 85, 1972, 296. 
De facto, na Atenas democrática do século $\mathrm{V}$ a. $\mathrm{C}$, onde o ser social se sobrepõe ao individual, são o nome, o estatuto, a fama - a palavra, em suma, mais do que a acção concreta e real - que determinam a integração ou a exclusão, a aceitação ou a rejeição ${ }^{60}$, o poder ou a submissão, termos que passam a definir um novo estado de vida ou morte. Assim se explica o objectivo comum dos heróis gregos cujos caminhos se cruzam nas planícies egípcias: distantes da polis, que lhes confere e assegura a identidade, todos eles almejam reabilitar o nome (onoma) ilustre do passado e as honras de que os priva a sua condição de anonimato em terras bárbaras. Renegada pelos compatriotas e vítima de uma fama injusta, a própria Helena persegue o brilho da glória, mesmo quando rejeita o estigma atribuído ao nome, que diz configurar o engano e a ilusão: «Na verdade, não fui eu a causa da guerra de Tróia ou o prémio da lança helénica, mas o meu nome.» (42-43). Este propósito partilham-no Teucro e Menelau, ambos regressados de um cenário de morte e devastação, com o propósito comum de retomar a vida suspensa durante os dez anos da guerra. ${ }^{61}$ Refundar ou regressar à pátria torna-se, deste modo, um projecto simbólico, muito próximo de uma ressurreição.

É, desde logo, no prólogo da peça que começam a esboçar-se os contornos deste estreito diálogo estabelecido entre morte/

${ }^{60} \mathrm{Na}$ Atenas do século $\mathrm{V}$ a.C., o nome (com a informação que comporta relativamente à origem e filiação) não só define o estatuto jurídico do indivíduo como determina a sua participação nos órgãos políticos, uma participação que só se torna efectiva mediante o domínio da arte retórica, verdadeiro instrumento do poder no modelo democrático vigente.

${ }^{61}$ À semelhança do que se verifica com Helena, a reabilitação do nome de Teucro, manchado por um acto que também ele náo cometera (é a alucinação do irmão Ájax quem compromete a dignidade do herói - 94), tal como a recuperaçáo do onoma ilustre de Menelau, perdido juntamente com as insígnias reais e oculto sobre os andrajos de náufrago, tornam-se determinantes no renascimento pleno dos heróis e na reposição de uma verdade oculta sobre a aparência. 
vida e verdade/aparência. Fulcro destas antíteses, a personagem de Helena-Penélope ${ }^{62}$, com que Eurípides surpreende ab initio o público ateniense, protagoniza assim uma segunda versão do mito que o trágico inaugura nos palcos atenienses - um «dissos mythos", no dizer de Wolff ${ }^{63}$, que leva às últimas consequências a prática do dissos logos, divulgada pela escola sofística.

Pesaroso lamento pelos seus longos anos de exílio e pelas muitas vidas perdidas nas margens do Escamandro (52-53) em nome de uma vã aparência, o monólogo inicial da protagonista deixa, ao mesmo tempo, escapar ténues rasgos de luz, que prenunciam a reposição da verdade e o feliz desfecho da aventura dos espartanos. No elogio da inexcedível virtude do falecido Proteu, assim como na alusão à filha Teónoe, de nome clarividente, promete-se à partida o desvelar de todos os enganos que condenam a protagonista a um estado de quase morte (286). Mas enquanto a profetisa egípcia personifica a vida, o perigo surge representado na personagem do irmão Teoclímeno, sucessor de Proteu e pretendente de Helena, que ameaça converter em verdade a ilusória uniâo da protagonista com um príncipe bárbaro. Na figura de Proteu, convergem, portanto, os conceitos de vida e morte, luz e trevas, e são os seus descendentes o reflexo deste contraste que o próprio cenário tonaliza. Com efeito, à imagem de renovação contínua sugerida pelas fertilizantes

${ }^{62}$ Cf. supra n. 7

${ }^{63}$ Sem deixar de notar as coincidências que o texto da Helena mantém com os exercícios antilógicos, de linha reconhecidamente sofística, C. Wolff ("On Euripides' Helen”, HSCPh 77, 1973, 77-78) alude a esta tragédia como dissos mythos, expressão decalcada de dissos logos, que salvaguarda, no entanto, a diferença entre o discurso retórico e o poético. $\mathrm{Na}$ realidade, o que faz Eurípides é dar forma dramática à conhecida tese sofística segundo a qual toda a realidade admite duas leituras antagónicas. Sobre as diversas interpretaçóes avançadas para o fragmento dos dissoi logoi, atribuído a Protágoras, vd. E. Schiappa, Protagoras and Logos. A study in Greek Philosophy and Rethoric, Columbia, ${ }^{2} 2003,89-102$. 
correntes do Nilo contrapóe-se, num primeiro relance, a ideia de morte que o túmulo do faraó convoca. Rapidamente, porém, o espectador percebe que a salvação da heroína, já prometida pelo deus mensageiro, reside ali mesmo, no sepulcro do falecido Proteu, que perpetua post mortem a missão protectora desempenhada em vida por incumbência dos deuses. Completam o quadro cénico as imponentes muralhas do palácio, que evocam a grandiosa fortaleza troiana, marcada pelo signo da morte e da destruição. Comparado por Teucro às ricas moradas de Ploutos, deus da riqueza, parónimo não casual do senhor dos infernos, Plouton $^{64}$, o palácio alberga, no entanto, uma promessa de vida e de revelação: nestas moradas procurará Teucro orientação para aquela que será a sua nova vida; ali se dissipará o engano da protagonista quanto à anunciada morte de Menelau e é ainda no seu interior que o Atrida vem a retomar a dignidade de comandante das tropas aqueias, antes obscurecidas pelo traje de náufrago.

Idêntica é a função desempenhada, a nível cénico, pela indumentária e adereços, que projectam visualmente este contraste luz/trevas ao mesmo tempo que acompanham a complexa dinâmica gerada em torno do par verdade/aparência. Trajando vestes claras (assim o depreendemos das posteriores palavras de Teoclímeno nos vv. 1186-7), bem de feição com a inocência que reclama, Helena emerge branqueada do quadro de luto e devastação que as suas palavras revocam na mente do espectador. Uma imagem enganadora e um nome sem corpo são apontados como causa do desaire troiano e da infâmia a que fora votada.

Algumas questôes se colocam, no entanto. O que pensar desta nova Helena cujos gestos e as palavras são o único garante

${ }^{64}$ De acordo com C. Wolff (op. cit., 64, n. 11), este jogo vocabular é claramente sugestivo da ameaça de morte personificada na figura do rico faraó, cujo nome evoca uma das designaçốes atribuídas a Hades, quando associado a Deméter: Klymenos. 
da virtude que lhe define a essência? Poderia esta versão - francamente desconhecida ${ }^{65}$ e, no contexto da tragédia, ainda não explorada - substituir sem resistência aquela que se esperava ver reposta pelo autor ${ }^{66}$ ? Recusar a veracidade do logos da protagonista seria, para uma plateia que bem conhece a gramática do drama trágico, presumir o desvio face a alguns dos seus mais elementares preceitos e a suspensão do primeiro dos compromissos tacitamente estabelecidos entre o tragediógrafo e o seu público, quanto à partilha de uma certa "verdade" dramática ${ }^{67}$. Por outro lado, aceitar a virtude e inocência da Tindárida,

${ }^{65}$ Segundo D. J. Conacher (op. cit., 1967, 286), não haveria muitas versôes do mito em circulação na época de Eurípides.

${ }^{66}$ A surpresa inicial do público, provocada pela completa reconfiguração do ethos de Helena, é não só justificável como previsível se recordarmos que a Espartana é invariavelmente apresentada por Eurípides como anti-modelo da esposa virtuosa (vd. supra n. 6). A. Komornicka (op. cit., 17-18) aventa, contudo, a possibilidade de estas censuras impiedosas dissimularem uma velada ironia por parte de um trágico cujo lema diz ser: «Tout comprendre c'est tout pardonner». A hipótese colocada não nos parece ilógica, mesmo porque, como afirma, as censuras partem inclusive das mais criminosas entre as personagens. Mais problemática, todavia, é a possibilidade de público ateniense ter sido sensível, à semelhança de qualquer crítico moderno, a este tipo de subtileza.

$67 \mathrm{Na}$ tragédia grega, o dolo e o engano eram apenas veiculados no espaço da acção, não se estendendo ao domínio extra-cénico. Para o público vigorava, assim, no tempo de duração da tragédia, o que a Teoria da Literatura contemporânea designou de "suspensão da descrença», um mecanismo de recepção que lhe permitia transigir com eventuais soluçóes fantásticas ou inverosímeis apresentadas pelo trágico, a exemplo do recurso ao deus ex-machina. Munido de um background que o conhecimento do mito lhe conferia e progressivamente inteirado da verdadeira identidade das personagens, bem como do seu carácter, propósitos e pensamentos íntimos (na transmissão destes dados era o monólogo o expediente preferencialmente utilizado), o espectador era investido pelo trágico de um conhecimento supra-dramático que lhe permitia identificar de imediato a mentira e a dissimulação, estas reservadas ao diálogo dos heróis com os seus oponentes (ou outras personagens passíveis de obstar aos seus planos). Ora, ao permitir-se suspeitar da verdade das palavras da protagonista no monólogo inicial, o espectador teria de admitir a quebra destes pressupostos e a violação do que a sua experiência definira como norma. 
reconhecer como mera ilusão a imagem cristalizada de uma Helena culpada e odiosa, obrigá-lo-ia a reformular todo um código de leitura que a estreita familiaridade com a tradição épica e com um certo modelo de tragédia lhe haviam fornecido. Subvertendo a própria estrutura convencional do drama trágico e abolindo as fronteiras que separam o domínio da ficção do espaço extra-cénico, ou a ilusão da realidade, o trágico começa, assim, por converter o espectador em participante directo de um complexo processo de anagnórise que o monólogo inicial da heroína desencadeia. Assimilado a quantos por uma sombra se haviam defrontado em Ílion, ou equiparado a Páris, que, arrebatando de Esparta um fantasma, acreditara estar na posse da beldade prometida, o próprio público vê assim estremecer, face a esta nova Helena, a inconsistente certeza em que a poesia o fizera crer sem restriçóes. Assim transportado para o plano das personagens, desconhecedoras a priori das surpresas que a acção lhes reserva, o espectador não teria tido uma reacção muito distinta da pertinaz incredulidade posteriormente exibida por Teucro e Menelau. Afinal - e a despeito de todas as evidências -, como poderia esta inesperada revelação da heroína arredar sem apelo e inequivocamente a culpa que desde sempre expiara? A suspeita parece bastante cómoda para o espectador - que naturalmente rejeita a ideia de confessar o erro contido na sua preconcebida imagem de Helena, até então transformada em objecto catártico do ódio geral alimentado contra Esparta -, tal como o seria mais tarde para os heróis gregos, por sua vez renitentes em admitir a inutilidade do esforço empenhado na conquista de Tróia. Esta previsível hesitação partilhada pelas personagens e pelo público, resistente à novidade mas inevitavelmente conduzido pelo fluxo dos acontecimentos dramáticos, não seria, de resto, discordante da postura de dúvida a que toda a intriga insistentemente convida. Na realidade, o objectivo central de Eurípides parece ser o de 
levar a assistência a colocar em causa, desde o primeiro momento, as suas mais firmes convicçôes, a questionar a solidez de todo o conhecimento e daí a problematizar a natureza da verdade, não raro oculta sob as sombras impenetráveis da aparência.

Visível não apenas na promoção desta atitude céptica face ao valor absoluto do ser e do conhecer, a marca da Sofística afirma-se também na permanente sugestão do carácter dual da realidade, que a figura da Espartana exemplarmente enforma. Com efeito, a imagem de ambiguidade de que a tradiçẫo a fizera herdeira ${ }^{68}$ tem nesta tragédia uma expressão concreta, materializando-se na oposição estabelecida entre a verdadeira Helena e o seu eidolon ou entre os dois mundos a que presidem ${ }^{69}$ o da realidade e o da ilusão. Esta antinomia vai, no entanto, assumindo, ao longo do argumento, diversas formulaçóes, consoante exprime problemas de ordem epistemológica (palavra/facto; razão/sensação; verdade/opinião), ontológica (nome/corpo; corpo/espírito) ou mesmo ética (culpa/inocência; bem $/ \mathrm{mal}) .^{70}$

Onomalpragma (nome/acção) é possivelmente a mais expressiva destas dicotomias equacionadas no discurso dramático. Sustentando cabalmente a retórica de defesa da protagonista, que reporta todas as acusaçóes ao nome de que Hera a desapossara, a sua relevância insinua-se, antes disso, na apresentação das figuras

${ }^{68}$ Sobre a reconhecida ambiguidade de que a figura de Helena goza na tradição poética, $v d$. A. M. Komornicka (op. cit., 9).

${ }^{69}$ A. Komornicka (op. cit., 19-20) refere que a duplicação de valores, ideias e ambientes na Helena, reflexo da oposição estabelecida entre a protagonista e o seu eidolon, sugere a criação de dois mundos paralelos: o da realidade e o da ilusão, que a estrutura antitética da peça claramente reproduz. C. Segal (op. cit., 303), por sua vez, constrói um esquema diagramático onde traça com clareza a fronteira entre estes dois mundos de Helena.

${ }^{70}$ Todas estas dicotomias são documentadas e criteriosamente ponderadas por A. M. Komornicka (op. cit., passim), que faz uma enumeração detalhada das questôes de matriz sofística levantadas pelo argumento de Helena. 
egípcias. Efectivamente, não nos parecem anódinos os versos iniciais, em que a heroína se detém em consideraçôes sobre os nomes de ambos os filhos de Proteu. Afinal, o que infirmam ou confirmam a respeito da actuação destas personagens contribui visivelmente para lançar o debate em torno do problema da orthotes onomaton ${ }^{71}$, que marcará presença ao longo de toda a intriga. De facto, enquanto o nome 'Teoclímeno' ('o que escuta os deuses'), sugestivo de um carácter piedoso (9-10), se mostra contrastante com a acçấo da personagem que designa, o mesmo não acontece relativamente ao de Teónoe, que se coaduna em pleno com a divina clarividência revelada pela profetisa. Por outro lado, no signo 'Teoclímeno', a raiz do verbo 'ouvir', termo com que kleos ('a palavra que se faz ouvir', donde 'fama') mantém relação etimológica, parece anunciar o lugar que a glória, enquanto bem etéreo e ilusório, ocupará na acção ao lado da beleza, um conceito do domínio da aparência subtilmente sugerido pelo nome de nascença da virgem: Eidô. Permeados de uma ambiguidade que caracterizará sem excepção todas as personagens do drama, os nomes dos príncipes egípcios parecem, pois, encerrar duas antíteses cardinais na discussão do tema verdade/aparência: enquanto Teoclímeno representa a oposição entre fama (onoma, kleos) e acção (pragma, ergon), a mudança do nome da profetisa de Eidô para Theo-noe sugere a prevalência do intelecto (nous) sobre o bem ilusório que a beleza física (Eidôs) configura. Mesmo se enquadradas no formato convencional dos prólogos de Eurípides e aparentemente cumprindo uma simples função informativa, estas consideraçôes onomásticas aduzem, no entanto, importantes indícios quanto ao drama da protagonista. Basta recordar que, empenhada em reabilitar o nome infame, discordante da sua conduta recta e virtuosa, Helena contará

${ }^{71}$ Vd. supra n. 46 . 
com a sua finura de espírito para provar o carácter ilusório da malfadada beleza que o eidolon ${ }^{72}$, etéreo e nebuloso reflecte.

Sem que, no entanto, se reduza a um inconsequente exercício de especulação filosófica a respeito da relação - natural ou arbitrária - entre a linguagem e a realidade por ela representada, a ponderação da dicotomia onomalpragma, que aqui se introduz, convida o público a reflectir sobre o uso da palavra para lá do próprio contexto dramático ${ }^{73}$, ao mesmo tempo que relança a discussão a respeito da idoneidade do discurso poético na transmissão da verdade. Ao afirmar "Não fui eu a causa da guerra de Tróia ou o prémio da lança helénica, mas o meu nome» (42-43), Helena, numa implícita alusão à função mimética do discurso, parece identificar a palavra com o simulacro forjado por Hera, sugerindo o efeito nefasto da aparência vã e inane que veicula:

«Por minha causa, muitas foram as almas que se perderam ao longo das correntes do Escamandro (...) Por minha causa, tantos homens morreram, por causa do meu nome, fonte de tantas penas» $(52-53)$.

${ }^{72}$ Note-se a deliberada relaçáo etimológica existente entre o termo eidolon e o nome de infância da profetisa, Eidô, que, segundo D. Sansone ("Theonoe and Theoclymenus", SO 60, 1985, 20) remete claramente para a ideia de beleza física. A mudança de nome da profetisa antecipa, assim, a nosso ver, a transformação que sofrerá também o da protagonista no decurso da peça. $\mathrm{Na}$ verdade, enquanto nos vv. iniciais, 'Helena', nome emprestado ao eidolon, é sinónimo de beleza pérfida, o final da peça celebra a reabilitaçáo da fama protagonista, colocando em evidência, sobre a bela forma, o seu espírito virtuoso.

${ }^{73}$ Bastante plausível seria uma a imediata transposição do debate para o contexto político-militar, onde, na prática, era habitual questionar a relaçáo palavra/acção. $\mathrm{Na}$ verdade, se a isegoria era, por um lado, um direito inerente à participação democrática, a existência de medidas sancionatórias para um uso doloso do discurso político faz prova de que os cidadãos de Atenas estavam já bem conscientes do poder dúplice da retórica. Para mais, na sequência do desastre siciliano, resultado das promessas vãs de um político deslumbrado, a questão do uso negligente ou doloso do discurso seria um tópico a que o público ateniense seria particularmente sensível. 
Não é, contudo, o nome ou, lato sensu, a palavra o único sustentáculo da ilusão, mas também a beleza (morphe) ou a imagem, com que a visão tolda o entendimento. De resto, ao mesmo tempo que atribui o desastre troiano ao onoma que, volátil e imaterial, "pode estar em muitos locais» (588) e multiplicar-se indefinidamente (conforme observará Menelau nos vv. 497-99), a protagonista culpa também a sua beleza - e fá-lo com notória insistência - de todas as desgraças decorrentes da guerra (262-264, 304-305). Trazendo, assim, a cena as conhecidas teses pré-socráticas acerca da natureza falaciosa dos sentidos e da descontinuidade existente entre linguagem e real ${ }^{74}$, ao mesmo tempo que retoma as consideraçōes sofísticas a respeito destes tópicos, Eurípides alia o debate de teor epistemológico à reflexão meta-literária em torno do próprio $\operatorname{drama}^{75}$, que se faz, à semelhança do eidolon, de palavras e imagens. Verosímil sem ser verdadeiro, o espectáculo teatral, na sua tentativa de representar a realidade, assume-se, assim, como simples produto de ilusão. Mas se a apate parece, em alguns casos, obscurecer a verdade, em muitos outros, como o avanço da acção deixará perceber, afirmar-se-á como o único meio eficaz para aclará-la.

Que o papel da poesia se encontra implicado nesta discussão em torno da antinomia verdade/aparência confirma-o, ainda no prólogo, a cena de Teucro, onde os termos 'opsin', 'eikồ e 'mimema' (vv. 72-74), conotados com a arte dramática, convertem Helena em simples imitação de si mesma, relembrando ao

${ }^{74}$ Já o pré-socrático Demócrito de Abdera, que A. López Eire ( $o p$. cit.,221-23) apresenta como precursor das teorias da linguagem professadas pelos sofistas Górgias e Protágoras, reflectira amplamente sobre a relação entre 'discurso' e 'real', afirmando a impossibilidade de a palavra reflectir a verdade, de que seria uma mera sombra ( $v d$. Democr., fr. B117 D-K.).

${ }^{75}$ Sobre o tema da reflexividade literária na Helena, cf. E. Downing, "Apatê, agôn and literary self-reflexivity in Euripides' Helen" in M. Griffith, D.J. Mastronarde, eds., Cabinet of the Muses: Essays on Classical and Comparative Literature in Honour of Thomas G. Rosenmeyer, Atlanta, 1990. 
público o estatuto ficcional de uma personagem que acaba sendo sempre, em última análise, uma mera sombra da realidade:

"Que espectáculo é este a que os meus olhos assistem?! Vejo a imagem sanguinária da mais odiosa das mulheres, aquela que me perdeu a mim e a todos os Aqueus! Que os deuses te esconjurem, por seres de Helena uma imitação tão perfeita!» (72-75)

No entanto, ao mesmo tempo que toma a realidade pela aparência e o fantasma pela verdadeira Helena, Teucro admite, ainda que involuntariamente, o erro contido na sua percepção e nas injúrias dirigidas a uma mulher inocente, penitenciando-se por um engano que parece ser a causa hibrística ${ }^{76}$ das mortes reais ocorridas em Tróia: «Foi erro meu. Cedi à ira mais do que devia.» (80). Assim, embora não seja uma anagnórise nos moldes tradicionais que o público presencia, até porque o guerreiro mostra não ter consciência do alcance da sua descoberta, năo se pode negar que as suas palavras restituem à Tindárida a face virtuosa que sempre lhe fora negada, desvendando, de algum modo, aquela que a própria assegura ser a sua verdadeira identidade:

«Ainda que o teu aspecto seja idêntico ao de Helena, como é diferente o teu coração!» (160-61)

${ }^{76} \mathrm{O}$ erro de Teucro reveste-se, de facto, de um sentido trágico, remetendo, uma vez mais, para a reflexividade da própria tragédia, no qual o conceito de hamartía assume um lugar de destaque. A ruína de Tróia ficaria, assim, a dever-se a um erro dos heróis gregos e troianos, que, enredados no engano da sensaçáo, haviam cedido à ira mais do que deviam, travando uma guerra tão devastadora quanto vã. $\mathrm{O}$ evidente paralelo com a ira funesta de Aquiles permite, pois, transferir, náo só para Teucro como para os demais guerreiros homéricos que ele representa, a culpa até aí atribuída a Helena. É, afinal, uma imprudente cedência à ilusão a verdadeira causa da guerra e não o adultério da Espartana. 
Esta referência ao binómio corpo/espírito, numa associação directa com os conceitos de aparência e verdade, vem, mais uma vez, salientar o carácter ambivalente da personagem, reflexo da dupla natureza do real e prova da indissolúvel complementaridade dos termos 'ser' e 'parecer' ${ }^{\text {'77. Durante }}$ toda a cena, contudo, Helena persiste em negar a aparência, ocultando sempre o nome infame $(99,109,115,117)$, no que pode ser, mais do que simples medida de prudência, uma sofisticada encenação do verdadeiro eu. Afinal, esta omissão de identidade é apenas o retomar do discurso de abertura, onde a Espartana se distancia radicalmente da imagem criada por Hera à sua semelhança, negando a fama de ignomínia que lhe ficara associada. Para o problema da relação entre o drama e a realidade, que na cena se vai subtilmente esboçando, propóe assim Eurípides a conveniência do paradoxo, ao deixar claro que a farsa mantida pela protagonista revela a Teucro a mesma verdade que lhe escamoteia. Alguns autores usam inclusive a expressão 'pseudo-reconhecimento' ${ }^{78}$ para aludir ao insight do guerreiro grego que, longe de ser uma presença dispensável na orgânica dramática ${ }^{79}$, acabará por expressar o carácter

${ }^{77}$ Esta complementaridade do par aparência/essência está lapidarmente documentada num fragmento de Górgias (fr. B25 D-K), onde é atribuída ao sofista a seguinte afirmação: "O ser eclipsa-se se não lhe outorgarmos a aparência; a aparência extingue-se se não lhe outorgarmos o ser.»

${ }^{78}$ A. M. Komornicka (op. cit., 21), entre outros, interpretam, efectivamente, toda esta dinâmica como um "pseudo-reconhecimento", apresentando-a como promessa defraudada de uma anagnórise que só vem a concretizar-se com o surgimento do companheiro de Menelau.

${ }^{79}$ Teucro não deve ser considerado, quanto a nós, a figura inócua que «n'a rien à faire ici, dans l'histoire de l'Hélène Égyptienne», «l'exemple éclatant de la maladresse d'Euripide», como pretende G. Karsai ("Teucros dans l'Hélène d'Euripide", Pallas 38, 1992, 217). Pelo contrário, o discurso do guerreiro não omite nenhum dos temas de cariz sofístico que serão desenvolvidos ao longo da acção, além de que ajuda a levantar o véu quanto à natureza dúbia da heroína. 
irredutivelmente dúplice da protagonista, numa evocação clara da teoria dos dissoi logoi, fórmula única de verdade:

"Que Helena tenha uma morte vil e não mais regresse às margens do Eurotas. E quanto a ti, senhora, que sejas para sempre afortunada.» (162-163)

Exprimindo a própria ambiguidade da linguagem e sugerindo a dupla possibilidade de interpretaçáo que uma mesma realidade autoriza, a ironia trágica que preside ao discurso do guerreiro, em muitas situaçóes contraditório, coloca, assim, em destaque as principais coordenadas ideológicas da acção. De facto, é na cena de Teucro que Eurípides introduz, de forma viva e cabal, o problema da aporia do conhecimento, responsável pela feição trágica tantas vezes negada a esta peça, onde apenas uma verdade - a da impossibilidade de um conhecimento absoluto e imutável do real - adquire os sólidos contornos de uma certeza. «Vi-a com os meus olhos, tal como te vejo a ti.» (118), afirma Teucro, convicto da fidedignidade da mesma visão que pouco antes acreditara ser fonte de engano (80). Ao demonstrar, assim, o carácter falacioso dos sentidos, que se apresentam simultaneamente como obstáculo e instrumento da verdade, o dramaturgo faz recrudescer na mente do espectador a desconfiança e a dúvida sobre tudo quanto presencia, em particular sobre o carácter da protagonista. Como discernir qual de entre as duas Helenas - a Troiana ou a Egípcia é, enfim, a verdadeira? As afirmaçóes de Teucro reproduzem, em última análise, aquele que é o dilema presente do público, dando, ao mesmo tempo, consistência à posterior reacção de Menelau, que, de modo semelhante, tomará a evidência por ilusão dos sentidos e a verdadeira Helena por um fantasma.

Desvelar toda a verdade oculta sob o véu da aparência torna-se, pois, desde o início da peça, o objectivo perseguido 
por espectadores e personagens. A empresa porém, tropeça a cada passo num conjunto de subtis incongruências que fazem imediatamente prever a sua inviabilidade. Nem mesmo a protagonista parece escapar à armadilha dos sentidos, para a qual adverte permanentemente os interlocutores: se primeiro lamenta o erro a que a visão do eidolon induz o exército helénico e advoga a falsidade da fama que granjeara, mais tarde é erradamente levada a crer no desaparecimento de Menelau, persuadida por simples rumores que lhe chegam na voz do mesmo Teucro, pertinaz credor da ilusão montada em Tróia. Só uma inteligência supra-humana pode esclarecer a verdade que a limitada natureza do Homem não alcança. A solução apontada pelo coro - a consulta da virgem que partilha a omnisciência dos deuses - surge assim como único caminho para a dissolução deste engano na mente de Helena.

Enquanto se ausenta para ouvir as palavras da profetisa, é Menelau, o herói andrajoso e abatido que chega a terras egípcias, quem dará continuidade à reflexão em torno dos binómios onoma/pragma e essência/aparência. As antíteses adquirem desde logo destaque pelo confronto da situação real do Atrida, diminuído ante a sumptuosidade do palácio de Proteu, com a imagem do herói coroado de glória, a que as suas palavras dão forma:

«Estou certo (...) de que fiz embarcar para Tróia o melhor dos exércitos, não como um tirano, que lidera as suas tropas recorrendo à força, mas como um comandante, a quem a juventude helénica seguiu de bom grado.» (393-96).

É, pois, explorando as virtualidades expressivas da componente visual do drama e a ambiguidade permitida pela própria linguagem teatral que Eurípides consegue duplicar as possibilidades de leitura desta cena. 
Numa primeira instância, o acentuado contraste entre indumentária e cenário sugerem a tibieza de um guerreiro cuja glória passada se reduz a um discurso de auto-elogio, frágil ante a evidência da miséria presente. Sob esta perspectiva, os andrajos de Menelau são apenas a materialização do seu carácter, que uma fama vã e infundada durante anos ocultara. Despojado das esplêndidas vestes e luxos de outrora, o Atrida revela-se agora na sua essência, deixando cair a máscara do comandante exemplar - uma ilusão que a lembrança dos feitos passados procura manter viva. A situação de Menelau afigura-se, sob esta perspectiva, inversa à de Helena: enquanto a Tindárida está cada vez mais próxima de recuperar o bom nome, o herói vê progressivamente apagar-se o brilho da glória alcançada em Tróia, um espaço dominado pelo engano e pela ilusão. No entanto, se considerarmos a problemática filosófica subjacente à intriga, verificaremos que as consequências a extrair dos monólogos de Helena e Menelau são rigorosamente coincidentes: por um lado, o ser distingue-se do nome; por outro, a exterioridade confunde-se não raras vezes com a interioridade, explicando a impossibilidade de uma perfeita distinção entre o verdadeiro e o aparente.

Mas a oposição que se verifica entre o opulento palácio egípcio, imagem das grandiosas muralhas de Ílion, e os modestos farrapos de náufrago envergados pelo rei de Esparta oferece ainda uma outra possibilidade de leitura, concordante com o ponto de vista do próprio Menelau. Na óptica do herói, a aparência de náufrago encobriria apenas a virtude que o tornara célebre como conquistador de Tróia. Assim, ao contrário de Helena, que procura demonstrar o dissídio existente entre o nome e o ser, Menelau reivindica uma identificação entre a fama (onoma) alcançada no passado e o seu verdadeiro valor (pragma). Em ambos os casos, porém, a aparência vem a revelar-se um óbice 
ao reconhecimento, como confirma o diálogo entre Menelau e a porteira do palácio de Teoclímeno.

Esta cena, à semelhança da de Teucro, com a qual, de resto, mantém inúmeros pontos de contacto, tem sido, a nosso ver, mal compreendida pela generalidade dos críticos, que se fixam na sua suposta feição cómica ${ }^{80}$, omitindo as questóes essenciais que levanta em redor da antinomias verdade/aparência. Assim, por detrás dos traços de comicidade que apresenta, a inversão de papéis entre a serva do palácio e o rei de Esparta sublinha a imagem trágica do soberano decaído, vítima da aparência mais do que dos deuses (403) ou do próprio destino ${ }^{81}$. O rei recorda, pois, com amargurada nostalgia, o "célebre exército» (453) e «os felizes sucessos de outrora» (457), que a sua realidade presente transforma numa vã e inconsistente lembrança. O nome respeitável e a glória alcançada em Tróia, valores relativos num mundo onde a própria verdade parece flutuante, revelam agora a sua natureza efémera e ilusória: «Na tua terra, não duvido que fosses um homem ilustre, mas não o és aqui» (454).

O onoma parece, pois, estar na origem do pathos de Menelau, à imagem do que sucede com Helena: se, para esta, o pior dos males advém da sua reputação infame e imerecida (287-88), para o herói, o limite das desgraças reside na perda da fama granjeada entre os Gregos (417-18). Perdido num mundo de leis e costumes bárbaros, onde se vê forçado a «mendigar o pão a outros soberanos» (511-12), Menelau vale-se de uma última esperança. Confiado de que o seu nome célebre será reconhecido pelo rei local, de quem certamente receberá o esperado auxílio, o Atrida ignora, contudo,

${ }^{80}$ Vd. infra p. 97.

${ }^{81}$ Com efeito, enquanto os heróis de Ésquilo são sobretudo vítimas do destino inexorável, as personagens da Helena euripidiana parecem condenadas à humana limitação que ora os impede de aceder à verdade absoluta ora os torna presas fáceis da aparência. 
que o onoma, promessa das almejadas benesses (502), esconde uma real ameaça de morte. Ironicamente, porém, se primeiro acredita ser o nome a garantia do seu imediato reconhecimento, em breve se recusará a aceitar a presença da sua consorte no palácio do soberano, apesar de uma espantosa coincidência de nomes:

«Pois se eu trouxe até aqui a esposa que resgatei em Tróia e a deixei em segurança numa caverna, uma outra mulher, com o mesmo nome da minha, habita neste palácio. (...) É que, ao que parece, muitos homens por esse mundo fora têm o mesmo nome, tal como uma cidade pode tê-lo igual ao de outra cidade e uma mulher ao de outra mulher.» (485-88; 495-99)

Mesmo na pista da verdade - a certeza de que nome e objecto são termos distintos, não obrigatoriamente coincidentes, Menelau cede de novo à ilusão. De facto, embora o diálogo com a porteira encerre uma revelação que parece precipitar a anagnórise do par amoroso, o herói, de início visivelmente surpreso e intrigado (471-75), acaba por encontrar na simples homonímia a explicação para a presença no palácio de uma mulher chamada Helena, filha de Zeus ou de Tíndaro e proveniente da Lacedemónia. À semelhança do que acontece com Teucro, que, colocado diante da verdadeira Helena, julga tratar-se de mera semelhança o que lhe mostra a visão, também o Atrida, apesar de confrontado com esta coincidência de nomes, prefere acreditar que a esposa é aquela que deixou na caverna, à guarda dos companheiros.

Enquanto Menelau permanece na ignorância da verdade, a Tindárida regressa na companhia do coro, visivelmente revigorada pela auspiciosa revelação de Teónoe. A longa errância do rei de Esparta e o naufrágio que o desviara para um local não muito distante dali são profecias que anseiam por uma confirmação breve. A acção parece, desta sorte, encaminhar-se 
a passos largos para o reconhecimento dos heróis. Porém, novamente a aparência vem interpor-se no caminho de ambos, retardando uma anagnórise claramente em iminência, a avaliar pelas palavras que precedem o reencontro dos heróis: «Ai de mim, quando chegarás? Como anseio pela tua vinda!» (540). De facto, embora conhecedora da presente circunstância do esposo, a heroína deixa-se tomar pelo terror que lhe desperta a visão do homem de aspecto esquálido e aparência selvagem com que se depara (45), longe de encontrar nele a tão ansiada resposta para a questão antes formulada. Todavia, ao espectador mais atento não passaria despercebida a exagerada reacção de Helena, bem diversa daquela que observa aquando do seu encontro com Teucro, em idênticas circunstâncias ${ }^{82}$, e contrária à sua consciência do carácter enganador das aparências. A dúvida impōe-se: quererá Eurípides sugerir que a heroína reconhece neste andrajoso náufrago o errante Menelau de que lhe falara a profetisa? Neste caso, porque simularia o medo, lançando-se numa desenfreada corrida em direcção ao túmulo de Proteu? Certamente nenhum outro argumento seria tấo convincente na defesa da sua imagem de esposa casta e fiel como a estratégica encenaçáo de um rapto, em que mostrasse resistir a todo o custo à perseguição. Contudo, a questão que aqui colocamos náo chega a ter - ou sequer o pretende - uma resposta conclusiva, a exemplo de muitas outras neste intrincado universo de ilusôes criado por Eurípides. De qualquer modo, o regresso ao tema do rapto, já desenvolvido no párodo (186-90), contribui para reforçar o paralelo entre Teoclímeno e Páris, abonando em favor da inocência de Helena.

Apesar desta sua primeira reacção de repulsa, que leva Menelau a tentar uma primeira aproximação, Helena superará,

${ }^{82}$ Entre outros autores, G. Karsai (op. cit., 219) observa o carácter injustificado desta reacção da protagonista, a quem a imagem miserável do náufrago mais facilmente inspiraria a compaixão do que o temor. 
muito antes do Atrida, o obstáculo das aparências, reconhecendo, por detrás das suas miseráveis vestes (554), o herói que vem resgatá-la do cativeiro. Na verdade, tal como Teucro, Menelau identifica em Helena apenas uma admirável semelhança com o eidolon que trouxera de Tróia. Frustra-se assim a expectativa de um reconhecimento mútuo a partir de sinais, que as palavras da heroína, numa clara alusão às convenções trágicas, tinham feito prever (290-91). Eurípides parece, pois, casar um discurso "meta-dramático" com a problemática central da tragédia, plasmando no complexo processo de anagnórise a permanente tensão gerada entre realidade e aparência. De facto, os avanços e recuos que definem a dinâmica teatral do reconhecimento ilustram expressivamente o drama das aparências vivido pelas personagens. Para Menelau, tal como antes para Teucro, as parecenças físicas não são suficientes para que admita estar na presença de Helena. E náo apenas da visão duvida o herói, mas também das palavras da Tindárida, que se apressa a revelar a sua identidade: «Oh! Regressa, enfim, aos braços da tua esposa!» (566). Colocando em causa a veracidade da informação transmitida pelos sentidos, nos quais outrora confiara sem reservas, o herói crê agora estar diante de um phasma forjado por Hécate, simulacro da verdadeira esposa, numa clara reversáo do logos de Helena. Mas a heroína não desiste, empenhada em desfazer este equívoco. Paradoxalmente, porém, aquela Helena que advertira Teucro do engano a que induz a visão, invoca-a insistentemente como garantia da verdade:

"Quando me olhas, não tens a sensação de estares a ver a tua esposa? (...) Ora observa bem! De que prova mais fidedigna precisas? (...) E quem poderá esclarecer-te senão os teus próprios olhos? $(576,578,580)$. 
O mesmo argumento é, todavia, aduzido por Menelau para sustentar uma posição contrária à da Espartana: «Precisamente aí é que reside o problema: já tenho outra esposa.» (581). O diálogo dos heróis actualiza, assim, o problema da aporia do conhecimento, já equacionado na cena de Teucro. No entanto, ao questionar a fidedignidade da visão, que julga estar enferma, tanto como a da própria razão (575), o herói não se limita a dar voz ao cepticismo dominante no meio sofístico, mas vai além do problema epistemológico da percepção e do conhecimento. Com efeito, nesta obstinada recusa em aceitar a verdade que se revela ante os seus olhos, não deve ver-se simplesmente a confirmação da natureza falível dos sentidos, mas sobretudo a defesa do onoma que a empresa troiana coroara de glória. Para Menelau, admitir que se encontra diante da verdadeira Helena significa reduzir o seu passado a uma ilusão e assumir a vanidade da guerra que o tornara célebre. Assim, enquanto a Tindárida persegue a verdade com o objectivo de reabilitar o nome infame, Menelau evita-a a todo o custo, receoso de perder a fama alcançada. Sem mais argumentos para contrapor à incómoda realidade com que é confrontado, o Atrida despede-se apressadamente da mulher que diz "tão semelhante a Helena» (591), repetindo os votos de felicidade já formulados por Teucro. Não é, pois, a ameaça constituída pelo rei local que o afasta, como ao compatriota, das portas do palácio junto das quais procurara auxílio, mas o receio de perder a glória alcançada em Tróia que o leva a esquecer o seu propósito inicial. De facto, a verdade reconhecida pela heroína parece não ter força para suplantar uma ilusão da qual Menelau não pretende apartar-se.

O impasse criado pela própria natureza incognoscível da verdade apenas se resolve com a chegada do anónimo servo de Menelau que inadvertidamente vem revelar a real identidade de Helena. A esta personagem, representante de todas as vítimas 
anónimas de Tróia, caberá, assim, reproduzir as palavras dirigidas pelo eidolon aos companheiros de Menelau, antes de evolar-se nos ares. No seu relato, todos os sofrimentos vividos em Ílion se mostram inúteis, porque causados por uma volátil ilusão que todos acreditavam tratar-se de Helena. A reflexão filosófica é, deste modo, articulada com uma perspectiva humanista da guerra, que se contrapóe à visão heróica consagrada na epopeia de Homero. Afinal, esta fusão do espectro de Helena com o éter, matéria de que fora gerado, é claramente sugestiva da inanidade dos motivos que haviam estado na origem do confronto. Por outro lado, ao deixar a gruta para elevar-se no céu, o fantasma descreve o movimento das trevas para a luz ou do engano para o conhecimento, que tem lugar na história dos heróis. Com a extinção do eidolon, que consubstancia as falsas crenças (611) e rumores (614) em torno do seu nome, a verdadeira Helena recupera, então, a existência de que fora em tempos privada pelas maquinaçóes da deusa (610).

Porém, a forte presença da ilusão e da aparência no discurso e actuação da protagonista, continuará a adiar progressivamente uma afirmação definitiva e absoluta da verdade. Se até ao momento Helena se apresenta como presa da ilusão, ela que, fruto da união dolosa de Zeus e Leda (17-21, 257-259) e vítima de um capricho de Hera, parece condenada pelos deuses a um destino de enganos, é importante não esquecer que a protagonista será a responsável por um ardiloso plano de fuga cuja eficácia se salda no triunfo da aparência sobre a verdade. Efectivamente, ainda que a anagnórise do casal régio defina uma fronteira clara entre um passado de enganos e a realidade restaurada, os heróis continuam a mover-se num mundo de dissimulação e ilusóes de que em breve se tornarão os próprios artífices.

A aparência não estará ausente nem mesmo na cena de Teónoe, que preside a uma nova contenda gerada entre deusas: 
favorável à reposição da verdade que antes obnubilara, Hera opõe-se agora a uma Cípris partidária da ilusão ou, como dirá Helena mais tarde, «tecedora de enganos» (1103-1104). À profetisa, que a chama dos archotes e a luz da verdade iluminam, é assim remetida a decisão derradeira. A cena sugere claramente uma reposição do julgamento do Ida, onde diverge apenas o juiz. A responsabilidade coubera primeiro a Páris, que, cedendo ao engano da beleza e proclamando a vitória de Afrodite, recebera como prémio "uma falsa união» (883), ou - sublinha a Egípcia - «as núpcias ilusórias de Helena» (886). Todavia, da omnisciente profetisa, voz da verdade e conhecedora da justiça, o público esperaria - mesmo a despeito dos receios pouco antes expressos por Helena - o veredicto oposto, uma convicção que se reforça nas primeiras palavras dirigidas à protagonista. Afinal, que outro motivo a levaria a aludir ao simulacro da Espartana senão o propósito de solver as ainda remanescentes dúvidas de Menelau e apadrinhar uma união que é, contrariamente à de Páris e Helena, verdadeira? Nenhuma razão a levaria tão pouco a desprezar, como fizera o príncipe troiano, o dever da hospitalidade tấo caro aos deuses, em favor da voluptuosa paixão de Teoclímeno. Todas estas expectativas se dissipam, porém, face à solução encontrada por Eurípides para colocar a estes heróis romanescos um novo obstáculo: temendo pela ameaça (892-93) que uma decisão desfavorável ao faraó representaria para a sua $v^{\text {vida }}{ }^{83}$ a profetisa decide comunicar a Teoclímeno a presença de Menelau em terras egípcias. A vida dos heróis, retomada com a revelação da verdadeira identidade de ambos, depende desta vez da sua omissão, ao passo que o dolo, causa do terrível morticínio

${ }^{83}$ A confirmar a presciência de Teónoe, esta ameaça voltará a pairar sobre a vida da profetisa logo após a descoberta do dolo por parte de Teoclímeno (1632-35), que é, no entanto, impedido pelos Dioscuros de consumar a vingança contra a irmá. (1642-49) 
de Tróia e da não-vida da protagonista, se apresenta agora como único meio de salvação. Invertida a directa coincidência dos termos vida/morte com os pólos da dicotomia verdade/aparência, o problema dos heróis passa a configurar uma questáo de ordem ética ou axiológica. Sugerindo tacitamente a impossibilidade de se estabelecer uma relação de identidade necessária e inquebrantável entre justo e verdadeiro, ao contrário do que preconizaria Platão no debate travado contra os mestres da Sofística, o discurso de Teónoe deixa à consideração do público a questấo da posiçấo relativa da vida e da verdade na escala de valores. O que seria moralmente correcto: preservar a verdade em detrimento da vida dos heróis e da própria justiça, ou ocultá-la? $\mathrm{Na}$ súplica de Helena, a resposta apresenta-se com clareza:

«Não contes a teu irmão que o meu bem-amado esposo tornou aos meus braços, mas salva-o (...) Se tu, que és profetisa e crês no divino, comprometeres a justiça paterna em nome da fidelidade a um irmão iníquo, vergonha é que dos deuses conheças todos os desígnios, presentes e futuros, mas não o que é justo.» (898-99, 919-23)

Mas o desempenho teatral desta súplica já planeada (831), em que a Tindárida actualiza um código de gestos e atitudes bem conhecido e calculado, demonstra na prática um importante pressuposto do seu discurso, onde a ilusáo se apresenta como instrumento essencial ao desvendamento da verdade: é, de facto, necessário que Teónoe aceda em compactuar com a fraude dos heróis para que o embuste de Hera possa ser esclarecido em Esparta. Que Helena conhece a força persuasiva da ilusão prova-o o estratégico argumento aduzido para rematar a sua rhesis. Se a justiça não fosse em si mesma razão suficientemente válida para demover a princesa egípcia, sê-lo-ia sem dúvida a 
perpetuação da glória paterna (940-44). O tópico, sugerido a Menelau por esta astuciosa Helena, frágil apenas na aparência, será efectivamente retomado na súplica do rei de Esparta, que faz dele argumento central ${ }^{84}$ da sua defesa: "Mas esta tua filha não achará digno que um pai de nome outrora tão ilustre seja invocado do reino dos mortos por vozes de censura.» (966-68). Num momento em que o objectivo dos heróis gregos é o de rumar à pátria para aí repor uma verdade por longos anos obscurecida, o onoma transforma-se, contudo, na preocupação mais premente das personagens: se a fama injusta continua a dominar o discurso da Espartana, Menelau não parece menos obstinado em preservar uma imagem de glória e virtude que reclama nos versos iniciais e finais da sua intervenção ${ }^{85}$. Nem mesmo a profetisa, que se apresenta como sede da verdade plena, consegue eximir-se ao poderoso ascendente da aparência, colocando a descoberto uma face que o nome de infância, Eidô ('imagem'), apenas indiciara. Entre as razões apresentadas para a sua decisão, a justiça é antecedida da honra pessoal (999), que receia ver manchada de infâmia (1001), e da glória do falecido Proteu, argumento que sugestivamente encerra o seu discurso ${ }^{86}$. Assim, a despeito das sucessivas mudanças que parecem conduzir a trama no sentido da verdade - a passagem do anonimato ao mútuo

${ }^{84}$ Ao contrário de Helena, Menelau baseia quase exclusivamente a sua defesa no tópico da reputação e da glória, ainda que este argumento apenas surja formulado de forma directa e explícita nos versos 966-68.

${ }^{85}$ A estrutura em anel, muito usada nos discursos sofísticos, parece ter por função assinalar a importância do tópico, ideia ou argumento que se destaca em posição inicial e final.

${ }^{86}$ Esta motivação não é considerada por M. O. Pulquério ("A Actuação dos deuses na Helena de Eurípides", Humanitas 27-28, 1975-1976, 214), segundo o qual Teónoe justifica a sua decisão com base no respeito por um princípio de justiça interior, conforme à sua natureza (1002), a que se acrescenta a exigência de uma justiça exterior, a ser exercida pelos deuses, neste mundo como no Além. 
reconhecimento dos heróis, a alteração dos desígnios de Hera, e finalmente esta inflexão de Teónoe quanto ao destino do casal régio -, a aparência não chega a perder força numa acçáo que se alimenta da insanável tensão entre contrários.

Sustentáculo da verdade e da ilusão, capaz de ditar a vida ou a morte, o discurso começa por revelar o seu duplo poder neste exercício de persuasáo a que os protagonistas se vêem obrigados para conquistar o favor da virgem. Ora, tal como a retórica, veículo da doxa, pode trazer à luz a aletheia, e tal como a omissão da verdade pode contribuir para a sua plena revelação, também a encenaçáo que Helena propóe a Menelau se apresenta como único caminho para o esclarecimento da verdadeira identidade dos heróis. $\mathrm{O}$ tão desejado regresso a Esparta e a não menos almejada reposição da verdade, requerem, com efeito, a criação de um novo eidolon - desta vez, a sombra do Atrida - e o logro de Teoclímeno, o homólogo de Páris em terras egípcias. Nesta teia urdida por Helena, que a si mesma se vai construindo à semelhança de Penélope, convenientemente compondo e desmanchando os fios da sua história, a palavra é de novo matéria da ilusão e o único expediente passível de neutralizar o pretendente. Morrer «em palavras» (1050-52) é, pois, a sugestão apresentada para a salvaçáo do consorte, a quem cabe agora ilustrar a dicotomia onoma/soma e morte/vida. Para convencer o faraó da sua própria morte, o herói deverá, portanto, enterrar o nome glorioso e assumir uma nova identidade, enquanto a própria Helena compóe de si mesma uma outra imagem - a da viúva fragilizada, disposta a ceder aos apelos de um novo amor. Contudo, se Helena precisa de trocar as vestes brancas pelo trajo negro de luto e colocar a máscara do sofrimento para garantir a verosimilhança da farsa, Menelau encontra na miséria da sua realidade presente os meios necessários para tornar credível o papel que a protagonista o incumbe de interpretar: 
Helena: De ti mesmo. Contarás que foste o único a escapar com vida quando navegavas com o filho de Atreu, e que o viste morrer.

Menelau: E até estes farrapos que me cobrem o corpo te podem servir de prova do naufrágio!..... (1077-80)

A sugerir a intrincada natureza das relaçóes que se estabelecem entre ficção e realidade, a performance das personagens converte-as em actores de um espectáculo que tem lugar no interior do próprio teatro. Nesta discreta metalepse, em que a protagonista chega a assumir a função do autor trágico ${ }^{87}$, produzindo um novo retrato de si mesma, a própria credibilidade do drama fica, segundo Meltzer, comprometida ${ }^{88}$. Com efeito, ao focar nas suas técnicas e expedientes a atenção do espectador, a tragédia apresenta-se-lhe sem pudor como simples imitação ou constructo poético. A quebra da ilusão dramática revela-se, pois, simultânea (senão consequente) da apate forjada pela protagonista, a sugerir a relação de contiguidade entre a verdade e a imitação por meio da qual ela se revela. A arte dramática desnuda-se, assim, ante o olhar do público ateniense, num exercício de reflexividade absolutamente inovador na tragédia clássica. Pela primeira vez, o drama discute-se em si mesmo e a si mesmo, seguindo as linhas do debate sofístico-platónico: será ele um perverso simulacro da verdade ou antes um meio eficaz para revelá-la? Não é a ilusão componente inalienável da

${ }^{87}$ De acordo com I. Holmberg (op. cit., 26-28), já na Ilíada Helena parece assumir uma função análoga à do poeta. Com efeito, enquanto borda num manto púrpura os combates em seu nome travados entre Gregos e Troianos (Il. 3. 125-129), ou mesmo quando descreve os guerreiros Aqueus, na conhecida cena da Teichoscopia (Il. 3. 182-242), vemo-la recriar, sob o ângulo da sua subjectividade, os quadros de guerra em que se movem os heróis, ciente que está da imortalidade com que o canto dos vates coroa o Homem (Il. 6. 354-58).

${ }^{88} \mathrm{Vd}$. G. S. Meltzer, op. cit., 237. 
própria realidade como o é da tragédia? As questôes parecem ficar deliberadamente sem uma resposta conclusiva, assim como as dúvidas sobre a verdadeira essência das personagens, que o quadro da fuga vem reforçar.

Muitos autores, entre os quais Segal e Juffras ${ }^{89}$, têm discutido o significado do massacre dos marinheiros frígios, comandado por Menelau e encorajado pela própria Helena. Numa peça onde a guerra se apresenta como produto de uma funesta ilusão e a glória marcial como um bem efémero, esta cena afigura-se, à primeira vista, desajustada e incongruente, tanto mais quanto se considera dispensável e gratuito o derramamento de sangue bárbaro, a que o plástico relato do mensageiro imprime o colorido vigor da realidade. De interpretação igualmente problemática é a fria determinação de Helena, contrastante com a fragilidade da esposa inerme que, numa primeira parte, aguarda passivamente a chegada redentora de Menelau. Rendido à imagem pesarosa da heroína inocente, que insistentemente se penitencia pelas vítimas de uma guerra vã, o público não deixaria de reagir a esta mudança abrupta, que faz de novo emergir o espectro da Helena desumana e sanguinária, já antes remetida aos céus da ilusão. Com efeito, ao mesmo tempo que recorda a ambiguidade que rodeia a figura de Helena, Eurípides dá mostras do seu traço

${ }^{89}$ C. Segal (op. cit., 309) vê nesta cena uma aproximaçấo da Helena cruel da tradiçáo poética, que conduz os compatriotas ao derramamento de sangue bárbaro, com a rainha inocente, que se coloca desta vez do lado do marido, resistindo corajosamente ao assédio do pretendente. Interpretaçáo em alguns pontos coincidente é a de D. Juffras. (op. cit., 55-57). A autora alude ao desdobramento final da protagonista, que coloca lado a lado a «esposa inocente», principal vítima da guerra, e a «velha Helena», a quem é mesmo atribuído um papel activo no conflito. A duplicidade da heroína em fuga é também referenciada por H. Foley (“Anodos Dramas: Euripides' Alcestis and Helen" in R. Hexter, D. Selden (eds.), Inovations of Antiquity, New York and London, 1992, 144), que vê reproduzida nesta nova Helena "the seductiveness and destructiveness of her rejected alter ego.» 
realista na composição das personagens. Nesta dupla faceta de Helena ou nas duas Helenas finais, como prefere D. Juffras ${ }^{90}$, o trágico reproduz, assim, a complexa mente feminina, onde convivem pulsóes e tendências contrárias, fruto de uma subjectividade densa, não redutível ao paradigma da mulher pérfida ou da esposa virtuosa. Contudo, a maior dificuldade continua a colocar-se sobretudo relativamente a uma frase da protagonista, que em si mesma tem merecido a atenção de grande número de estudiosos: «Onde está a glória de Tróia?» (1603). Ao evocar o cenário da guerra, reconduzindo as personagens ao seu perfil épico e aproximando-as da imagem convencional que assumem na tragédia, Eurípides parece sugerir, numa primeira instância, o poder atractivo que a ilusão - e a poesia como seu veículo privilegiado - exerce sobre o espírito humano. A modernidade que toda a peça respira permite-nos mesmo ver representada nesta cena de fuga o desejo de evasão que o homem satisfaz mediante a criaçáo de universos fictícios. É enfim neste momento dramático que Helena se revela como autora da sua própria história: depois de esculpir a imagem da inocência com o teatro da súplica, de transformar Menelau no herói épico por meio de uma hábil manipulação da palavra, e até de recriar no cenário egípcio os principais quadros da guerra de Tróia (o assédio de um príncipe bárbaro, a entrada camuflada de um grego nas muralhas inimigas e por fim a capciosa mechane em que os bárbaros inadvertidamente colaboram), a protagonista apresenta-se do lado de Menelau, não arrastada pela força, contrariamente à versão relatada por Teucro, mas colhendo orgulhosamente os louros de uma glória que quer ver consumada no plano da realidade. Assumindo de novo o papel do poeta e modelando o seu próprio ethos, a recordar um desejo antes expresso (262-64),

${ }^{90}$ Vd. supra n. 89. 
Helena refaz a sua reputação (kleos), ao mesmo tempo que confere novo sentido a um conflito desencadeado por obra de um rumor (kleos) inane. O duplo sentido de kleos, explorado por Meltzer ${ }^{11}$, com o jogo semântico que potencia, torna-se importante para a descodificação do sentido das palavras dirigidas pela rainha de Esparta aos guerreiros gregos (1603-1604). Para que a empresa troiana e os seus vencedores possam coroar-se de glória, é necessário lutar agora não por um fantasma etéreo, a materialização do rumor infundado, mas pela Helena real que na peça se lhe opóe como encarnação da verdade e da virtude. Neste ponto se distingue, de resto, o veio trágico táo buscado na obra. Afinal, perante o multiplicar sucessivo de ilusōes, quer forjadas pelos deuses quer encenadas pelas personagens, reveladas pelos heróis ou subtilmente insinuadas nas contradiçóes da sua actuação, a verdade quanto à essência de Helena - e da realidade que ela representa - parece escapar ao entendimento do público, numa desconcertante confirmação da aporia do conhecimento, que deixa o homem inevitavelmente à mercê do dolo e do engano. De resto, o próprio esquema romanesco da obra, onde a expectativa se cria e logo se dilui e onde a certeza faz permanentes concessóes à surpresa, serve na perfeição toda uma dinâmica de crença-descrença que atesta a inevitável coexistência do verdadeiro e do aparente. Esta é, enfim, a única verdade com que a ilusão poética logra compensar o esforço inglório do espectador, frustrado na sua tentativa de destrinçar com clareza ambos os pólos da antítese. Em suma, no conceito ambivalente de kleos vemos entrelaçar-se as duas faces de Helena - a da Espartana sanguinária, que a força da tradição mantém presente mesmo após o desaparecimento do eidolon, e a da rainha fiel e virtuosa, cujo nome será no final louvado

${ }^{91}$ G. S. Meltzer, op. cit., 235-36. 
por Teoclímeno (1684) e imortalizado por determinação dos divinos Dioscuros:

Castor: E quando dobrares a meta, finda a carreira da vida, serás celebrada como deusa (...). Já a terra onde primeiro se deteve o filho de Maia, quando contigo viajava através dos céus (...), será doravante conhecida entre os mortais pelo nome de «Helena». (...). (1666-74)

Reforçando, na ausência da protagonista, o carácter dual da existência, a intervenção final dos gémeos parece ainda retomar a teoria sofística dos dissoi logoi. Com efeito, o surgimento ex-machina dos irmãos divinizados nâo invalida a primeira das duas versôes antes apresentadas por Teucro quanto ao seu destino («Morreram e não morreram»:138), premissas que a própria tradição mítica faz complementares ${ }^{92} \mathrm{Na}$ verdade, embora a soluçấo final encontrada por Eurípides, que os imortaliza como astros-guia $(140,1665)$, permita realçar o sentido metafórico do desfecho da peça, com a sugestáo de que a viagem do conhecimento deve considerar a dupla face do real, não se trata de simples casualidade o facto de Castor, a quem o mito atribui uma natureza mortal, ser o único dos dois irmãos a tomar a palavra. Duas verdades contraditórias, tanto a respeito dos gémeos (morreram e não morreram) como da própria protagonista (uma Helena pérfida e casta), parecem ficar enfim asseguradas. De facto, ao apadrinharem a versão regeneradora de Helena, na qual thes cabe um destino igualmente elevado, os Dioscuros não

${ }^{22}$ Segundo o mito (vd. P. Grimal, Dicionário da Mitologia Greco-Latina, Lisboa, ${ }^{3} 1999,122$ ), para que Castor, morto numa contenda, pudesse partilhar com o irmáo a imortalidade, como fora desejo manifesto de Pólux, Zeus permitiu que ambos alternassem entre a vida e a morte, repartindo igualmente o tempo da sua existência. 
vêm certificar uma verdade unívoca e definitiva, depurada enfim de sombras e aparências, mas simplesmente contrapor à tradição o seu reverso.

Deste modo, no jogo de espelhos criado em torno da figura dos gémeos, idênticos na aparência mas na realidade tão distantes como a vida e a morte que os separa ${ }^{93}$, o público é convidado a reflectir sobre a relação do ser com o seu reflexo, verdade e aparência. Num mundo onde a imagem (ou nome) ameaça ganhar vida e substituir-se à realidade de que é simples e vazia projecção, todo o conhecimento se anula e toda a certeza se desfaz numa afirmação triunfante da Sofística.

\subsection{GREgos vS. Bárbaros: o REDEFINIR DE FRONTEIRAS}

Perfeitamente enquadrada na moldura sofística que conforma o argumento da Helena, a dicotomia Grego-Bárbaro não recebe de Eurípides o mesmo tratamento que lhe haviam dado Ésquilo ou Sófocles, a quem se ficara a dever um reforço das fronteiras etnológicas, políticas e sociais de há muito rasgadas entre a Hélade e o mundo náo grego. Pondo de parte o discurso de afirmação nacionalista forjado no contexto da Simaquia de Delos, o trágico inverterá o rumo seguido pelos seus predecessores, em cujas obras se vislumbram reverberaçôes da entấo ainda recente ameaça persa sobre a soberania helénica ${ }^{94}$. Polémico e subversivo, Eurípides não desiste do seu propósito de abalar os mais arreigados dogmas e convicçôes do público ateniense, ao questionar, sob o discreto véu da ironia, os fundamentos da

${ }^{93}$ Ao ceder às instâncias de Pólux, Zeus ditou, logicamente, o afastamento dos Dioscuros, já que a estada do primeiro nos Infernos passaria a corresponder à presença do segundo entre os Olímpicos.

${ }^{94}$ A respeito da relação entre as Guerras Pérsicas e a representação do bárbaro na tragédia, vd. E. Hall, Inventing the barbarian - Greek self-definition through tragedy, Oxford, 1989, 2, 6. 
crença numa superioridade da raça helénica. E se o suporte argumentativo lhe chega das teses dos sofistas Hípias e Antifonte ${ }^{95}$, o ensejo para a desconstrução da antítese Grego-Bárbaro, a que se assiste na Helena, decorre da orientação temática da própria intriga. Trata-se, afinal, de desmistificar mais um dos muitos fantasmas que obstariam a uma correcta percepção da realidade, provando a inconsistência de toda a postura etnocêntrica.

No quadro ameno e acolhedor que se oferece ao espectador nos versos iniciais, pressente-se já este esbater do contraste que separa o mundo grego da barbárie. Da apresentação do cenário, dominado pelas frescas águas do Nilo que fecundam os campos egípcios, não se desprende, de facto, o mais leve vestígio da aridez inóspita bastas vezes associada aos territórios bárbaros, nem mesmo um qualquer indício do perigo que não raro representam para os heróis da Hélade. E mesmo o túmulo de Proteu, em destaque na skene, longe de prenunciar a desgraça da protagonista, servir-lhe-á de salvaguarda e protecção contra a ameaça permanente do novo rei.

Ainda assim, os principais elementos que compóem o estereótipo do Bárbaro não estão ausentes do prólogo da peça. De facto, ao público de Eurípides não passaria certamente despercebida a alusão ao regime monárquico vigorante no país do Nilo ou mesmo à crueldade que anima Teoclímeno na ultrajante perseguição movida à hóspede espartana. Tão pouco lhe seriam indiferentes o desrespeito do soberano pela hospitalidade devida aos estrangeiros ou a sumptuosidade do palácio faraónico que deslumbra Teucro. No entanto, estes traços de tirania, incivilidade e opulência com que a tradição literária pintara o mundo bárbaro parecem ser imediatamente contrabalançados com sinais evidentes da ordem civilizacional helénica, que vêm atenuar

${ }^{95}$ Vd. supra capítulo 2.1.. 
as dissonâncias culturais entre Gregos e não-Gregos: em Proteu, único «senhor de todo o Egipto» (5), reconhecem os próprios deuses o mais virtuoso de entre os mortais (47) quando o elegem guardião da castidade da esposa de Menelau; à impiedade do seu sucessor, por sua vez, opóe-se a clarividência quase divina da irmã Teónoe, de quem Helena apregoa os dons proféticos e em quem Teucro busca orientação para a sua viagem fundacional. E que dizer, enfim, da grandiosidade das moradas de Proteu, que a comedida sobriedade helénica veria como excesso? Imagem de uma civilização próspera e evoluída ${ }^{96}$, as imponentes muralhas inspiram segurança e protecção aos estrangeiros que delas se acercam, ao mesmo tempo que marcam o contraste entre a magnificência da corte egípcia e a humilde condição a que são relegados nesta peça cada um dos heróis gregos que as contemplam. Subtraídos à matriz helénica, desenraizados do espaço que lhes confere a identidade e o elevado estatuto, cabe-lhes, em terra estrangeira, o papel que por tradição se destina ao bárbaro: «expulso da terra natal» (90), Teucro é o guerreiro proscrito, mais um entre os vencidos da guerra de Tróia; a rainha de Esparta,

${ }^{96}$ Embora os contactos entre a Grécia e o Egipto estejam já documentados desde as épocas minóica e micénica ( $v d$. B. Zweig, Women on the edge - Helen, New York, 1999, 230-31), o interesse dos Gregos pela civilização egípcia havia crescido consideravelmente com a divulgação dos escritos de Heródoto, que lhe dedica o Livro II das suas Histórias. Conhecida já como uma nação próspera e evoluída, "a grandeza do país dos faraós», segundo M. F. Silva ("Representações de alteridade no teatro de Eurípides: o bárbaro e o seu mundo", Génese e consolidação da ideia de Europa, Coimbra, 2005, 200), "não deixou de impressionar favoravelmente o povo da Hélade». Para mais, por tratar-se de um importante centro cultural onde alguns dos mais insignes sábios gregos haviam estudado, o Egipto surge, no imaginário grego, como "um local de mistério e sabedoria», bem distinto de outras terras bárbaras, agrestes e hostis, que Eurípides transforma em cenário de algumas das suas peças, a exemplo do que se verifica em $I T$. Não é, por esta razão, anódina a escolha do país do Nilo como espaço cénico de uma acção onde se diluem as diferenças entre Gregos e Bárbaros, conforme oportunamente demonstraremos. 
arrebatada à pátria por capricho divino, diz-se agora «escrava» em terras egípcias (275-76); e o outrora glorioso comandante do exército aqueu, em miseráveis andrajos de náufrago, vê-se forçado a mendigar o pão (789-91) e a suportar as humilhaçôes da velha porteira do palácio de Proteu (437-58), num espaço em que a xenia parece, por instantes, um princípio ausente.

Ao propor esta inversão dos pólos da antinomia grego-bárbaro, Eurípides não estaria, contudo, a assumir uma posição anti-nacionalista ou a demonstrar a superioridade dos povos não gregos em mais uma antilogia ao jeito sofístico, mas antes a redefinir o conceito de barbárie, provando o mero convencionalismo dos limites que separavam a Hélade de um mundo supostamente sem ordem nem lei. Só assim se explica que o processo de reabilitação do 'bárbaro' não dispense, em nenhum momento, o cotejo (quando náo a equiparaçáa) com o modelo grego, ficando mesmo a depender de alguns pressupostos subjacentes ao discurso e actuação dos heróis míticos da Hélade, que a tradiçáo literária havia convertido em ícones do triunfo da cultura grega sobre a barbárie. A súplica endereçada pelos reis de Esparta a Teónoe é talvez o exemplo mais expressivo deste movimento de "helenização» do universo não grego, que tende para a aproximação de duas realidades culturais em conflito. Não é, de facto, difícil constatar que toda a argumentação do par amoroso explora um código de valores de matriz helénica que sabe ser partilhado pela profetisa, a despeito da sua origem não grega. Se os heróis invocam os princípios da justiça e da piedade filial, o dever de acolher o estrangeiro e honrar os mortos, o direito conjugal e de propriedade e ainda o respeito pela vontade dos deuses, fazem-no convictos de que náo imperam na sociedade egípcia a injustiça, a crueldade ou a anomia que configuram o estereótipo do bárbaro. De modo análogo, quando se dirige ao palácio real na esperança de obter do seu senhor os favores da 
hospitalidade, Menelau prefere ver, na opulência das muralhas, a marca da civilidade tipicamente grega ao invés da perigosa ameaça de um povo dado ao luxo e ao excesso: «Ao ver este palácio cercado de muralhas e este imponente pórtico, indício da opulência do seu senhor, aproximei-me. Afinal, uma casa abastada promete aos marinheiros alguma benesse.» (430-33). Assim, mesmo tendo já aportado, na sua errância, a terras agrestes e inospitaleiras (404-405), não se apressa a associar a esta imagem padronizada da barbárie o país em que se encontra; antes reclama os direitos que lhe assistem enquanto "náufrago estrangeiro» (449), na presunção de que as normas básicas do convívio social são conhecidas dos habitantes daquelas ricas moradas. Estaria certo o herói, não fora a presença de Helena, que é, ironicamente, a única causa da hostilidade com que será recebido. Ora, o carácter excepcional deste acolhimento pouco amistoso de um estrangeiro deduz-se novamente da incompreensão que o próprio Menelau manifesta quanto à animosidade do soberano egípcio para com os Helenos (468-69). Para mais, a crença de que o seu nome célebre lhe promete uma recepção condigna por parte do faraó faz supor a existência de um relacionamento pacífico entre ambos os povos ${ }^{97}$. Não são, por isso, reflexo de uma atitude xenófoba as acerbas palavras da porteira, que, de resto, não omite a sua amizade para com os Gregos e tão-pouco se mostra desconhecedora dos preceitos da xenia:

«Se o meu senhor te descobrir, terás a morte como presente de hospitalidade. Da minha parte, sou complacente para com os Gregos e a rispidez das minhas palavras foi ditada pelo medo que tenho do rei.» (479-82).

${ }^{97}$ Cf. M. F. Silva (op. cit., 2005, 199): «[Menelau] espera mesmo que o seu nome lhe valha alguma compreensão, o que coloca o relacionamento da Grécia com o Egipto ao nível de uma relativa proximidade». 
Assim, quando expulsa Menelau das portas régias, a velha serva zela apenas pela segurança do estrangeiro, à semelhança do que fizera Helena ao advertir Teucro da ameaça que sobre ele impendia. Mas da hospitalidade egípcia é a protagonista quem sobretudo beneficia: mesmo após a morte de Proteu, que durante anos guardara o seu leito intacto para o esposo, todos no palácio real se mostram favoráveis à estrangeira, a quem oferecem proteç̧ão no momento em que decide abandonar o túmulo para consultar Teónoe (313-15). Todo o sinal de violência ou incivilidade reflecte, assim, o desvio à norma numa sociedade em que o nomos colectivo se náo confunde com os desmandos de um déspota cruel e sanguinário, disposto a sacrificar à paixão por Helena o legado de justiça herdado de Proteu.

Somente a alusão a Teoclímeno carreia, portanto, o tom de perigo iminente, que aos visitantes permanece imperceptível sob a acolhedora atmosfera de ordem e civilidade reinante nas margens do Nilo. Helena é a primeira a delinear o perfil de crueza e impiedade do soberano, que, em prejuízo da lei e da vontade paterna, se mostra disposto a recorrer à força a fim de satisfazer o seu desejo carnal. Mas é sobretudo quando a protagonista expóe a Teucro o motivo da ausência do seu perseguidor que aos olhos do público começa a tomar forma o retrato do bárbaro sanguinário, dominado por instintos primitivos:

«Está ausente, no momento; com os seus cães, move uma sangrenta perseguição aos animais selvagens. E - cautela! - que ele mata qualquer estrangeiro grego a que deite a mão.» (153-55).

A sugestáo de animalidade e selvajaria que perpassa estes versos, onde a referência à caçada de Teoclímeno metaforiza o feroz assédio ao leito de Helena e a perseguição decretada contra os seus potenciais raptores, será ainda corroborada aquando da 
entrada do soberano (1165-76). Neste quadro cénico, não é, pois, semanticamente irrelevante a presença dos cães e apetrechos de caça, elementos figurativos da perigosa armadilha que aguarda os Gregos desprevenidos e indefesos. Representa-se, assim, no plano imagético ${ }^{98}$, a temida agressão bárbara ao nomos e à soberania helénica, que justifica o conflito indissolúvel entre estes dois hemisférios político-culturais.

À margem do modelo de virtude em que se enquadram o piedoso Proteu e a filha Teónoe, dona de uma sapiência que a equipara à própria Atena ${ }^{99}$, Teoclímeno destaca-se como contra-exemplo dos ideais de justiça e moderação que os Gregos consideravam pilares de uma civilização evoluída e superior. Rosto da bestialidade primitiva e de uma irracionalidade não refreada pelos limites da lei, o tirano egípcio encarna, assim, os vícios que definem o protótipo do náo-Grego, ao mesmo tempo que abre caminho a uma retórica de promoção das instituições político-sociais helénicas, de que a tragédia é fecunda. Afinal, não é difícil perceber, por detrás de uma censura evidente ao sistema monárquico vigorante em terras egípcias, o orgulhoso elogio da democracia grega, que Helena sugere ser garantia da liberdade dos cidadáos:

«Aqui, privada dos meus entes queridos, fui feita escrava, apesar de haver nascido livre. Afinal, à excepção de um, todos os Bárbaros são escravos.» (274-76).

A crítica que recaía indistinta e acriteriosamente sobre todos os aspectos do mundo dito bárbaro direcciona-se agora apenas

${ }^{98}$ A respeito da imagética venatória associada à personagem de Teoclímeno, vd. E. Hall, op. cit., 113.

${ }^{99}$ D. Sansone (op. cit., 18-25) argumenta desenvolvidamente a favor desta identificação entre a deusa Atena e a personagem de Teónoe, a quem se confere, assim, uma dignidade quase divina. 
ao regime não democrático, assim representado pelo poder tirânico exercido por Teoclímeno.

No entanto, mesmo se o soberano é o espelho da imagem preconcebida que o Grego possuía do Bárbaro e que a literatura convertera num topos, a sua actuação não invalida a proposta de nobilitação do mundo bárbaro que se esboça nesta tragédia. Afinal, como antes se disse, a conduta do tirano náo faz regra num espaço em que estão bem presentes os princípios elementares do convívio humano e as leis básicas de organização social. Em rigor, nem mesmo a própria personagem de Teoclímeno parece exemplificar na plenitude a divisáo radical dos universos grego e bárbaro, perspectivados como duas realidades opostas na escala do progresso civilizacional. Confirma-o o respeito demonstrado pela condiçáo de suplicante da Espartana, que não ousa arrebatar pela força ao túmulo de Proteu, e corrobora-o a devota prece dirigida ao pai, aquando da sua entrada em cena. Mas importa sobretudo sublinhar o espírito tolerante do rei, que náo impede o cumprimento dos rituais fúnebres de Menelau segundo o que supóe ser o costume helénico, numa pacífica aceitação das diferenças de nomos existentes entre Gregos e Egípcios. Não é, pois, a simples obediência a um padrão de comportamento tipicamente bárbaro que justifica a irracionalidade de Teoclímeno, mas o poder inelutável da paixão, a que nenhum dos mortais está imune.

A violência do tirano enamorado e os obstáculos que coloca à (re)união do par amoroso assistem, portanto, acima de tudo, às exigências de uma intriga de feição romanesca, que náo dispensa, entre um número mais ou menos fixo de ingredientes, a figura do viláo cruel, empenhado em impedir o amor dos heróis. Na peça de Eurípides, contudo, Teoclímeno transita rapidamente da condição de agressor temível para a situação de vítima ingénua do estratagema congeminado por uma mulher. Estaria Eurípides a retomar o estereótipo grosseiro do bárbaro 
bronco e estulto, opondo-o à imagem idealizada do grego intelectualmente superior? ${ }^{100}$ Dois argumentos infirmam esta interpretação: por um lado, a tradição não é parca em exemplos de heróis helénicos caídos em desgraça por obra de ardis femininos ${ }^{101}$; por outro, a ingenuidade do bárbaro Teoclímeno nâo fica aquém da inépcia momentos antes evidenciada por Menelau, que se revelara incapaz de delinear um plano de fuga eficaz. O dolo de Teoclímeno ou o sucesso da maquinação de Helena não ficam, por isso, a dever-se à estultícia do bárbaro, mas tăo-só ao habilidoso aproveitamento que faz a Espartana de uma diferença de nomoi entre Gregos e Egípcios. De facto, fingindo chorar a morte do esposo ali oculto sob os andrajos de náufrago, a Tindárida logra convencer o faraó de que tudo quanto necessita para a fuga - armas de bronze (1263), um barco e remadores (1267), uma rês sem defeito (1259) e «o que a terra produz de melhor» (1265) - se destina ao cumprimento do ritual fúnebre celebrado, segundo o costume grego, em honra dos que morrem no mar. E a cada manifestação de estranheza e desconfiança do bárbaro, decidido a impedir a participação da viúva na homenagem ao morto, os heróis respondem com o mesmo argumento: as exigências e particularidades do nomos grego. Contudo, para o bárbaro ainda renitente em aceitar tal diferença de costumes, o apelo à piedade e ao dever de honrar

${ }^{100}$ Já documentada em Hdt. I, 60, a crença na superioridade intelectual dos Gregos sobre os demais povos deve-se, de acordo com E. Hall (op. cit., 200), à associaçáo directa entre a inteligibilidade do discurso e o perfeito domínio da razão. A identificação de ambos os conceitos, verbalmente representados pelo signo logos, justifica, por isso, a inferiorização do bárbaro, cuja língua imperceptível é sugestiva de um pensamento incoerente. Segundo esta lógica, faz, assim, todo o sentido que a heroína recorra à arte do logos, bem conhecida das sociedades democráticas, para manipular com êxito o tirano egípcio.

${ }^{101}$ Agamémnon é talvez o exemplo mais flagrante do herói grego vítima da perfídia feminina. 
os mortos revela-se, sugestivamente, decisivo, tanto mais que ao rei fora negado, até ao momento, o carácter pio e natureza nobre que o seu nome e ascendência reclamam:

Menelau: Exige a piedade que se não prive os mortos das honras que o costume prescreve.

Teoclímeno: Que vá, então: é-me conveniente cultivar a piedade da minha esposa. (1277-78)

A polarização Grego-Bárbaro parece, assim, reequacionar-se à luz de uma outra antinomia bem cara à sofística: physis/nomos. Irmanados por uma natureza comum, Gregos e náo-Gregos reduzem as suas diferenças às especificidades das leis e costumes que observam. E destas particularidades, com que Eurípides vai pontuando o texto, não parece resultar qualquer desprimor para o mundo não helénico, assim como a elas se não fica a dever a confirmação da superioridade da cultura grega. De resto, para encurtar a distância entre os dois pólos da dicotomia, o trágico reduz ao nível do pormenor mais irrelevante as diferenças de nomos que os separam: um túmulo cumpre, em terras egípcias, a função de um altar para o suplicante grego (800-801); a presciência dos oráculos encontra equivalente nos dons proféticos de Teónoe, ainda que a sua entrada em cena descreva um ritual egípcio ${ }^{102}$, distinto dos ofícios da religiâo grega; e em ambas as culturas, a cerimónia fúnebre não dispensa o sacrifício de um animal, mesmo que, «entre os Bárbaros» - conforme especifica Teoclímeno - seja «costume imolar um cavalo ou um touro». (1256-58). Em

${ }^{102}$ A entrada em cena de Teónoe, precedida de um cortejo de servas que purificam o caminho com fumigaçôes de incenso, retrata uma prática dos sacerdotes egípcios, descrita em Plu., Mor., 79 (cf. E. Hall, op. cit., 146). 
abono da verdade, nenhuma das tradiçóes gregas se mostra completamente alheia às habituais práticas egípcias, o que explica a estranheza de Teoclímeno face ao suposto costume helénico de sepultar em cenotáfio um corpo ausente. Coincide, portanto, com o engano forjado pelos heróis a maior das diferenças assinaladas entre o nomos helénico e o egípcio, sugestão clara do carácter ilusório da crença na intransponibilidade das barreiras culturais que separam o mundo grego do não grego.

Há, por outro lado, momentos em que as diferenças entre Gregos e Bárbaros vivem apenas de frágeis estereótipos, que Eurípides subtilmente desconstrói. O luxo e opulência tradicionalmente atribuídos aos povos bárbaros, como marca de uma tendência para a ostentação e exibicionismo, são apenas um exemplo de signos de barbárie convertidos na peça em simples indicadores de classe/estatuto social ou mesmo, como antes vimos, em indício de uma prosperidade que acompanha a dádiva generosa. Com efeito, tal como as magnificentes muralhas do palácio egípcio, também a prodigalidade de Teoclímeno ou os ricos rebanhos a que alude o soberano, cuja «lauta mesa» Helena recusa partilhar (295-96), não encontram o seu reverso numa esperada sobriedade e despojamento dos heróis gregos. Basta recordar que os primeiros sinais de riqueza com que se depara Menelau sáo suficientes para acordar no íntimo do guerreiro a memória do seu passado de glória e, com ela, o doloroso pesar pela perda dos ricos peplos, das vestes sumptuosas e dos demais ornamentos (423-24) que lhe garantiam o reconhecimento do seu estatuto régio.

Assim, ao contrário de Ésquilo ou mesmo de Sófocles, que enveredam por uma recriaçáo realista do mundo náo grego, representando com rigor as suas paisagens, hábitos e costumes, bem distintos dos helénicos, o autor da Helena prefere, como se disse, o caminho da discussão de ideias, pelo que atribui às referências 
geográficas e etnográficas um valor simbólico ${ }^{103}$, concordante com a linha temática desenvolvida na tragédia. Com efeito, a escolha de um cenário exótico, onde avulsamente vão surgindo elementos estranhos ao espaço físico e cultural da Hélade, parece conformar-se com a sua intenção de representar a face encoberta de uma realidade que se não pretende unívoca e unidimensional. Ao transportar o público para um outro ambiente onde, com as personagens, ele é desta vez o estrangeiro, o trágico propóe um novo conceito de alteridade, segundo o qual 'grego' e 'bárbaro' são termos reversíveis.

Neste sentido, à medida que a acção se aproxima do desenlace, com a fuga do par amoroso a tornar-se uma realidade iminente, o espectador assiste a uma progressiva 'barbarizaçáo' dos heróis da Hélade, que equilibra com o já descrito movimento de helenização do mundo bárbaro.

De facto, o sucesso do estratagema de Helena, que assegura aos reis de Esparta a recuperação da sua verdadeira identidade, parece depender já não do confronto, mas do encontro com o bárbaro. No plano cénico, esta convergência é, antes de mais, sugerida pela movimentaçáo das personagens. Inicialmente, é a profetisa bárbara quem transpóe as muralhas do palácio e se acerca dos heróis gregos, uma aproximação que traduz o estreitamento da distância entre os dois mundos em aparente conflito. O resultado, a harmonização das personagens, fica, portanto, a dever-se à helenização da princesa egípcia, em cuja sentença ecoam nitidamente os princípios basilares da

${ }^{103}$ Dando conta das principais diferenças entre os principais tragediógrafos no concerne ao tratamento do tema do Bárbaro, refere H. Bacon (Barbarians in Greek Tragedy, New Heaven, 1961, 168-71) que «enquanto Ésquilo e Sófocles são realistas» na representação fiel de costumes, paisagens, indumentária e outros objectos de valor etnográfico, «Eurípides é temático ou simbólico", facto que não denota um desconhecimento do mundo não grego mas tão só uma opção poética. 
moral grega. Inversamente, porém, o apaziguar do conflito que opóe Teoclímeno aos heróis gregos tem origem numa dolosa maquinaçấo, em tudo semelhante à que já antes dera vitória aos Aqueus sobre os Troianos. Mais uma vez, o primeiro passo para o êxito do plano dar-se-á com a entrada dos Gregos nos domínios da barbárie: inicialmente, é apenas Helena quem se adentra pelo palácio bárbaro, a fim de trocar as vestes por trajes de luto e preparar-se, assim, para o temível confronto com o tirano egípcio; pouco depois, vencida a oposição do soberano, é a vez de Menelau entrar nas moradas reais, onde se reconverte no guerreiro coroado de triunfo. Sáo, pois, o disfarce, a perfídia e a astúcia, tradicionalmente associados ao bárbaro e em particular ao povo egípcio ${ }^{104}$, que acabam por garantir o regresso dos heróis a Esparta. Neste contexto, as imponentes muralhas do palácio - claramente evocativas da magnificente cidadela de Tróia - prefiguram as fronteiras que separam o espaço helénico de um mundo que o espectador ateniense até entâo lhe considerava alheio, senão antagónico. Sugestivamente, porém, é no interior destas moradas reais, junto às quais Teucro e Helena haviam buscado respostas para o futuro e Menelau o conforto para as suas misérias, que o Atrida recupera a sua identidade de herói homérico, assegurando o regresso à pátria e a reposição da verdadeira identidade da rainha de Esparta. Não é, por isso, desprovida de simbolismo esta "ocupação" do espaço bárbaro pelos heróis da Hélade: por um lado, ela sugere a função referencial do conceito de barbárie no processo de auto-definição da cultura helénica ${ }^{105}$; por outro, antecipa a imagem "barbari-

${ }^{104}$ Segundo E. Hall (op. cit., 214), «treachery, cunning, duplicity (...) are familiar themes from rethoric against the barbarians». Nesta moldura global, os Egípcios tipificariam particularmente a astúcia, a perfídia, um carácter arteiroso e enganador (ibid., 123).

${ }^{105}$ Em confirmação da tese sustentada por E. Hall (op. cit., 1), que entende o retrato do bárbaro na literatura grega como «um exercício de 
zada" dos Helenos, a que o violento quadro da fuga dará cabal expressão.

$\mathrm{Na}$ verdade, o massacre dos marinheiros bárbaros, com os pormenores de crueldade que o colorido relato do mensageiro não omite, vem perverter a imagem arquetípica do Grego diplomático e civilizado, paladino da justiça e defensor das relaçôes pacíficas entre povos. Se o hábil manejo do logos (considerado o amplo espectro semântico do termo: palavra, discurso, pensamento), à boa maneira helénica, fora antes a solução encontrada para contornar a ameaça do tirano, são as armas do inimigo - não apenas num sentido literal - que Menelau e os companheiros usam agora para neutralizar a oposiçẫo bárbara. Ao comando de um navio fenício e ostentando as armas de bronze que lhe oferecera o rei egípcio, o Atrida reveste a imagem do bárbaro impiedoso, que ordena a chacina cobarde e desleal de um adversário inerme, incapaz de apenas com tábuas e remos, oferecer resistência às espadas gregas (1600-1601). E à própria Espartana, que pouco antes chorava o desastre de Tróia, lamentando as mortes causadas por uma guerra vâ, vemo-la incitar vigorosamente os homens de Menelau, invocando a glória por estes alcançada nas margens do Escamandro. O combate final, espelho da destruiçăo de Ílion, também ela resultado do ardil de um grego, conota a acção dos heróis com um padrão de comportamento caracteristicamente bárbaro, pautado por uma violência injustificada,

auto-definição», Eurípides sugere a importância que assume o conceito de barbárie na construção da identidade do povo helénico. No entanto, se, em abstracto, o bárbaro se assume como negativo do ideal grego, na prática, como pretende o trágico demonstrar, não existe um referencial nem sequer um limite geográfico ou étnico que corresponda a este anti-modelo cristalizado pela tradição épico-trágica. Assim se explica que a recuperação do estatuto e identidade dos heróis se consiga pela harmonizaçáo mais do que pelo recontro (ou oposição) com o adversário bárbaro, convertido, deste modo, em adjuvante do par amoroso. 
que serve mais a orgulhosa demonstração de poder do que a simples necessidade de auto-defesa.

Neste cenário em que é o agir e já não a proveniência, a ética e não a etnia, o critério de definição do bárbaro, o objectivo de Eurípides ganha, assim, maior consistência e nitidez. Com a reconceptualização do termo, o trágico faz-se de novo porta-voz do relativismo sofístico, provando, numa primeira instância, a fragilidade de toda a postura etnocêntrica. Diante de uma Hélade fechada sobre si mesma na defesa intransigente da sua superioridade, representa, assim, a imagem - real ou ilusória? - de um povo que paga os favores da hospitalidade egípcia com o sangue de inocentes. ${ }^{106}$ Num sentido mais amplo, todavia, a Helena euripidiana desmascara toda a sorte de preconceitos fundados sobre as bases da convenção, abolindo as fronteiras que desunem o género humano, comparticipante, afinal, de uma natureza comum. Só assim encontra sentido e pertinência o diálogo final entre o servo de Teoclímeno, dono de uma sensatez e comedimento dignos de homem livre, e o seu senhor, a quem faltam o auto-domínio e o senso de justiça que um carácter nobre não dispensa.

O desfecho da peça vem, desta feita, consagrar a aproximação de Gregos e Bárbaros, Livres e Não Livres, com a intervenção dos Dioscuros a sanar as divergências entre as partes em conflito e a sugerir, sob o signo da sofística, o carácter artificial de uma divisão contra natura...

${ }^{106} \mathrm{Hdt}$. II, 112-120 refere também a impiedade que assiste ao sacrifício de jovens egípcios, ordenado por Menelau antes do regresso. Preocupado em obter ventos favoráveis para a viagem, o Atrida desonra, assim, a hospitalidade com que fora acolhido no regresso de Tróia pelo rei do Egipto. O paralelo entre ambas as versôes - a dramática e a historiográfica - parece evidente, insinuando a existência de um fundamento real para a ficção e reforçando o jogo dramático em torno dos conceitos de verdade e ilusão. 


\section{UMA TRAGÉDIA DE IDEIAS}

No universo de questóes que continuam a alimentar intermináveis debates entre os críticos da obra euripidiana, uma das menos consensuais será talvez a da classificação genológica da Helena, habitualmente - e de forma pouco justa, a nosso ver - relegada à categoria de "obra menor"107. Apenas a ousada independência face ao modelo canónico de tragédia continua a justificar o lugar secundário ainda ocupado por uma obra que, fruto de uma concessão do autor ao espírito de mudança do seu tempo ${ }^{108} \mathrm{e}$ às novas ideias que pululavam no meio intelectual, se apresenta como desenvolvimento completo, maduro e arrojado de um conjunto de experiências já ensaiadas em peças anteriores. De comédia ${ }^{109}$ a tragicomédia, ${ }^{110}$ de paródia ${ }^{111}$ a drama

${ }^{107}$ I. Holmberg (op. cit., 39) dá conta daquela que é a posição geral dos críticos: «...Euripides creates a play which has not entered the ranks of those considered among his greatest.»

${ }^{108} \mathrm{Vd}$. C. Morenilla, "La Helena de Eurípides", O mito de Helena: de Tróia aos nossos dias, Coimbra, 2006, 184.

${ }^{109}$ A classificaçáo é proposta por diversos autores, a exemplo de A. Burnett ("Euripides' Helen: a Comedy of Ideas", CPh 55, 1960, passim), H. D. F. Kitto (A tragédia grega, Coimbra, 1990, 314), G. Grube (The drama of Euripides, London, 1941, passim), E. Turolla, ("Commedie tragiche nel teatro euripideo", PP 8/2, 1953, 82), L. Biffi ("Elementi comici nella tragedia greca', Dioniso 35, 1961, passim).

${ }^{110}$ Vd. E. Barnes, "Greek tragicomedy", CJ 60, 1964, 125-31.

${ }^{111}$ H. Grégoire (Euripide. Hélène, Les Phéniciennes, V, Paris, 1961, 38), apropriando-se de uma expressão de A. W. Verrall, alude à tragédia como "un centon de parodies". O tom parodístico da peça é ainda assinalado por B. Zweig (op.cit., 237), embora seja de notar no seu texto uma certa arbitrariedade - já de resto observada em outros autores - no uso dos termos 'paródia', 'sátira' e 'comédia', cujo dividendo comum é o humor. 
romanesco ${ }^{112}$, a Helena tem merecido as mais diversas classificaçôes, ao passo que o estatuto de tragédia, nunca questionado pelos contemporâneos de Eurípides ${ }^{113}$, lhe tem vindo a ser recusado por um número cada vez maior de autores, possivelmente preocupados em ressalvar a sua especificidade ou originalidade no conjunto da obra do trágico. De acordo com Podlecki, é visível, sobretudo entre os críticos recentes, uma acentuada propensão para situar a obra nas fronteiras da comédia ${ }^{114}$. Muito embora não constitua um ataque à habilidade de Eurípides enquanto dramaturgo, até porque acompanha geralmente a ideia de que teria sido propósito deliberado do autor testar os limites do género mediante a criação de "algo de novo»" ${ }^{115}$, à margem da tragédia, a verdade é que esta posição compromete

${ }^{112}$ Segundo H. Grégoire (op. cit., 38-39), esta é a linha de interpretação seguida sobretudo pelos estudiosos do folclore e do romance grego, que integram a Helena no conjunto de peças euripidianas de teor romanesco. A. Rivier (apud M. Dirat, "Le lyrisme d'Hélène", REG 89, 1976, 17) vai mesmo ao ponto de considerar que a Helena apresenta «le romanesque à l'état pur».

113 Segundo A. Lesky (História da Literatura Grega. Tradução de Manuel Losa, Lisboa, 1995, 415-16), o problema do género da Helena só pode colocar-se no âmbito de uma discussão moderna do conceito de tragédia, já que um grego contemporâneo de Eurípides jamais questionaria este estatuto a uma obra representada nas Dionísias e subordinada a um tema mitológico.

${ }^{114} \mathrm{Vd}$. A. Podlecki, "The basic seriousness of Euripides' Helen”, TAPhA 101,1970, 40: «...the emphasis of most recent criticism has fallen heavily on the side of the comic».

${ }^{115} \mathrm{Vd}$. A. Rivier (Le tragique d'Euripide, 1975, apud J. Romilly, op. cit., 1986: 38). Outros autores, entre os quais I. Holmberg (op. cit., 38), partilham da opiniáo de que o interesse de Eurípides seria o de testar os limites do género, mediante a sua subversão. A. Burnett (op. cit., 1960, 154), por sua vez, parece acreditar que o trágico ateniense se desvia conscientemente da tragédia, numa incursão experimental pelo campo da comédia: «Far from being a tragedy gone wrong, the Helen is an experiment in a new sort of comedy (...).». A autora (Catastrophe survived: Euripides' plays of mixed reversal, Oxford, 1971, 85) afirma ainda que, na Helena, Eurípides «is not simply dancing on the grave of the genre he has outraged, but looking for a new mode of expression for another kind of thought». 
em larga medida a seriedade que lhe é inerente. Por este motivo - e sem que se queira escamotear a presença na peça de determinados traços e clichés típicos da comédia, ou mesmo o filáo fantasista do argumento -, torna-se essencial ressalvar os pressupostos filosóficos e as implicaçôes dramáticas subjacentes a determinados temas, situaçôes, quadros e opçôes cénicas, que uma análise superficial reduz ao puro burlesco.

No que ao pretenso recorte cómico da peça diz respeito, a argumentação da crítica parece incidir com especial insistência sobre a personagem de Menelau, que já Blaicklock ${ }^{116}$ afirmara invariavelmente vilipendiada na obra euripidiana.

Logo no seu monólogo inicial, a evocação da genealogia nobre e a orgulhosa lembrança do contributo dado à empresa troiana, ao lado de um Agamémnon que perde claramente o protagonismo conquistado na épica, têm contribuído em larga medida para a leitura do seu discurso como um cortejo de ocas fanfarronadas, bem de feição com o tipo cómico do miles gloriosus $^{117}$. Curiosamente, porém, os mesmos autores que vêem nesta cena uma distorção jocosa do ideal guerreiro celebrado por Homero e em Menelau o anti-herói capaz de mascarar a real debilidade sob um discurso de falsa valentia, não salientam idêntico potencial cómico no monólogo inicial de Helena,

${ }^{116}$ No capítulo dedicado ao marido de Helena, E. Blaicklock (The male characters of Euripides. A study in realism, Wellington, 1952, 74-100) analisa o perfil e actuaçáo da personagem no conjunto do repertório euripidiano e, sem excluir o Menelau recriado na peça em estudo, conclui, na senda de Aristóteles (Po., 61b), acerca do tratamento aviltante que a figura do Atrida merece por parte do trágico.

${ }^{117}$ A expressão surge em Blaicklock (op. cit., 92), G. M. A. Grube (op. cit., 339), J. G. Griffith ("Some thoughts on the Helena of Euripides", JHS 73, 1953, 36). N. Marini ("Il personaggio di Calliroe come "nuova Elena' e la mediazione comica di un passo euripideo", SIFC 11, 1993, 212-13) chega mesmo a enumerar um conjunto de semelhanças ao nível da estrutura, personagens e motivos dramáticos entre a comédia plautina Miles Gloriosus e a tragédia de Eurípides. 
mesmo admitindo o evidente paralelo existente entre ambas as sequências dramáticas. A nós parece-nos, contudo, que, se a alusão à ascendência divina da Espartana visa a integração do destino da personagem numa espécie de cadeia hereditária de enganos, a referência ao terrível fim de Pélops, ilustre antepassado do Atrida, deverá interpretar-se como semelhante justificativa para a miséria presente do herói e não como simples contributo para um suposto discurso de auto-exaltação. $\mathrm{Na}$ mesma ordem de ideias, se o comiserado lamento de Helena pela identidade perdida e pela reputaçáo injustamente maculada logra concitar a compaixão do público, nenhum argumento razoável pode justificar a leitura das palavras condoídas do rei de Esparta, que, em trajes de náufrago, recorda pesarosamente as honras (417-18) e riquezas perdidas (420-24), como alarde balofo das glórias do passado. ${ }^{118}$ Assim, a apresentação de Menelau como comandante máximo do exército grego, subvertendo o retrato convencional do herói cobarde que colhe louros na sombra das façanhas do irmão, apenas repete uma manobra dramática já actualizada no discurso de reabilitação da nova Helena, cuja imagem de fidelidade, não menos surpreendente aos olhos do público, está longe de cumprir uma finalidade humorística.

Porém, não é apenas no monólogo inicial de Menelau que os críticos divisam esta imagem do guerreiro poltrão e ufano. A evocação, no diálogo com a porteira, do seu célebre exército (453) e dos prósperos êxitos do passado (457), tópicos de resto retomados na cena de Teónoe $(949,970-71)$, são também

${ }^{118}$ Cf. A. Podlecki, op. cit., 405: «Menelau's preoccupations manifested in his opening scene correspond closely to those already voiced by Helen herself (...)». Se a esta afirmação associarmos a de Grube (op. cit., 335), que apresenta o patético lamento de Helena como «the only really tragic emotion of the whole play - in its full pathos and intensity», náo nos resta outra inferência senão a de que a entrada de Menelau dificilmente admite uma leitura cómica. 
citados pelos partidários de uma leitura cómica da peça, que assinalam o grotesco contraste das palavras orgulhosas do destruidor de Tróia com a atitude piegas de um homem lamentoso, em lágrimas, que se submete resignadamente à rispidez de uma serva bárbara. Não nos parece, contudo, que estes dados sejam pertinentes para concluir da feição puramente cómica da cena, embora, sem dúvida, relevantes na definição da ambiguidade da personagem e, consequentemente, na problematização das antíteses onoma-pragma e aparência-essência ${ }^{119}$. Na verdade, o traço realista com que Eurípides recria a figura do Atrida não colabora necessariamente, como pretende Blaicklock ${ }^{120}$, no aviltamento e ridicularização da personagem; antes realça a faceta humana do guerreiro, cuja sensibilidade se sobrepõe à máscara de euandria envergada pelos heróis de Homero $^{121}$, em que a tragédia por norma colhia inspiração. Um agudo entendimento da psicologia humana, consensualmente reconhecido a Eurípides, bastaria, assim, para justificar a divagaçâo nostálgica do rei de Esparta, que compensa com uma reconfortante lembrança dos tempos de glória a humilhação de que é vítima por parte da velha egípcia. Idêntica explicação têm as lágrimas de Menelau que, bem expressivas da dimensão do pathos experimentado, o irmanam em sofrimento com a protagonista, num reforço do paralelo

${ }^{119}$ A questão fora pela primeira vez aflorada no discurso introdutório de Helena, que náo pode perder-se de vista na leitura do monólogo de Menelau.

${ }^{120}$ Op. cit., 74.

121 Não seria difícil enunciar um conjunto de passos da epopeia homérica em que heróis como Ulisses choram de comoção ou tristeza ao relembrarem as glórias e alegrias do passado (e.g. Od. 8. 523-31). Julgamos, contudo, importante ressalvar que a imagem de um herói tomado pela emoção não é em Homero recorrente, mas pontual. Desta feita, o que faz Eurípides é salientar a face sensível do guerreiro, que na poesia épica se esbate perante a imagem dominante do herói inflexível, imperturbável perante as adversidades, movido mais pela honra do que pela emoçáo. 
estabelecido ao longo da acção entre ambos os heróis. Com efeito, o que, numa primeira instância, aproxima as figuras de Helena e Menelau, tornando efectiva a simetria que o autor plasmou na construção das cenas, é, quanto a nós, a nota de tragicidade que marca o seu destino. Vítimas do capricho dos deuses, ou, em última análise, de uma ilusão, ambas as personagens ilustram cabalmente a impotência do homem face a uma realidade que não pode com clareza conhecer e, logo, dominar. Assim, longe da pátria, destituídos da verdadeira identidade, reduzidos a servos ou a mendigos, à mercê da misericórdia ou dos desmandos de reis bárbaros, os soberanos de Esparta, caídos em desgraça (417-19), mais depressa suscitariam o terror e a piedade ${ }^{122}$ do que o riso no seio de uma audiência que reconhece na saga dos heróis o trajecto da história recente da Hélade. A própria missão catártica da tragédia parece cumprir-se nesta figuração teatral de uma Grécia fragilizada por inúteis conflitos internos e derrotada pela nebulosa ilusáo que a riqueza siciliana representara, uma nação onde as mulheres chorariam ainda a perda dos entes queridos em guerras sem sentido e os sobreviventes se vergariam sob uma humilhação indigna das vitórias do passado.

No entanto, a despeito do que se afirma em defesa da faceta trágica do herói, não podemos deixar de notar que há, no diálogo com a porteira, um momento em que o retrato do líder decaído, levado ao extremo, raia mesmo os limites da caricatura. De facto, com a humilhação verbal a descambar em agressão física, nada poderia comprometer mais a austeridade da cena do que a frouxa resposta de Menelau ao empurrão da anciá rude e mal-humorada, em que o público imediatamente reconhece a

${ }^{122}$ Esta é também a opiniăo de L. A. Post ("Menander and the Helen of Euripides", HSCP 68, 1964, 117): "There is indeed pity and fear for the abused hero and heroine, who are confronted by the danger of death or dishonour.». 
velha criada bêbada e desbocada da comédia. Ora, esta concessão do trágico ao cómico não se faz sem anúncio prévio; condicionado por um amplo conhecimento do modelo cómico e dos topoi em que invariavelmente reincide, o espectador prepara-se para uma mudança de tonalidade no momento em que o Atrida bate à porta do palácio na intenção de suplicar aos seus senhores o auxílio necessário para continuar viagem. De facto, uma porta prestes a abrir-se gera inevitavelmente uma empolgada expectativa quanto às revelaçôes que um terreno até aí vedado à visão permite especular; ao mesmo tempo, para um público experiente, convoca a lembrança de um considerável número de cenas aristofânicas, onde o insólito e o absurdo atendem como condimento essencial da piada. ${ }^{123}$ No entanto, no cenário da $\mathrm{He}$ lena, a porta não é simplesmente mais um elemento de cómico, mas marca a divisão entre dois espaços antagónicos, o grego e o bárbaro, a revelação e o engano e, nesta sequência dramática em particular, também a fronteira entre o trágico e o cómico, que, como opostos, se tocam ${ }^{124}$. Uma interpretaçáo radical da cena - ou da peça, por extensão -, quer pendendo para o seu cariz puramente cómico, como parece ser a opção da maioria dos estudiosos, quer inclinada para uma linha trágica, que não

${ }^{123}$ M. F. Silva ("A porta na comédia de Aristófanes. Uma entrada para a utopia", Ensaios sobre Aristófanes, Lisboa, 2007, 257-74, passim) analisa desenvolvidamente o significado deste motivo cómico em diversas peças aristofânicas.

${ }^{124}$ De acordo com E. Barnes (op. cit., 125), «...the tragic and the comic, like all extremes, tend to pass into one another. This happens not because they are basically the same, but because they derive from radically different attitudes toward a single object.». Ao apresentar o trágico e o cómico como visôes extremas e opostas sobre uma mesma realidade, o autor lança uma pista para a leitura desta e de outras cenas de tom mais ou menos ambivalente, nas quais Eurípides, mesclando ou alternando elementos próprios da tragédia e da comédia, torna indefinidas as fronteiras do género e o submete a toda uma dialéctica de contrários já representada no argumento. 
admite o mais ténue traço de ridículo ${ }^{125}$, só pode, quanto a nós, desvirtuar o propósito original de Eurípides, que desde os primeiros versos recusa posiçóes unívocas, numa intransigente defesa da natureza ambígua ou mesmo contraditória de todo o real.

No entanto, a inversão de papéis entre a serva bárbara e o rei grego não deve ser entendida como mera reprodução de um topos recorrente na comédia, onde não raro o servo castiga o senhor ou o valentão se descose em receios e fragilidades perante um interlocutor pretensamente mais fraco. Sob a ligeireza de um motivo que é inegavelmente gerador de cómico, o tragediógrafo ateniense compóe em cena uma nova escala de valores, contrária à vigente, onde a visão "helenocêntrica" claudica e o orgulho bélico dá lugar a um pragmático espírito de sobrevivência, onde o nomos social surge ameaçado e a mulher redefine o seu lugar num opressivo mundo de valores másculos.

Dando sobretudo conta do espírito subversivo que atravessa o drama, o esquema é retomado em cada cena apenas com ligeiras cambiantes de sentido. Não é, pois, de estranhar que o mesmo Menelau que se apresentara como novo Ulisses em atribulada missão de regresso venha a revelar-se, após o reencontro com a sua Helena-Penélope, o perfeito contraponto do herói dos mil artifícios. Decidido a honrar as gestas troianas num confronto directo com o rival, o rei de Esparta é, de facto, tomado de um entusiasmo heróico $(808,812,814)$ que só a presença de espírito da Tindárida consegue refrear: «Não tens saída. O que precisas é de um estratagema.» (813). Impreparado para desafios e confrontos onde a retórica - não a espada - é a arma por excelência, onde a argúcia se sobrepóe ao combate armado, Menelau

125 Esta parece ser a posição sustentada e desenvolvida por autores como Podlecki (op. cit., passim) e M. O. Pulquério (op. cit., 219-20). 
coloca-se nas mãos da consorte que, dona de uma perspicácia não inferior à do próprio Ulisses, consegue sem dificuldade a adesão do marido à primeira parte do seu plano. De novo - e náo de forma arbitrária - é uma mulher que toma o lugar da frente. E fá-lo porque as armas conhecidas pelo guerreiro voltam a provar-se ineficazes num mundo regido por novos valores.

Dando consistência ao relativismo axiológico que começa a tomar forma no diálogo de Menelau com a porteira, a cena de Teónoe repete de algum modo esta inversão de papéis. Em foco, volta a estar o confronto entre Gregos e Bárbaros - com os segundos a assumirem uma autoridade que o teatro tornara apanágio dos primeiros -, e ainda um rígido código de conduta, que coloca em campos separados homens e mulheres, em mais uma expressiva dicotomia a animar a dinâmica filosófica da peça. Lembremos que, pouco depois de ter afirmado que «só uma mulher pode entender-se com outra» (830), o Atrida volta a assumir esta divisão entre sexos, que não só o impede de suplicar directamente à profetisa $(947,959-61)$, como o inibe de recorrer às lágrimas, expediente tipicamente feminino e, portanto, pouco adequado a um homem de armas. Mais uma vez, contudo, Menelau acaba por resvalar na emoção - ou, pelo menos, por fazer-lhe uma cedência estratégica ${ }^{126}$-, contrariando o firme propósito inicial de apelar à bravura e ao auto-domínio, conforme conviria a um vencedor de Tróia (948-49). Não é, contudo, a

${ }^{126}$ A respeito das lágrimas de Menelau, apresenta M. Dirat ("Le personnage de Ménélas dans Hélène”, Pallas 23, 1976, 14-15) uma interpretação interessante, que nos permite ler toda a actuação do Atrida como parte de uma estratégia cuidadosamente estudada para garantir a adesáo da profetisa, na qual a retórica tem um papel decisivo. Começa o autor por assinalar a estrutura circular do discurso de Menelau, que recusa, na peroração e no exórdio, o apelo à emoção, e conclui afirmando que o herói actualiza o procedimento retórico da preteriçáo, quando transforma a piedade num ponto forte do seu discurso, justamente com a promessa de não recorrer às lágrimas. 
honra ou sequer a virilidade da personagem que vemos comprometidas no momento em que reprime - ou finge reprimir - as lágrimas (991-92). De resto, o próprio Menelau - numa tirada em que a voz de Eurípides soa em defesa da dignidade das suas personagens - se encarregara previamente de enquadrar esta expressão de sensibilidade nos padrōes de elevação moral que definem um herói trágico, quando afirma: «Dizem, é certo, que é próprio de um homem nobre derramar lágrimas na adversidade.» (950-51).

Desta feita, o que ao público se apresenta é apenas a imagem do guerreiro manietado, que o autor desloca de um universo ilusório de glórias beligerantes para uma realidade onde as armas náo garantem nem a fama nem a vida e onde cabe às mulheres decidir o destino dos homens. Ora, se o objectivo de Eurípides não passa por explorar a faceta débil e efeminada do herói, com os efeitos cómicos que a caricatura certamente produziria, cumpre-se, pelo menos parcialmente, na revalorizaçáo do papel das figuras femininas ${ }^{127}$. Assim, a dificuldade que os críticos julgam centrada num desvio de género reside antes - se nos é permitido o jogo vocabular - numa transformação do género dominante no drama, que não só no título se vem a afirmar feminino. De facto, depois de um julgamento onde a sentença é proferida por uma mulher e claramente condicionada pela habilidade persuasiva de outra, é às deusas - Hera e Cípris - que o autor concede uma participação directa no destino dos soberanos de Esparta ${ }^{128}$.

${ }^{127}$ A própria escolha do Egipto como cenário da acção parece assistir a este propósito euripidiano de requalificar o papel da mulher na Atenas do séc. V a.C.. Como se refere na p. 71, n. 139, vigorava no país do Nilo um regime social de matriarcado, que atribuía às mulheres egípcias responsabilidades e funçóes bem distintas das permitidas às gregas.

${ }^{128}$ Comprovam-no, por um lado, as palavras de Teónoe, que coloca nas máos de Afrodite e de Hera a derradeira decisão quanto ao desfecho da saga dos heróis (1024-27); por outro, a súplica que Helena eleva a ambas as divindades, a fim de garantir o sucesso do seu plano (1093-1106). 
Abalando de novo preconceitos e convençóes, o trágico introduz, assim, uma séria reflexão sobre o lugar da mulher na sociedade ateniense, apresentando-a como elemento potencialmente activo na construção de uma democracia justa e igualitária. ${ }^{29}$

A ideia aprofunda-se na cena seguinte, com uma nova inversão de papéis (a quarta, mas ainda não a última, na análise que aqui apresentamos) em que alguns autores vislumbram o signo evidente da comédia: de elemento passivo na saga troiana, onde fora primeiro o prémio numa contenda de deusas e depois o troféu de uma luta sangrenta, à Espartana é agora dado protagonizar um novo confronto entre Gregos e Bárbaros, onde Menelau não só náo toma parte activa, na qualidade de libertador, como se converte em objecto de uma operação de resgate engendrada (1049-1089) e liderada por Helena. Quanto a nós, porém, as grotescas soluçóes que o Atrida propóe a Helena quando por ela instado a colaborar no plano de fuga (1039-1048), náo constituem simplesmente uma via directa para o cómico fácil e imediato. $\mathrm{Na}$ verdade, sob esta imagem de inépcia, a que os teóricos somam ainda a tibieza do guerreiro ${ }^{130}$, adquire expressão viva e definitiva a crítica severa aos valores marciais, de talhe homérico, perfeitamente inoperantes e desajustados à realidade coeva ${ }^{131}$. Assim, quando Menelau acede a declarar-se morto para

${ }^{129}$ Somos, de resto, da opinião de que Aristófanes, quando transforma a assembleia feminina das Tesmofórias no palco da sua paródia da Helena, longe de pretender caricaturar um Eurípides misógino - uma visão que a crítica moderna subscreveu e ajudou a implantar - o torna antes vítima do poder de que investe a mulher nas suas tragédias (nesta, em particular), certamente tomado por excessivo à luz do contexto sócio-cultural ateniense do século $\mathrm{V}$, que remetia a mulher ao recato do gineceu, recusando-lhe uma participaçáo activa na vida da polis.

${ }^{130}$ Cf. I. Holmberg, op. cit., 35.

${ }^{131}$ Subscrevemos, neste ponto, a opinião de Segal ("The two worlds of Euripides' Helen", TAPhA 102, 1971, 605): «the male, heroic values of mainland Greece, perpetually kept before us in the theme of the Trojan war, prove ineffectual and even encumbering. Hence, Menelaus' discomfiture 
preservar a vida, evitando o confronto directo com o faraó, é o triunfo do logos sobre o ergon, ou da palavra sobre as armas, que o autor faz representar, e náo, como sugere Meltzer ${ }^{132}$, o caricato contraste entre o empolamento heróico deste que se proclamara homem de acção (814) e uma estratégia de fuga que passa, no limite, pela negação completa de si mesmo. Idêntica leitura têm os vv. 1083-86, nos quais Menelau, a conselho de Helena, se agacha junto ao túmulo de Proteu, a fim de proteger-se contra a crueldade de Teoclímeno. O quadro, todavia, não sugere apenas esta cedência do belicismo a um novo sistema de valores, mas antecipa também, no plano simbólico, a mechanê do falso funeral, que ao público não será dado presenciar. De facto, em ambas as cenas podemos ver o verdadeiro Menelau servindo-se de um sepulcro como subterfúgio para escapar à ameaça de Teoclímeno - de certa forma, uma repetição da estratégia usada na cena de Teónoe, onde o túmulo de Proteu fora argumento decisivo na persuasão da profetisa. Por outro lado, embora a situação em si pareça digna de integrar uma peça cómica, não podemos também deixar de lembrar que o motivo do herói que se esconde, que dissimula, que recorre ao disfarce ${ }^{133}$ não é de todo exclusivo

by the Portress is not just a bit of humorous stage-play, but dramatizes the alienness and inappropriateness of those martial, Trojan values which Menelaus embodies». O que o autor afirma com relação à cena da porteira julgamos ser igualmente aplicável a outros momentos dramáticos, onde se tornou comum salientar o pretenso amesquinhamento da personagem de Menelau.

132 Meltzer (op. cit., 246) assinala a incongruência que se verifica entre a afirmação inicial do herói, que recusa uma entrega passiva à morte e se predispóe ao combate activo, e a sua posterior anuência em participar de um plano no qual lhe cabe passar por morto para reconquistar a glória.

133 A. Podlecki (op. cit., 404) entende que, tal como as vestes andrajosas do herói, comummente apontadas como elemento de cómico, «the crouching position (...) so far from being intended to arouse audience's laughter is a necessary part of the camouflage». Esta leitura parece-nos também ser a mais pertinente. 
da comédia ${ }^{134}$, além de que faz pleno sentido numa peça onde o engano se apresenta muitas vezes como único caminho para a verdade. Assim, se há um desfasamento entre a linguagem épica do herói e uma actuação que atende sobretudo ao valor da eficácia, tal discordância reflecte mais uma vez a adaptação do guerreiro homérico a um mundo real onde o conceito de heroísmo se redefine em função de novos valores.

No fundo, há menos de burlesco do que de ironia - considerando a ambiguidade que assiste a um recurso táo presente na tragédia como na comédia - no retrato de Menelau e das demais personagens masculinas, que, a despeito da origem grega ou bárbara, do discurso heróico ou hostil, comungam de uma certa ingenuidade, bem diversa da inteligência exibida pelas mulheres. A própria agressividade ou violência que ostentam, o fervor bélico ou o poder absoluto que reclamam, tendem a esbater-se perante o forte ascendente feminino, que transforma em seres inofensivos e pacíficos guerreiros pujantes e déspotas cruéis ${ }^{135}$. Paradigmática desta abordagem irónica da supremacia masculina e do valor das armas é, ainda no prólogo, a intervenção de Teucro, que entra em cena desfiando contra Helena um rol de ameaças e imprecaçôes, para, instantes depois, lhe endereçar um humilde pedido de desculpas, propondo-lhe mesmo que sirva de mediadora na consulta à profetisa. $\mathrm{E}$ de pouco lhe serve o arco

${ }^{134} \mathrm{Na}$ epopeia homérica não faltam, de facto, ocasióes em que Ulisses se vale de semelhantes artifícios para fazer frente aos adversários. Quando, para transpor as muralhas de Tróia, se disfarça de mendigo (Od., 4. 244-50); ao servir-se do rebanho de Polifemo para uma fuga camuflada da gruta do Ciclope (Od., 9, 425-45); ou, na chegada a Ítaca, quando, disfarçado de mendigo, prepara a vingança dos pretendentes (Od., 20-22), Ulisses adopta, de facto, estratégias não muito distintas da aqui usada por Menelau.

${ }^{135}$ Acerca do poder que se atribui às personagens femininas, $v d$. P. Vellacott, Ironic drama. A study of Euripides' method and meaning, Cambridge, 1975, 130, 150-52. 
e a flecha quando o seu destino parece depender das palavras de duas mulheres - ironicamente, aquela a quem se refere como de todas a mais odiosa e uma outra, de origem bárbara.

Igualmente expressivo é o logro do temível faraó, cujo poder tirânico vem a ser suplantado não só pela clarividência da irmã como pela argúcia de uma mulher inerme ${ }^{136}$ que, in extremis, o converte em adjuvante do seu plano de fuga. A cena da mistificação de Teoclímeno não é, de facto, pouco referenciada quando se trata de enumerar argumentos em favor da classificaçáo da Helena como peça cómica. No entanto, a sucessão de equívocos gerados pela aparência, bem como a ambivalência das tiradas dos heróis $(1205,1225,1251,1288-92)$, dificilmente transformam a cena num momento lúdico, próximo de um qui pro quo à moda da comédia ${ }^{137}$; antes fornecem matéria relevante para a ponderaçâo do binómio palavra/realidade. De facto, quando Helena afirma estar vivo ainda o seu amor por Menelau ou quando é este que a incentiva, junto a Teoclímeno, a amar o marido ali presente prometendo reabilitar o seu nome em Esparta, as personagens duplicam o sentido e os referentes das suas frases, dando a perceber ao público o valor ambíguo da linguagem e a sua capacidade de transmitir concomitantemente o verdadeiro e o falso. ${ }^{138} \mathrm{~A}$ ironia que inevitavelmente se desprende destes versos

${ }^{136}$ Não é anódino o uso recorrente de vocábulos do campo semântico de caça para aludir ao assédio movido a Helena, táo-pouco casual o recurso à matilha e utensílios venatórios que acompanham a entrada do faraó em cena. Conferindo maior vigor à argumentação da protagonista, que surge como vítima indefesa da volúpia de um pretendente feroz e ameaçador, toda esta imagética venatória vem acentuar a fina ironia contida no desfecho da perseguição, momento em que o predador se vê enredado na armadilha da própria presa.

${ }^{137}$ A nossa posição diverge da apresentada por L. Biffi (op. cit., 94), segundo a qual o jogo de equívocos em que assenta a complexa intriga da Helena é «típico di una vera e própria commedia».

${ }^{138} \mathrm{O}$ tema da ambiguidade da linguagem, uma derivação do intenso debate alimentado entre os diversos representantes da escola sofística em 
lembra, de resto, a reacçáo de Menelau, quando, informado pela porteira da presença de Helena no palácio, considera a pluralidade de referentes de um mesmo nome (485-99). A reincidência no tópico não pode, de facto, ser ocasional ou constituir simplesmente um apontamento cómico; bem ao contrário, a conclusão a que induz contribui claramente para a definição da essência trágica da peça. De facto, não é apenas a impotência do homem valoroso face à inconstância da divindade e da fortuna que Eurípides explora nesta tragédia, mas sobretudo a impossibilidade ou incomunicabilidade de todo o conhecimento, com a angústia que inevitavelmente causa ao espectador, assim induzido a questionar as suas mais antigas e arraigadas certezas e convicçóes.

É também por esta razão que o autor não segue linearmente o paradigma do bárbaro tolo e incivilizado ${ }^{139}$ - elemento de cómico garantido -, na concepçáo da personagem de Teoclímeno. O faraó surge apenas como mais uma vítima da aparência, à semelhança de Menelau, Teucro e Helena, a dar prova da (des) ilusão em que se salda toda a certeza. Nem mesmo a irmã Teónoe,

torno da relação palavra/realidade, mereceria considerável atenção por parte de pensadores como Antifonte, que aponta a variação semântica da palavra como causa da sua incapacidade para representar o real ( $v d$. W. K. C. Guthrie, The sophists, Cambridge, 1971, 203).

${ }^{139}$ Como tivemos já oportunidade de referir no capítulo relativo à oposiçăo Gregos/Bárbaros, o tratamento da personagem de Teoclímeno não obedece rigorosamente à caracterizaçáo do bárbaro como tipo inferior, dono de uma crueldade irracional e de uma estultícia confrangedora que o torna presa fácil de trapaças e enganos. Se é indiscutível que reúne alguns traços tradicionalmente atribuídos ao bárbaro, sublinhamos, no entanto, com M. O. Pulquério (op. cit., 223) e C. Morenilla (op. cit., 198), a complexidade da personagem, que, tolerante face aos costumes dos Helenos, permitirá que seja uma diferença cultural - não a sua falta de perspicácia - a causa determinante do sucesso dos heróis. A mesma opinião tem G. Grube (op. cit., 348) que, embora defendendo a orientação cómica da peça, não reconhece a ridícula imbecilidade que muitos outros críticos atribuem ao rei egípcio, ao afirmar: «But the plot is clever: Theoclymenus is only too eager to believe the report of Menelaus death (...). How could he guess this ill-clad shipwrecked sailor to be the Spartan king?». 
encarnação da sabedoria divina, o livrará do engano a que os sentidos inevitavelmente conduzem - uma demonstração final do "nihilismo epistemológico» ${ }^{140}$, que, quanto a nós, inaugura uma nova forma de trágico na Helena.

Já com o drama a aproximar-se do desfecho, a ameaça do confronto do faraó com o servo, que em nome da justiça e com invulgar coragem se opóe ao propósito de vingança de Teoclímeno, deixa claro que a intenção do autor, ao inverter a convenção social e teatral, não é de todo a de criar situaçôes propensas ao humor. Não há, de resto, qualquer ameaça de fazer redundar o espectáculo numa grotesca cena de pancadaria, bem ao gosto de Aristófanes, com o escravo a desancar o patrão. $\mathrm{O}$ tom é bem outro e a tónica recai antes sobre a antinomia nomos/ physis. De facto, com a afirmação da nobreza de carácter do servo bárbaro, a evocar o discurso do primeiro mensageiro (728-33), demonstra Eurípides a independência da virtude face à classe, à nacionalidade ou à condição social, sugerindo a supremacia da natureza sobre a norma e a convenção. Ao mesmo tempo, o motivo que opóe servo e senhor náo deixa de evocar a problemática suscitada pelo argumento da Antígona de Sófocles, trazendo de novo a lume o dissídio entre a lei humana, representada na figura de Teoclímeno, e a lei divina, a que Teónoe, bem à semelhança da filha de Édipo, dará primazia. ${ }^{141}$

${ }^{140}$ A expressão é aplicada por Wright (apud C. Morenilla, op. cit., 193) não apenas à Helena, mas ao conjunto de obras de Eurípides que classificou como «escape-tragedies».

${ }^{141}$ Vd. A. Burnett, Catastrophe survived: Euripides' plays of mixed reversal, Oxford, 1971, 94 e 96. Apesar de bem observada, quanto a nós, esta semelhança entre o dilema de Teónoe e o de Antígona, parece-nos excessiva a afirmação de que a profetisa é a única figura séria ou "puramente trágica» do drama. Teónoe é, quanto a nós, pela gravidade da postura e do discurso, assim como pela dignidade da acção, a figura que mais se aproxima do paradigma convencional da heroína trágica. A sua intervenção no drama é, contudo, tão breve quanto discreta, ainda que 
Em síntese, enquanto se problematizam as bases desta cisão entre o universo de mulheres e homens, Gregos e Bárbaros, servos e senhores, vai progressivamente tomando forma e ganhando destaque a divergência entre os valores tradicionais, aprendidos na cartilha de Homero, e um novo sistema axiológico, que propóe uma outra forma de agir sobre o real. Relativizam-se os saberes, questionam-se convicçôes, propõe-se a mudança face a uma realidade onde tudo é instável e onde os opostos se provam comutáveis. Ora, a aparência de comicidade resulta precisamente do confronto brusco do público com esta revolução de perspectiva, totalmente inesperada. É bem provável que o espectador de uma peça trágica não estivesse preparado para ver um guerreiro ilustre recorrer a armas geralmente reservadas à mulher - as lágrimas, o apelo ao sentimento, a palavra -, da mesma forma que náo esperaria vê-la a ela tomar o comando numa situaçáo de perigo iminente. Impensável seria também, fora do âmbito da comédia, ver o servo enfrentar o senhor. E o que dizer da ideia de entregar a uma bárbara o poder de decidir, num plano divino, o destino dos heróis? Integradas estas novidades no contexto de uma obra onde a surpresa se torna regra, entendida a inversão dos modelos míticos e trágicos no âmbito de um sério compromisso com a ideologia sofística, perde vigor a tese de que o desvio à norma obedece simplesmente a uma finalidade lúdica. Assim, onde os críticos vêem cómico, vemos nós a ousadia inventiva e a modernidade de Eurípides, que abre as portas do teatro à realidade presente e concreta do espectador.

não de pouca importância, sendo em torno de Helena, a verdadeira protagonista desta tragédia, que se animam todas as grandes questóes do drama. É, de resto, no confronto entre ambas as personagens que se percebe uma clara inflexão no conceito de 'trágico', de que Eurípides é, quanto a nós, o mentor. 
Já mais elaborada nos parece ser a posição de quantos classificam a Helena como drama parodístico, mesmo se a paródia continua a náo dispensar um carregado traço de humor. Isto porque este género pressupóe um complexo processo de crítica e reapropriação de objectos literários que não é de todo alheio à concepção da peça, como ficou dito no capítulo anterior, onde analisámos com maior detalhe o modo como Eurípides procede à crítica dos modelos e convençóes trágicas e reflecte sobre a própria arte teatral. Assim, o que alguns autores entendem como imitação humorística, consideramos antes tratar-se de um exercício de reflexividade que definiríamos como metateatro. A interpretação que propomos integra-se, de resto, na própria lógica do argumento: do mesmo modo que Helena e Menelau recriam a imagem que vêem de si mesmos projectada, também a tragédia, enveredando pelo caminho da auto-análise, se justifica perante o público e se readapta ao espírito da época. Desde a concepção dos caracteres aos mecanismos trágicos mais frequentes, todo o processo de criação teatral é visado pelo autor, sempre sob uma perspectiva séria e problematizante, incompatível com o humor trocista que inevitavelmente assiste à paródia. Não faz, por isso, sentido entender como parodística a associação de Helena a Penélope ou de Menelau a Ulisses, que a tradição celebrizara como opostos morais, mesmo se os reis de Ítaca constituem evidente referencial na composição do ethos das personagens. No fundo, o discurso dramático apenas reflecte criticamente sobre o modelo de virtude masculina e feminina consagrado na poesia épico-trágica, buscando a sua conformação à realidade contemporânea. Assim, não desmerecendo a fidelidade de Penélope, a nova Helena, hábil no discurso e na arte da dissimulação, supera a rainha de Ítaca ao tomar a cargo a liderança do plano que a libertará do pretendente. À heroína não se recusa, portanto, a elevação moral exigida às personagens trágicas, antes se lhe concede 
a subjectividade ou a "posicionalidade» ${ }^{142}$ que a poesia homérica negara à mulher. Menelau, por sua vez, perde em astúcia e em perspicácia relativamente a Ulisses, mas apenas nos momentos em que se aproxima mais do Agamémnon impetuoso e aguerrido da tradição; se algum heroísmo conserva, deve-o ao corte com o ideal homérico de virtude bélica e a uma sensata cedência do orgulho másculo à prudência que as circunstâncias lhe exigem. Em suma, ambas as personagens consagram um novo paradigma de heroicidade, ao invés de promoverem a deformação jocosa ou caricatural do anterior.

Mas não é apenas ao nível da concepção dos caracteres que Eurípides tenta a remodelação do legado trágico. Evitando a mera reprodução de fórmulas e modelos desgastados, esta tragédia inaugura novos caminhos, sem, no entanto, deixar de reflectir sobre os anteriormente percorridos. A alusão, por parte de Helena, ao reconhecimento através de sinais (290-91), ou mesmo a multiplicação dos efeitos produzidos em torno deste que é um momento central da tragédia ${ }^{143}$, longe de constituir uma paródia de tradicionais cenas de anagnórise, constitui um exemplo elucidativo deste exercício de reflexividade da tragédia, que analisa e critica os seus próprios métodos, ao mesmo tempo que busca novas soluções. Daí a necessidade do autor em justificar-se quando, mercê das exigências da intriga, reincide em tópicos e esquemas já sobejamente conhecidos do seu público: passar por morto - sugere Menelau - é uma estratégia já bem antiga (1056). E é-o, de facto, se recordarmos os exemplos da Electra sofocliana ou das Coéforas, de Ésquilo, em que ao sucesso do plano de vingança do filho de Agamémnon assiste sobretudo

${ }^{142} \mathrm{O}$ conceito é explanado por I. Holmberg, op. cit., 21 sqq..

${ }^{143}$ Cf. A. Burnett (op. cit., 1971: 93): «In Menelaus, the usual effects of recognition have been exaggerated because the poet is for the moment using his bizarre fiction to show what a recognition scene can do for a play". 
a falsa notícia da sua morte. Na boca do Atrida, coloca, pois, o autor a previsível censura da crítica, preparando a defesa antecipada ${ }^{144}$. Assim, as sugestóes antes propostas pelo herói e recusadas pela consorte, por inviáveis e despropositadas, acabam sublinhando o brilhantismo da estratégia de Helena, que coincide, afinal, com o expediente encontrado pelo tragediógrafo para solucionar o impasse dos heróis. Ao desdobrar perante o público um conjunto de possíveis desenvolvimentos da intriga, o autor não só reflecte sobre o processo de construção do argumento como logra legitimar, no próprio discurso teatral, as soluçôes dramáticas exploradas ${ }^{145}$.

Que Eurípides age criticamente sobre a tradição e explora novos caminhos para a tragédia parece ser inferência segura nesta discussão sobre o género da Helena e um ponto de consenso entre os seus intervenientes. Não pretendemos, com isto, afirmar que o registo da peça se aproxima da austeridade e grandiloquência que caracteriza a tragédia esquiliana, mas antes que o tom ligeiro do discurso dramático, longe de assinalar um desvio genológico ou um movimento de degeneração da tragédia ${ }^{146}$, permite um diálogo mais próximo entre o discurso teatral e o público a que se dirige.

${ }^{144}$ Esta é a opiniẫo de G. Bond ("Euripide's parody of Aeschylus", Hermathena 118, 1974, 11-12), que admite que, numa época marcada pela crescente competitividade entre dramaturgos (situação que Aristófanes recria n' As Rãs com grande humor), as intrigas não só caminhariam para uma cada vez maior complexidade como estariam permanentemente sujeitas a duras críticas por parte dos poetas rivais. Nesta linha, G. Grube (op. cit., 346) interpreta a passagem como referência parodística a uma técnica bastante usada por outros dramaturgos contemporâneos.

${ }^{145}$ C. Morenilla (op cit. 189) identifica nesta cena um caso nítido de metateatro em que as personagens expóem ante o público os artifícios do autor, desvelando, por meio da recriaçáo de um motivo convencional, a ficcionalidade da tragédia.

146 Discordamos, neste ponto, de P. Masqueray (Théories des formes lyriques de la Tragédie Grecque, Paris, 1895, 212, apud M. Dirat, op. cit., 1976: 292-93), que considera a Helena, pelo tom de banalidade que a atravessa, uma peça de «decadência». 
A ideia de que a tragédia merece um atributo que dê conta do seu carácter inovador, já de resto considerada por Aristófanes quando se the refere como kaine Helene $e^{147}$, afigura-se-nos, assim, não só admissível como lógica. As propostas mais frequentes são, todavia, pouco satisfatórias por concederem excessivo realce a elementos que nesta peça não são essenciais mas acessórios. Classificar a Helena como tragédia romanesca pode, efectivamente, fazer todo sentido, se considerarmos que o argumento náo só reúne os principais ingredientes do romance como obedece a um intrincado esquema de avanços e recuos, venturas e desventuras, esperanças e obstáculos, que se resolve, enfim, num não inesperado mas ainda assim fulgurante happy $\mathrm{end}^{148}$. Os próprios protagonistas cabem com natural facilidade no molde dos heróis romanescos, apenas com as diferenças ${ }^{149}$ que naturalmente lhes impôe a tradição mitológica: nem Menelau é um jovem arrebatado e imaturo, afeito a arroubos amorosos, nem a Espartana donzela inerme e passiva à maneira de uma Calírroe ${ }^{150}$. Ainda

${ }^{147}$ Cf. Ar., Th., 850.

${ }^{148}$ A semelhança deste argumento com o padrão do romance grego náo pode ser mais evidente, a considerar o conjunto de tópoi elencados por M. F. Pinheiro ("Origens gregas do género", F. Oliveira et alii (coord.), $O$ romance antigo: origens de um género literário, Coimbra, 2005, 22) como definidores do género: «uma intriga complicada, que se desentranha em aventuras de toda a espécie (viagens, tempestades, raptos, naufrágios), tentativas de suicídio, mortes aparentes e divindades adversas (...) que, no fim, encaminham a acção para um final feliz.».

${ }^{149}$ C. Morenilla (op. cit., 190) apresenta desenvolvidamente os aspectos em que o argumento e personagens da Helena se desviam do padrão do romance grego.

${ }^{150}$ N. Marini (op. cit., passim) analisa com detalhe a relação intertextual que se estabelece entre a Helena euripidiana e o romance de Cáriton, Quéreas e Calírroe. De acordo com a autora, a influência do teatro de Eurípides torna-se visível nesta obra, antes de mais, ao nível da concepção das personagens, mediante a identificação entre Helena e Calírroe - ambas donas de uma beleza tão extraordinária quanto funesta -, Menelau e Quéreas - no papel dos heróis libertadores -, e Dionísio e Teoclímeno - os antagonistas que compóem o triângulo amoroso. A intertextualidade está 
assim, incomparavelmente bela e virtuosa, capaz de despertar paixôes infrenes e invejas desmedidas, Helena parece talhada para o percurso atribulado a que nenhuma heroína romanesca pode escapar: raptada pelos deuses e afastada, contra a vontade, do seu par amoroso, vamos encontrá-la num território de beleza exótica, que é só por si promissor de empolgantes aventuras. Para adensar a emoção, não falta o assédio de um poderoso pretendente à esposa desvalida que, dona de uma fidelidade a toda a prova, aguarda firmemente o dia em que virá resgatá-la o bem-amado Menelau. Depois de reconhecimentos falhados (541-42, 567), arroubos de um exaltado lirismo amoroso (622-57), juras de fidelidade $(795,799)$ e de morte $(835-42)$, a que náo faltam breves acessos de desconfiança ou ciúme $(794,834)$; depois de uma morte ardilosamente forjada e de convertidos os oponentes em adjuvantes, os protagonistas, de novo unidos, embarcam rumo à pátria e à felicidade interrompida. Nada parece, enfim, faltar à intriga que possa desmentir-lhe um parentesco directo com a narrativa romântica que em séculos posteriores viria a conquistar um lugar importante no panorama literário grego.

Uma observação mais atenta deixa, contudo, perceber que o amor não é, ao arrepio do que supóe toda a novela romântica, o eixo central da acção dramática, tão-pouco a força que anima os heróis nesta senda de aventuras ${ }^{151}$. De resto, em Helena, parece ser mais evidente o respeito pela instituição matrimonial, como sugere C. Morenilla ${ }^{152}$, do que o impulso da paixão. Reabilitar o bom nome - o que, na peça, significa provar a descontinuidade

ainda patente no aproveitamento de motivos e temas desenvolvidos na peça: a notícia da falsa morte do herói, seguida das honras fúnebres, é apenas um exemplo entre muitos outros que a autora enumera.

151 Excessivas nos parecem leituras como as de M. Dirat (op. cit., 14-15) que entende que é movido pelo amor de Helena e por amor a esta que Menelau restabelece o ânimo enfraquecido pelas adversidades.

152 Op. cit., 191, 196. 
entre aparência e essência - é o objectivo que une, afinal, os heróis, motivando toda a sua actuação. Os obstáculos que, entretanto, se interpóem no caminho do casal, a adiar primeiro o reconhecimento e depois o regresso à pátria, não constituem, portanto, meros expedientes usados no retardamento da acção e no adensar de expectativas; ilustrando as ciladas que os sentidos colocam ao conhecimento da verdade, as sucessivas dificuldades encontradas pelos heróis são sobretudo pensadas em função do debate epistemológico que o argumento promove. Do mesmo modo, a excepcional beleza da protagonista não serve apenas o paradigma da heroína romântica, tal como a infeliz circunstância do naufrágio de Menelau não constitui simplesmente mais uma vicissitude na intrincada teia de acçóes em que se cruza o destino dos esposos. $\mathrm{O}$ mesmo se pode afirmar a respeito da colaboração de Teónoe no plano de fuga dos reis de Esparta, ou da ameaça representada pelo temível soberano egípcio ao seu projecto de salvação. De resto, até o acesso de ciúme do Atrida, que se resolve num pacto de morte com laivos de sentimentalismo ultra-romântico, não revela senão a preocupação extrema dos heróis com a honra e a reputação. Reflectindo sobre a beleza e a glória como bens ilusórios, ou propondo a discussão em torno das antíteses morte/vida e grego/bárbaro, que foram já objecto de análise neste trabalho, a tumultuada saga de Helena e Menelau vem sobretudo dar forma teatral às teorias fundamentais da Sofística, provando que é sobre o debate de ideias que se constrói a intriga romanesca e não o inverso.

Em suma, a despeito da coerência da argumentação que a fundamenta, esta proposta de classificação da Helena como drama romanesco peca por colocar num plano secundário aquele que é o eixo central do argumento: o debate intelectual. Mesmo ocupando um lugar que a tragédia tradicionalmente reservara à emotividade, a forte componente filosófica da peça não desvirtua, 
no entanto, a essência do género. Inútil será, por certo, buscar na Helena o paroxismo das emoções ou a manifestação extremada do pathos que encontramos numa Medeia ou num Hipólito, com o simples objectivo de legitimar a classificação de tragédia que para ela reclamamos. Nem mesmo a cena do massacre final lhe confere este vigoroso dramatismo que a todo o custo procuramos encontrar na peça. Não deixa de ser verdade que o vívido relato do mensageiro evoca o sangrento confronto entre Gregos e Troianos e que o quadro mítico da destruição de Ílion, pela amplitude que adquiriu como símbolo da luta entre Gregos e Bárbaros, não passa ao largo da sensibilidade do público ateniense, para mais fragilizado por um desastre recente fora das fronteiras da Hélade. Somos, contudo, da opinião de que esta sequência dramática, inúmeras vezes apontada como contraditória da mensagem pacifista de que Eurípides se faz porta-voz, além de não ferir o princípio anti-bélico preconizado pelo autor, também não dá espaço a que a emoção se sobreponha à ideia, força motriz do drama. Inevitável seria, desde logo, a hesitação do público quanto à posição a tomar: de um lado, Helena e Menelau, que depois de anos de tormento, entrevêem enfim a possibilidade de reverter as injustiças a que o capricho da divindade os condenara e de recobrar o bom nome desonrado; de outro, os marinheiros bárbaros, prova viva da hospitalidade egípcia, que, mesmo alheios a toda a desgraça que assolara os heróis, acabam sendo impiedosamente chacinados pelo exército grego, sob o comando de Menelau e o incitamento de Helena. Depois de ter acompanhado o trajecto dos protagonistas, de ter desejado entre ansiedade e expectativas, receios e esperanças, o sucesso do seu plano de fuga, seria natural, como afirma L. A. Post, que o público se regozijasse com o triunfo dos heróis; apenas não podemos concordar com o autor quando afirma que o terrível massacre da tripulação egípcia se dilui nesta celebração da vitória 
do casal espartano. ${ }^{153}$ Uma tal leitura mina, de resto, o propósito último do tragediógrafo que com esta reposiçăo da guerra de Tróia pretende sobretudo nivelar os dois pólos da contenda, relativizando o significado dos termos 'vencidos' e 'vencedores', 'heróis' e 'viláos', num evidente esvaziamento do sentido da guerra. A divisão, o debate, a contradição transferem-se agora do plano exterior do drama para a mente do espectador. De facto, se em outras peças, a adesão solidária ao destino dos heróis trágicos não é problemática, o mesmo não se verifica em relação à Helena, onde não ocorre sem reservas. De qualquer modo, não devemos deixar de notar a saída irónica a que conduz esta solidarização do espectador com ambas as partes em conflito: ao alegrar-se com o regresso de Helena e Menelau à pátria, o público ateniense estaria a colocar-se do lado dos Espartanos, inimigos de longa data; concomitantemente, a piedade que sente pelo destino dos Egípcios dissipa de certa forma uma hostilidade secular alimentada contra o mundo não helénico. Neste equilíbrio de emoçóes, em que a exultante glória dos heróis, reconciliados com a tradição, contrabalança com o terror de um verdadeiro massacre, próximo da realidade vivenciada pelos Gregos em 413 a. C., pressente-se, assim, a força apaziguadora da arte ${ }^{154}$ : sem poder para anular as desgraças presentes e reais, a tragédia, convertida no tribunal em que se discutem e dirimem conflitos antigos, apresenta-se como espaço de expurgação das dores e dos fracassos recentes e, finalmente, como eficaz veículo de evasão. Assim, o regresso de Helena à pátria, com o feliz desfecho que aos Dioscuros cabe relatar, metaforiza a promessa de um futuro ameno e harmonioso

${ }^{153}$ Cf. L. A. Post, op. cit., 117: «Since those slaughtered in the Helen are anonymous and unknown, it seems unlikely that an audience would feel even minimal pity and terror for them. They would be too busy rejoicing over the escape of the Greeks».

${ }^{154} \mathrm{O}$ tópico é já sugerido no segundo estásimo da peça, como pode ler-se nas pp. 90-91. 
para a Hélade. De resto, se conciliarmos o gosto de Eurípides pelos jogos vocabulares com o paralelo que nitidamente estabelece entre o sofrimento de Helena e o das anónimas esposas, mães e irmâs helénicas, grandes vítimas de um drama tradicionalmente representado no masculino, perceberemos que o feliz desenlace da protagonista traduz a concretização do sonho da Grécia real, que anseia menos por glórias militares e feitos memoráveis do que pela reposição da ordem familiar, quebrada à custa de inúteis conflitos. Em última análise, celebra-se na peça um novo ideal de vida, onde ressoa o conhecido gosto euripidiano pela representação dos oikeia pragmata. No fundo, destitui-se o heroísmo sonante das glórias colectivas em favor da valorização de uma felicidade colectiva, mas vivida à escala individual.

No entanto, apesar de favorável aos heróis - e também a um público que neles projecta a esperança de um melhor porvir -, não deixa de ser trágico o desenlace da Helena, por paradoxal que se nos afigure a conclusão. Ousamos até afirmar que este desfecho pode dar um precioso contributo para o entendimento do conceito clássico de 'tragédia', geralmente contaminado por consideraçôes anacrónicas, emitidas à luz dos moldes de análise contemporâneos. Verdadeiramente trágico - demonstra-nos a Helena - é o discurso capaz de (co)mover um público que nele encontra a expressão mais próxima dos seus dilemas e angústias. E a peça de Eurípides é, até ao último verso, a voz do espectador coevo, que, já bem distante da época heróica, problematiza a própria existência, coloca em causa as certezas e o conhecimento, considera o poder da palavra no destino da sociedade e da polis, pondera o sentido do nomos face à universalidade das leis cósmicas, questiona o sentido da guerra e avalia a sua relaçáo com os outros povos, discute, enfim, o contributo da poesia (ou da tragédia, em particular) na representação desta nova realidade. No permanente e inconcluso debate de ideias - as grandes ideias 
que agitavam a sociedade ateniense de então - reside, pois, a essência trágica da Helena. Daí que a retórica domine a estrutura e o argumento, assim como a linguagem e o estilo da peça. De facto, mesmo não sendo a defesa de Helena o objectivo central de Eurípides ${ }^{155}$, o nome da personagem converte-se desde os primeiros versos em símbolo da ideia feita, da certeza, do axioma, que convém refutar, desacreditar, desmontar. Por outro lado, se em nenhum momento assistimos a um verdadeiro agôn entre as personagens ${ }^{156}$, nem por isso podemos esquecer que é no plano individual que os heróis gerem os maiores conflitos: a inocência que luta por opor-se à culpa ou a essência que se esforça por prevalecer sobre a imagem são apenas exemplos de entre muitos que tivemos já oportunidade de analisar com maior ou menor profundidade ao longo da nossa introdução. Em suma, a marca da retórica não se torna visível apenas em alguns momentos específicos do drama, ainda que em muitas cenas o discurso das personagens fique bem próximo - pelo propósito, pelos recursos técnico-expositivos, muitas vezes até pelas emoçóes que concita e manipula - do cultivado nas assembleias e tribunais atenienses. A rhesis de Helena e Menelau perante Teónoe é talvez o exemplo

${ }^{155}$ Embora não possamos deixar de concordar com F. Jouan ("Euripide et la rhétorique", $\operatorname{LEC} 52,1984,5)$ quando afirma que «la pièce d'Hélène tout entière est un epainos de l'heroïne si souvent maltraitée dans les œuvres antérieures», temos, no entanto, algumas reservas em identificá-la, como faz o autor, com os «éloges rhétoriques» de Górgias e Isócrates, precisamente por considerarmos que, apesar das evidentes semelhanças com este tipo de exercício antilógico, o objectivo último de Eurípides não é o de ilibar a heroína das culpas que a tradição lhe imputara.

156 Não é esta opinião de D. J. Conacher ("Rhetoric and relevance in euripidean drama”, $A J P h$ 102, 1981, 18-19), que, referindo-se à cena da persuasão de Teónoe, entende as diferenças nos pleitos de Helena e Menelau como duas posiçóes adversas em conflito, porque fruto de duas personalidades distintas em contraste. Desta forma responde o autor a J. Duchemin, que, por sua vez, nota o carácter não convencional deste agôn, ao assinalar o perfeito acordo que se verifica entre Helena e Menelau na defesa da mesma causa. 
mais flagrante e imediato, mas a este podemos juntar ainda alguns outros: o monólogo inicial dos protagonistas, evidente réplica à versão tradicional do mito, que condena ambos os heróis; a hábil condução, por parte de Helena, do seu diálogo com Teucro; os momentos em que os heróis discutem as possibilidades viáveis para a fuga $(810-33,1035-62)$, num discurso de tipo deliberativo ${ }^{157}$; a persuasão de Teoclímeno, que prova o parentesco - já reconhecido na época - entre retórica e teatro; e até o confronto entre o faraó e o segundo mensageiro, que contrapóe à falácia da autoridade o argumento da justiça. Sobre o lugar e as marcas da retórica neste texto de Eurípides, o muito que poderia ainda acrescentar-se extrapola os objectivos desta consideração final sobre o género da peça. Limitamo-nos, assim, a assinalar o seu peso num discurso onde, como vimos, são as ideias em permanente confronto que impulsionam a acção. De facto, mesmo sob a aparência de uma harmonia restaurada, a ambiguidade, a dúvida e o debate parecem subsistir. Depois de exaltar a virtude de Helena, protagonista de um drama vivido no feminino, o príncipe egípcio acaba subtilmente por semear a desconfiança sobre a virtude da mulher (1687), não só a reacender a polémica em torno da posição feminista ou anti-feminista de Eurípides ${ }^{158}$, mas sobretudo a relembrar a natureza paradoxal de toda a realidade ou o sentido duplo de cada discurso. O próprio coro, num remate que, pela sua clara convencionalidade (1688-92) $)^{159}$, parece cortar com a linha inovadora da peça,

${ }^{157}$ Um dos três géneros aristotélicos do discurso partidário (cf. H. Lausberg, Elementos de retórica literária. Tradução, prefácio e aditamentos de R. M. Rosado Fernandes, Lisboa, $\left.{ }^{5} 2004,83-84\right)$.

${ }^{158} \mathrm{O}$ tema será, de resto, o móbil do argumento de Th., a peça em que Aristófanes, como antes se disse, parodia o estilo do autor e as novidades por ele experimentadas na Helena.

${ }^{159} \mathrm{Os}$ vv. pronunciados no êxodo repetem-se, com ligeiras cambiantes, em Alceste, Medeia, Andrómaca, Bacantes. 
consegue, mesmo assim, reforçar um incómodo sentimento de incerteza face a uma verdade multímoda e inapreensível, que escapa irremediavelmente ao entendimento do homem.

Que poderá haver de mais trágico do que a realidade? E o que é mais sério e elevado do que a discussão da essência do próprio homem, a que emprestam voz as personagens da Helena? Explicar o verdadeiro significado das palavras de Aristóteles quando se refere a Eurípides como o mais trágico dos poetas ${ }^{160}$ converte-se em tarefa bem menos complexa depois de compreendido o sentido profundo de uma peça onde fica claro que a tragicidade não depende de finais desditosos ${ }^{161}$, do aparato de destruição que acompanha a catástrofe ou sequer da intensidade do pathos dos heróis. Refuta-se, assim, a tese de Pohlenz de que, na Helena, se revela a tendência euripidiana para «a íntima profanação da tragédia» ${ }^{162}$. É bem o inverso que se verifica com esta intelectualização do drama, que, ao mover-se do campo dos sentimentos para o da consciência, permite a perpetuação do sentido trágico para lá do momento do espectáculo.

Leva-nos, enfim, a nossa análise a propor para a peça uma leitura diversa daquela que aconselha a posição dominante dos críticos. Reformulando a expressão de A. Burnett, quando apoda a Helena de "comédia de ideias»" ${ }^{163}$, não hesitamos, por isso, em classificar esta peça como Tragédia de Ideias.

${ }^{160}$ Cf. Arist., Po., 53a.

${ }^{161}$ Daí que os finais felizes, tão do gosto euripidiano, embora referidos na Poética (53a) como menos adequados à tragédia, não comprometam o juízo do Estagirita acerca do tragediógrafo (vd. supra n. 222).

${ }^{162}$ Apud M. O. Pulquério (op. cit., 209).

163 Este é de resto o título que dedica a um dos seus artigos sobre a peça: "Euripide's Helen: a comedy of ideas" (cf. n. 107). 
(Página deixada propositadamente em branco) 
Helena 
(Página deixada propositadamente em branco) 


\section{Argumento de Helena}

Na história que conta acerca de Helena, diz Heródoto ${ }^{1}$ que ela esteve no Egipto, o que Homero confirma na Odisseia ${ }^{2}$, ao fazê-la oferecer a Telémaco o mesmo filtro que lhe dera Polidamna, esposa de Tóon, para esquecer as penas. Não é exactamente esta a versão de Eurípides. No dizer de Heródoto ${ }^{3}$ e Homero, durante as suas errâncias com Menelau, após a destruição de Tróia, Helena veio dar ao Egipto e aí conseguiu os ditos filtros. Eurípides, por sua vez, afirma que em Tróia nunca esteve a verdadeira Helena, mas, em seu lugar, um fantasma - isto porque Hermes, depois de a ter raptado, por ordem de Hera, confiou a sua guarda a Proteu, rei do Egipto. Após a morte deste, o filho, Teoclímeno, tentou à força desposá-la e foi aí que ela tomou assento, como suplicante, junto ao túmulo de Proteu. É então que se depara com Menelau, que, mesmo tendo perdido no mar as suas naus, mantinha ainda a salvo, no interior de uma gruta, alguns companheiros. Depois de entrarem em diálogo e de maquinarem um estratagema, conseguem ludibriar Teoclímeno, embarcando num navio a pretexto de celebrarem um sacrifício em honra de Menelau, que morrera no mar. E assim rumam a salvo em direcção à pátria.

${ }^{1}$ 2. 113-19. Vd. supra capítulo 1 do estudo introdutório.

2 4. 221-30. Vd. supra capítulo 1 do estudo introdutório.

${ }^{3}$ Ao contrário do que, por equívoco, afirma o autor deste argumento, de acordo com Heródoto, Helena jamais estivera em Tróia. Informação mais completa sobre as versóes do mito de Helena em que Eurípides terá colhido inspiração pode ler-se no capítulo primeiro do estudo introdutório. 
Personagens do DRAMa

\author{
Helena \\ Teónoe \\ Teucro \\ Teoclímeno \\ Coro de cativas gregas \\ Segundo Mensageiro \\ Menelau \\ Servo do palácio \\ Anciā \\ Dioscuros \\ Mensageiro
}


(A representar um sumptuoso palácio egípcio, a skênê emoldura o quadro de súplica em que se apresenta a protagonista: junto ao túmulo do falecido Proteu, Helena pronuncia o monólogo de abertura.)

\section{Helena}

Eis as correntes do Nilo de belas ninfas, que, em lugar das chuvas de Zeus, banha os campos e terras egípcias quando a neve branca se dissolve. Proteu ${ }^{4}$ era, em vida, o rei desta terra. [Na ilha de Faros ${ }^{5}$ tinha a sua morada, mas era senhor de todo o Egipto.] (5) Por esposa tomou uma de entre as virgens marinhas, Psâmate ${ }^{6}$, depois de esta ter deixado o leito de Éaco ${ }^{7}$. A este palácio deu dois filhos: um rapaz, Teoclímeno - assim chamado [porque o pai venerara os deuses ao longo da vida ${ }^{8}$-], (10) e uma nobre virgem, orgulho de sua mãe, a quem chamavam Eidồ enquanto

${ }^{4}$ A respeito da figura de Proteu em Homero, Heródoto e Eurípides, $v d$ supra p.

${ }^{5}$ Nome do piloto que, finda a guerra de Tróia, conduzia em direcçáo a Esparta a nau onde viajavam Helena e Menelau. Na sequência de uma tempestade que os desviou para o Egipto, morreu vítima de mordedura de cobra numa ilha próxima de Alexandria, que recebeu o seu nome (cf. J. Brandão, Dicionário Mítico-etimológico da Mitologia Grega, Petrópolis, vol. I, ${ }^{2} 1993$, 431). Nesta ilha ficaram retidos Menelau e os demais tripulantes da nau durante vinte dias, mercê de uma calmaria, até que Proteu, divindade marinha, aconselhou Menelau a regressar ao Egipto para aí oferecer sacrifícios aos deuses (cf. P. Grimal, op. cit., 305) e poder assim retomar a viagem rumo a Esparta. Possivelmente, a alusão à ilha onde habitava Proteu tem por objectivo evocar a variante do mito troiano que explica a relação entre a figura de Helena e o país onde decorre a acção desta peça.

${ }^{6}$ Vítima da perseguição amorosa de Éaco, de quem tentou em vão escapar, metamorfoseando-se em foca, a Nereide gerou Foco, que acabou sendo morto pelos meios-irmáos. Como refere o texto euripidiano, abandonou mais tarde Éaco para casar-se com Proteu, rei do Egipto.

${ }^{7}$ Filho de Zeus e da ninfa Egina (cf. Hes., Th. 1003-1005).

${ }^{8}$ Acerca do significado dos nomes dos príncipes egípcios e sua relaçáo com o papel que cumprem no drama, vd. supra p.

${ }^{9}$ Alguns autores relacionam o nome de infância da profetisa com o 
criança. Já na flor da juventude, chegada à idade de casar, foi-lhe dado o nome de Teónoe, porque conhecia todas as coisas divinas - as presentes e as futuras ${ }^{10}-$, dom que herdara de seu avô Nereu ${ }^{11}$. (15)

Quanto a mim, tenho por pátria a célebre Esparta e é Tíndaro o meu pai. Conta-se, porém, que Zeus, sob a forma alada de um cisne, voou sobre a minha mãe, Leda, e, fingindo escapar à perseguição de uma águia, logrou unir-se a ela com este embuste (20) - se é que a história é verdadeira... ${ }^{12}$

Sou conhecida por Helena e os males que sofri vou agora contar-vos. Certo dia, três deusas - Hera, Cípris e a virgem filha de Zeus (25) - foram ao encontro de Alexandre no recôndito vale do Ida. O motivo era a beleza: queriam que, como juiz, determinasse qual delas era a mais formosa. Ora, Cípris, que me prometera a Páris em casamento, aliciando-o com a minha beleza - se pode chamar-se belo ao que traz infortúnio -, foi a deusa vencedora. Então, Páris, deixando os redis do Ida, partiu para Esparta na intenção de reclamar o meu leito. (30) Hera, porém, despeitada por não ter vencido as rivais, envolveu num vento de fantasia as minhas núpcias com Páris, entregando ao

nome da divindade marinha Idótea, que teria aconselhado Menelau a consultar seu pai, Proteu, sobre a forma de como poderia seguir viagem quando aquele ficou retido na Ilha de Faros (vd. supra p. 10).

${ }^{10}$ A clarividência de Teónoe prefigura a omnisciência de Cassandra, tal como a virtude de Proteu evocará a sabedoria de Príamo e a volúpia de Teoclímeno a paixão infrene de Páris. Sobre a relação intertextual entre as categorias dramáticas da peça e as personagens/quadros do ciclo troiano, $v d$. cap. 1 do Estudo Introdutório.

${ }^{11}$ Divindade marinha, filho de Ponto e Geia, que, com Dóris, gerou as Nereides. O dom profético de Nereu é documentado em Hes., Th. 233-36.

${ }^{12} \mathrm{O}$ cepticismo de Helena introduz uma reflexão de teor metamitológico (cf. C. Morenilla, op. cit., 185), que se salda na sugestáo da ficcionalidade da própria personagem e da acção a que dá corpo. $\mathrm{O}$ comentário não é, pois, despiciendo na discussão do tema palavra/verdade que terá lugar no decurso da peça. 
filho do rei Príamo, em meu lugar, uma imagem viva, esculpida à minha semelhança na matéria de que é feito o céu. E está iludido de que me possui (35) - vã ilusão! - mesmo sem me possuir. A estes males, sobreveio o desígnio de Zeus, que levou a guerra ao país dos Helenos e aos desventurados Frígios, para assim aliviar a Terra-Mãe, sobrepovoada, (40) e tornar célebre o mais valoroso herói da Hélade ${ }^{13}$. Na verdade, não fui eu a causa da guerra de Tróia ou o prémio da lança helénica, mas o meu nome. Hermes levara-me envolta numa nuvem através dos vales celestes - prova de que Zeus me não esquecera - (45) e deixou-me no palácio de Proteu, eleito por ser de entre os mortais o mais virtuoso, a fim de que o meu leito se conservasse imaculado para Menelau. $\mathrm{E}$ aqui estou eu, enquanto o meu desditoso esposo, depois de reunir um exército, rumou às muralhas de Tróia no encalço dos meus raptores. (50) Por minha causa, muitas vidas se perderam nas margens do Escamandro ${ }^{14}$. E eu, que tudo isso sofri, sou agora amaldiçoada e todos acreditam que, por haver traído o meu esposo, desencadeei uma guerra terrível para os Helenos. (55)

Por que razão vivo eu ainda? Do deus Hermes ouvi a profecia de que voltaria um dia a viver na célebre planície de Esparta com o meu marido, convicto aquele de que não fui para Ílion, nem partilhei o leito de nenhum homem. A verdade é que, enquanto Proteu viu a luz do sol, (60) o meu casamento não sofreu ameaça. Porém, desde que no seio obscuro da terra foi sepultado, o filho do falecido rei tem-me perseguido, na intenção de fazer-me

${ }^{13}$ Helena refere-se, neste passo, a Aquiles.

${ }^{14}$ Rio que banha Tróia. E conhecido o célebre episódio homérico (Il. 21. 214 sqq.) em que o Escamandro, personificado, se enfurece contra Aquiles pela imensidão de corpos troianos lançados no seu leito e persegue impetuosamente o herói, inundando as margens com as suas correntes de sangue e depositando sobre os campos os cadáveres dos soldados tombados em combate. 
sua mulher. E eu, sempre fiel ao meu esposo de outrora, vim prostrar-me diante do túmulo de Proteu como suplicante, para que preserve intacto o meu leito para Menelau: (65) já que corre na Hélade a má fama do meu nome, ao menos não seja o meu corpo votado à desonra nesta terra.

(Teucro entra em cena, empunhando o seu arco.)

\section{Teucro}

Quem é o senhor deste palácio imponente? Bem merece ser comparado à morada de Pluto $^{15}$, tão majestosos são os seus pórticos e bem ameados os domínios. (70) Céus! Que espectáculo é este a que os meus olhos assistem?! Vejo a imagem sanguinária da mais odiosa das mulheres, aquela que me perdeu a mim e a todos os Aqueus! Que os deuses te esconjurem, por seres de Helena a cópia tão perfeita! Não estivesse eu a pisar solo estrangeiro (75) e morrerias vítima deste dardo infalível, como paga da tua semelhança com a filha de Zeus.

\section{Helena}

Porquê, infeliz? Diz-me, quem quer sejas: porque te afastaste de mim com repulsa e me odeias pela malfadada sorte dessa mulher?

\section{Teucro}

Foi erro meu. Cedi à ira mais do que devia. (80) É que toda a Hélade odeia a filha de Zeus... Perdoa-me o que disse, senhora.

\section{Helena}

Quem és tu? De que terra vens até estas paragens?

\section{Teucro}

Sou um desses desventurados Aqueus, senhora.

${ }^{15}$ Filho de Deméter e Iáson, Pluto, a Riqueza, surge no cortejo da deusa representado sob a forma de um menino que transporta a cornucópia da abundância (cf. P. Grimal, op. cit., 380). 


\section{Helena}

Não admira, então, que odeies Helena... (85) [Mas quem és e donde vens? De quem és tu filho?

\section{Teucro}

O meu nome é Teucro, Télamon o pai a quem devo a vida e Salamina a pátria que me viu crescer.

Helena

E o que te trouxe aqui às terras do Nilo?]

Teucro

Fui expulso da terra natal como proscrito. (90)

Helena

Infeliz de ti! Mas quem te baniu da pátria?

Teucro

Télamon, meu pai. Poderia haver parente mais próximo?

Helena

E por que razão? Por detrás desse caso, há de certo alguma calamidade...

\section{Teucro}

Foi a morte de meu irmão Ájax, em Tróia, a causa da minha ruína.

\section{Helena}

Como? Não terá sido a tua espada que lhe tirou a vida? (95)

\section{Teucro}

Foi ele quem se matou, precipitando-se sobre a própria espada.

\section{Helena}

Num acesso de loucura? Afinal, quem no seu perfeito juízo ousaria fazê-lo?

Teucro

Conheces um tal de Aquiles, filho de Peleu? 


\section{Helena}

Sim. Foi em tempos pretendente de Helena, segundo ouvi dizer. ${ }^{16}$

\section{Teucro}

Pois a morte dele originou entre os pares uma disputa pelas suas armas. (100)

\section{Helena}

Mas, afinal, o que há de tão terrível para Ájax nesta história?

\section{TEUCRO}

Ao ver que fora outro a conseguir as armas, pôs termo à vida. ${ }^{17}$

${ }^{16}$ Segundo C. Morenilla (op. cit., 185-86), a afirmação de Helena não possui qualquer fundamento mitológico, parecendo tratar-se de uma invenção de Eurípides. Esta ideia encontra confirmação num fragmento de Hesíodo que refere a impossibilidade de o herói ter competido com os restantes pretendentes à mão de Helena, dada a sua tenra idade (fr. 204. 88-92 M-W). O regresso insistente a versōes menos comuns ou de todo desconhecidas do mito conduz, segundo a autora - que neste ponto subscreve a opinião de Wright -, a uma reflexão sobre o seu carácter ficcional, que designa de metamitologia. Dale (Euripides. Helen, Oxford, 1967, 73), por sua vez, explica a inovação com base numa necessidade de verosimilhança: com esta referência a Aquiles, pretenderia o trágico justificar o facto de Helena conhecer o herói, mesmo não tendo assistido à guerra que o celebrizara.

${ }^{17}$ De acordo com a versão do mito celebrizada na tragédia homónima de Sófocles, Ájax, enlouquecido por terem sido atribuídas a Ulisses as armas do falecido Aquiles, de que considerava ser o mais digno legatário, dizimou os rebanhos destinados a alimentar os soldados gregos, acreditando tratar-se do próprio exército aqueu. $\mathrm{Na}$ manhá seguinte, quando percebeu ter sido tomado por uma alucinação, incapaz de suportar o vexame, pôs termo à própria vida. A referência à personagem de Ájax náo representa, quanto a nós, um excurso inócuo por episódios paralelos à linha central do drama. Afinal, as circunstâncias da sua morte em pouco diferem das dos demais guerreiros mortos em Tróia, segundo a versáo apresentada por Helena. Assim, da mesma forma que o filho de Télamon, desejoso de ver coroados de glória os seus feitos militares, cai em desgraça devido a um engano da visão, também os guerreiros helénicos, ávidos de fama e toldados por uma enganadora ilusão - o eidolon de Helena -, acabam sendo os causadores da sua própria ruína. 


\section{HeLena}

E tu sofres agora à conta da sua desgraça?

Teucro

Sim, porque náo me juntei a ele na morte.

\section{Helena}

Significa isso, estrangeiro, que estiveste na ilustre cidade de Tróia? (105)

\section{Teucro}

Depois de colaborar na sua destruição, fui eu quem caiu em ruína.

\section{Helena}

E a cidade foi já invadida pelas chamas e devastada?

\section{Teucro}

Ao ponto de não restar sequer um vestígio visível das suas muralhas.

\section{Helena}

Desgraçada Helena, por tua causa pereceram os Frígios!...

\section{Teucro}

E, com eles, os Aqueus. Grandes desgraças ocorreram, por obra sua!... (110)

\section{Helena}

E há quanto tempo foi a cidade destruída?

\section{Teucro}

Cerca de sete anos decorreram.

\section{HeLena}

E quanto tempo mais permaneceram em Tróia?

\section{Teucro}

Muitas luas: dez anos se passaram. 
Helena

E a Espartana, recuperaram-na? (115)

\section{Teucro}

Menelau levou-a de lá, arrastada pelos cabelos.

\section{Helena}

Viste tu próprio a infeliz ou falas apenas do que ouves dizer?

\section{Teucro}

Vi-a com os meus olhos precisamente como te vejo a ti - sem tirar nem pôr.

\section{Helena}

Certifica-te de que não terias tido uma miragem forjada pelos deuses...

\section{TeuCro}

Lembra-me de outro assunto, não mais daquela mulher! (120)

\section{Helena}

Acreditam, pois, que se trata de uma visão digna de confiança?

Teucro

Vi-a com os meus próprios olhos e o meu espírito vê-a ainda.

\section{HeLENA}

E Menelau, está já em casa com a esposa?

\section{TEUCRO}

Nem em Argos, nem nas margens do Eurotas ${ }^{18}$, com toda a certeza.

${ }^{18}$ Principal rio de Esparta, que deve o seu nome ao rei fundador da cidade. Nas suas margens, têm lugar dois episódios míticos referenciados no texto da Helena: o rapto da Tindárida (embora, na versáo tradicional, seja Páris e não Hermes o seu abdutor) e a união de Zeus, metamorfoseado em cisne, com Leda (cf. J. Schmidt, Dicionário de Mitologia Grega e Romana. Tradução de J. Domingos, Lisboa, 1985, 114). 


\section{Helena}

Que desgraça! Más notícias anuncias para quem esses males afectam! (125)

\section{Teucro}

É voz corrente que se encontram desaparecidos, ele e a consorte.

Helena

Mas os Argivos não faziam todos juntos a viagem?

\section{Teucro}

Faziam, mas uma tempestade dispersou-os em várias direcçôes.

\section{Helena}

Nas ondas salgadas? Por que rotas?

\section{Teucro}

Navegavam em mar aberto, a meio da travessia do Egeu.

\section{(130)}

\section{Helena}

E desde então ninguém viu Menelau chegar a terra?

TEUCRO

Ninguém. E na Grécia correm rumores de que morreu.

Helena

Estou destroçada! E a filha de Téstio ${ }^{19}$, está viva ainda?

Teucro

Referes-te a Leda? Partiu, está morta também.

\section{Helena}

Terá sido a desonrosa fama de Helena que a matou? (135)

\section{Teucro}

Ao que dizem, atou uma corda em volta do nobre pescoço ${ }^{20}$.

${ }^{19}$ Rei de Plêuron, pai de Leda e avô de Helena.

${ }^{20} \mathrm{O}$ suicídio de Leda terá sido inventado por Eurípides, o que confirma 


\section{Helena}

E os jovens filhos de Tíndaro, estão vivos ou não?

\section{Teucro}

Morreram e não morreram: há duas versōes.

\section{Helena}

Qual delas a mais credível? Oh, que penosos tormentos os meus!

\section{Teucro}

Aquela que diz que, convertidos ambos em astros, são agora deuses. (140)

\section{Helena}

Essa, sim, é uma bela notícia... Mas qual é a outra versão?

\section{Teucro}

A de que puseram termo à vida, por causa da irmã. Mas basta de histórias! Não desejo lamentar duas vezes essas desgraças. A razão que me trouxe a esta morada real foi a necessidade de ver a profetisa Teónoe. (145) Peço a tua intervenção, para que os seus oráculos conduzam os remos da minha nau, sob um vento favorável, até Chipre, terra rodeada de mar. Ditaram as profecias de Apolo que aí habitaria e que lhe daria nome de ilha - Salamina -, em memória da minha pátria. (150)

\section{HelenA}

O próprio rumo da nau te revelará o caminho, estrangeiro. Mas deixa esta terra e foge, antes que te veja o filho de Proteu, o rei que a governa. Está ausente, no momento; com os seus cães, move uma sangrenta perseguição aos animais selvagens. E - cautela! - que ele mata qualquer estrangeiro grego a que deite a mão. (155) A razão, não procures sabê-la. Nem eu ta direi.

a sua opção pelo recurso a versões menos convencionais do mito. 
Afinal, de que te serviria?

\section{Teucro}

Fico grato, senhora, pelos teus bons conselhos. Que os deuses te recompensem pela tua preciosa ajuda! Ainda que o teu aspecto seja idêntico ao de Helena, como é diferente o teu coração! (160) Que Helena tenha uma morte vil e não mais regresse às margens do Eurotas. E quanto a ti, senhora, que sejas para sempre afortunada. (Sai Teucro.)

\section{Helena}

Oh! Para abrir o longo lamento das minhas infindáveis penas, que plangentes cantos hei-de entoar? Ou que musa devo invocar (165), com lágrimas, trenos ou carpidos? Ai de mim!

(Helena entoa a primeira estrofe do párodo, enquanto o coro de cativas gregas faz a sua entrada.)

Estrofe I

Ó jovens aladas, donzelas filhas da Terra, Sereias ${ }^{21}: \dagger$ pudésseis

${ }^{21}$ Numa primeira instância, a invocação das sereias vem reforçar a íntima conexão que se estabelece entre Perséfone e a protagonista, já que alguns mitógrafos $(v d$. G . Cerri, "Dal canto citarodico al coro tragico: la Palinodia di Stesicoro, L'Elena di Euripide e le Sirene”, Dioniso 50, 1984 -1985, 421) as apresentam como companheiras da deusa, a quem haviam sido dadas asas para que auxiliassem na sua busca. Por outro lado, o passo explora a ambiguidade em que a tradição literária envolvera a imagem das sereias, sobretudo evidente no confronto das versóes de Homero e Hesíodo. Enquanto na Odisseia (12. 39-46), surgem como causadoras da destruição dos marinheiros incautos que cedem ao dolo dos seus encantos, em Hesíodo (fr. $28 \mathrm{M}$-W.), pelo contrário, foca-se o seu poder de apaziguar a fúria dos elementos. Esta representação positiva das sereias está ainda documentada na obra de outros poetas e pensadores gregos ( $v d$. G. Cerri, op. cit., 165-166) entre os quais Platão que, no mito de $\operatorname{Er}(R .617$ b-c), as representa entoando cada uma das notas que compóem a harmonia universal. A apóstrofe das sereias faz, assim, todo o sentido num momento em que a protagonista, ao mesmo tempo que expressa o pesar profundo pela morte do esposo e o desejo de se lhe seguir neste destino, busca para o luto o conforto da arte.. 
vós acorrer ao meu pranto com a flauta líbia, as siringes ou as liras e unir as vossas lágrimas aos meus tristes infortúnios, $†$ as vossas dores às minhas dores, os vossos cantos aos meus ${ }^{22}$. (170) E pudesses tu Perséfone, $\dagger$ deusa da morte $\dagger$, brindar-me com as tuas graças, acompanhando com trenos os meus lamentos, (175) para que, no teu tenebroso palácio, de mim recebesses, banhados em lágrimas, os péans aos miseráveis mortos.

\section{Coro}

\section{Antistrofe I}

Encontrava-me eu junto ao azul profundo das águas, ao longo do verde tenro da erva ondulada (180) † secando as túnicas $\dagger$ purpúreas, $\dagger$ sob o brilho dourado do sol $\dagger$, nos rebentos dos juncais, quando dali ouvi $<\ldots>$ um angustiante clamor, uma elegia não acompanhada de lira. Assim bradava, um dia, (185) entre gemidos de lamento, uma ninfa - uma Náiade ${ }^{23}$, que, $\dagger$ fugindo às núpcias através das montanhas, soltava um desesperado clamor e, sob as cavernas rochosas, denunciava, com gritos lancinantes, a união com Pá... ${ }^{24}$ (190)

${ }^{22}$ De acordo com A. Burnett (op. cit., 1971, 77-78), a invocação de divindades como forma de obter inspiração para o canto, expediente tornado comum na poesia épica e coral, reveste, no párodo de Helena, um significado particular. «By these means, he [Euripides] takes the first opportunity the tragic form will allow him to speak of art itself (...).» - sugere a autora, chamando a atençấo para o convite a uma reflexão metateatral que se vai renovando ao longo da obra. Subscrevemos ainda a opiniáo de Burnett quando afirma que o que se pretende do espectador não é uma resposta emocional ao lamento de Helena, mas a apreciação de todo o processo técnico-compositivo que está na base da construção do drama.

${ }^{23}$ Espíritos dos campos, dos bosques e das águas, as ninfas adquiriam uma designação específica consoante o elemento natural que habitavam. As Náiades são ninfas dos rios.

${ }^{24}$ Divindade bucólica oriunda da Arcádia, Pá era representado como um ser híbrido, com traços de homem e características de bode. Conotado com a sexualidade, o deus perseguia frequentemente as ninfas para satisfazer os seus desejos (cf. P. Grimal, op. cit., 345). 


\section{Helena}

Estrofe II

Ó espólio de uma nau bárbara, jovens filhas da Hélade, um marinheiro aqueu veio até aqui, veio trazer-me lágrimas e mais lágrimas!... (195) As ruínas de Tróia, consome-as um fogo devastador, por causa de mim, origem de tantas mortes ${ }^{25}$, por causa do meu nome, fonte de tantas penas; Leda encontrou a morte no laço fatal (200), sucumbindo à dor que a minha desonra lhe causou; o meu esposo, que tanto errou pelos mares, pereceu, está morto; e Castor e o irmão (205), glória gémea da pátria, desapareceram - desapareceram, abandonando os caminhos que ressoam sob o passo dos cavalos e os ginásios nas margens do Eurotas, bem orlado de juncos, onde combatem os jovens. (210)

\section{Coro}

\section{Antistrofe II}

Ai, ai! Que lote de desgraças e que destino tão deplorável o teu, mulher! Uma vida de infortúnios em sorte, em sorte te coube, quando no seio de tua mãe te gerou Zeus, fendendo o céu, refulgente, com nívea asa de cisne. (215) Que infelicidades te restam? O que não sofreste ainda na vida?... Tua mãe está morta e os gémeos, filhos bem-amados de Zeus (220), não gozaram de feliz ventura; tu não contemplas a terra pátria e, pelas cidades, corre o rumor de que a leitos bárbaros te entregaste, senhora. $\mathrm{O}$ teu esposo, esse, findou os seus dias nas ondas do mar e, por isso, jamais trarás alegria às moradas paternas ou à deusa que habita $\mathrm{o}$ templo de bronze ${ }^{26}$. (225)

$25 \mathrm{O}$ adjectivo 'polyktonos' (causadora de muitas mortes) é também atribuído a Cípris (238). A associação entre a deusa e Helena, marcada ao nível lexical, vem deliberadamente sublinhar o poder nefasto da beleza, que ambas partilham.

${ }^{26}$ Local de culto de Atena em Esparta, referenciado também nos vv. 245, 1466-67. 


\section{Helena}

Oh! Quem de entre os Frígios ou quem dos que em solo gre$\mathrm{go}^{27}$ nasceu cortou o pinho que trouxe a Ílion um mar lágrimas? (230) Com ele construiu o Priamida uma funesta nau e rumou num navio bárbaro para a minha morada, (235) [em busca da minha malfadada beleza, a fim de me tomar por esposa.] Com ele veio a pérfida Cípris, destruidora de muitos, trazendo a morte aos Dânaos e [aos filhos de Príamo]. Ó destino de infelicidade o meu! (240) No seu áureo trono, a venerável Hera, que com Zeus partilha o leito, enviou o filho de Maia, de pés velozes ${ }^{28}$. Colhia eu pétalas de rosas frescas, que guardava nas dobras da túnica29 para levar a Atena, do brônzeo templo (245), quando ele, erguendo-me nos ares, me trouxe pelo céu até esta malfadada

${ }^{27}$ F. Lourenço ("An interpolated song in Euripides? Helen 229-52", JHS 120, 2000, 133) nota o absurdo que a hipótese de um construtor grego para a nau de Páris configura, pormenor que integra o seu argumento em favor de uma interpolação dos vv. 229-52. A. M. Dale (op. cit., 82), no entanto, propóe para os vv. 229-30 um valor mais geral, próximo de 'Quem de entre todos os homens...', interpretaçáo que não nos parece falha de lógica se considerada a concepção helénica do mundo como espaço bipolar, habitado por duas raças distintas, Gregos e Bárbaros (no caso, Troianos, a ter em conta o valor metonímico que a referência assume). $\mathrm{H}$. Grégoire (op. cit., 59) aceita, no entanto, a possibilidade do valor literal destes vv., ao mencionar a existência de uma versão segundo a qual teria sido um grego e não o troiano Féreclo, como refere Homero (Il., 5. 5964), o construtor da nau em que Alexandre viajara para Esparta. Destes versos parece-nos sobretudo pertinente salientar um pormenor que náo é de todo irrelevante na ponderação do binómio Gregos-Bárbaros na obra: a consideração de uma eventual culpa dos helénicos. A reversão do princípio da superioridade helénica à luz do relativismo sofístico parece, pois, entrever-se nestes versos, onde, ao mesmo tempo, o confronto de duas versóes opostas do mito vem renovar a sugestáo do seu carácter ficcional.

${ }^{28} \mathrm{O}$ epíteto, em Homero atribuído a Aquiles e ao deus Hermes, dá ao quadro do rapto um sabor arcaico, sugerindo as raízes tradicionais dos elementos inovadores introduzidos na peça.

${ }^{29}$ A cena da abdução de Helena evoca claramente o rapto de Perséfone tal como é apresentado no Hino Homérico a Deméter (424), num claro reforço da inocência da protagonista. 
terra e fez de mim objecto da discórdia, da fatal discórdia entre a Grécia e [os filhos de Príamo.] Assim, nas margens do Simoente ${ }^{30}$, o meu nome (250) é alvo de injusta difamação.

\section{Coro}

Penosas são as tuas afliçôes, bem o sei. Mas deves suportar as fatalidades da vida com a máxima resignação.

\section{Helena}

Queridas amigas, que destino é este que me aprisiona? (255) Terá minha mãe gerado um prodígio para os homens? [Pois jamais uma mulher grega ou troiana deu à luz um alvo ovo de pássaro, no qual dizem que Leda de Zeus me gerou.] O certo é que a minha vida e os seus reveses são já um prodígio (260), uns por causa de Hera, outros por culpa da minha beleza. Quem dera que, branqueada como uma estátua e de novo pintada, a minha imagem, em lugar de bela, se tornasse disforme. E que a minha triste sorte assim a esquecessem os Helenos (265), guardando na memória a minha inocência como guardam agora as culpas...

Quando alguém se concentra numa só esperança e é defraudado pelos deuses, o sofrimento é penoso, mas há que suportá-lo. A mim, porém, são muitas as desgraças que me assolam. Primeiro, apesar de inocente, sou votada à infâmia. (270) E pior do que este mal, se verdadeiro fosse, é ver-me acusada de crimes que não cometi. Depois, os deuses exilaram-me da terra pátria e trouxeram-me para um país de Bárbaros. Aqui, privada dos meus entes queridos, fui feita escrava, apesar de haver nascido livre. (275) Afinal, à excepção de um, todos os Bárbaros são escravos. Uma única âncora sustinha o meu destino: a esperança de que o meu esposo viria um dia libertar-me destes sofrimentos. Esta

${ }^{30}$ Um dos rios de Tróia, a quem, na versão de Homero (Il., 21, 306323), o Escamandro pedira auxílio para punir Aquiles, responsável pela chacina do povo troiano. 
esperança, porém, desvaneceu-se com a sua morte. Minha mãe morreu e fui eu quem a matou. (280) É injusto, mas sobre mim recai esta injustiça. Minha filha, orgulho da minha casa, sem marido, continua donzela, e já as câs lhe vão despontando. Os dois filhos de Zeus, chamados Dioscuros, não vivem já. E eu, a quem todos os infortúnios atingiram (285), por toda a sorte de razões estou morta, embora viva na realidade. [Mas a pior das desgraças é que, se eu regressar à pátria, terei as portas fechadas, porque se julga que a verdadeira Helena partiu de Tróia com Menelau. Se o meu esposo estivesse vivo, reconhecer-nos-íamos através de sinais (290) que apenas para nós seriam evidentes. Mas nem mesmo essa esperança de salvação me resta.] Porque vivo eu, então? Que destino me aguarda? Refugiar-me num novo casamento e viver com um homem bárbaro, sentando-me à sua lauta mesa? (295) Quando o marido é para a mulher odioso, até a própria vida lhe causa repulsa. [Melhor é morrer. E como morrerei com dignidade? Suspender-me de um laço seria morte indecorosa e mesmo para os escravos considerada indigna.31 (300) Mais nobre e gloriosa é a morte pela espada; e é tão breve o instante que nos separa da vida!.... Sou chegada ao limite das desgraças!

Afortunadas são as outras mulheres pela sua beleza, enquanto, para mim, foi precisamente esta a causa da minha perdição. (305)

\section{Coro}

Helena, aquele estrangeiro que chegou, quem quer que seja, não tomes por verdadeiras todas as suas palavras.

31 Muito embora seja comum entre as heroínas trágicas o recurso ao suicídio como solução derradeira para uma desgraça incontornável, a ameaça de Helena, reiterada nos vv. 353-57 e de algum modo retomada nos vv. 839-50 com o pacto de morte concertado com Menelau, torna presente ao público o valor convencional deste expediente trágico, potenciando mais uma vez a reflexão metateatral. 


\section{Helena}

Mas ele afirmou claramente que o meu esposo estava morto.

Coro

Todas as certezas podem revelar-se falsidades.

\section{Helena}

E, inversamente, podem revelar-se verdadeiras. (310)

Coro

Tendes a imaginar o pior, em vez de seres optimista.

\section{Helena}

$\mathrm{O}$ medo tomou conta de mim e impele-me à desconfiança.

Coro

E tens neste palácio alguém com quem possas contar?

\section{Helena}

Todos são meus amigos, excepto o que deseja tomar-me por esposa.

Coro

Sabes o que tens a fazer? Deixa o teu assento junto a este túmulo. (315)

\section{Helena}

Que queres dizer? Que conselho me pretendes dar?

Coro

Entra no palácio e pergunta a Teónoe, a virgem nascida da Nereide marinha, aquela que tudo conhece, se o teu esposo está vivo ainda ou se já deixou a luz do dia. Logo que souberes ao certo o que a sorte te reserva (320), entrega-te, então, à alegria ou ao pranto. Porque te afliges, quando nada sabes ao certo? Confia antes em mim. [Deixa este sepulcro e procura a virgem, de quem tudo saberás. (325) Se tens nesta morada_quem te revele verdade, porquê buscar mais longe?] Também eu quero acompanhar-te ao 
palácio e contigo conhecer os oráculos da virgem. Afinal, uma mulher deve ser na dor solidária com a outra.

\section{Helena}

Aceito, amigas, os vossos conselhos. Entrai, entrai no palácio, para no interior desta morada conhecerdes as agruras que me esperam. (330)

\section{Coro}

É de bom grado que respondo ao teu apelo.

\section{Helena}

Oh, dia desafortunado! (335) Que triste história ouvirei, que as minhas lágrimas fará cair?

\section{Coro}

Não profetizes as dores, amiga, não antecipes os lamentos.

\section{Helena}

O que terá sofrido o meu pobre marido? (340) Verá ainda a luz do dia, a quadriga do sol e o curso dos astros, ou suporta, entre os mortos, no reino das sombras, um perpétuo destino? (345)

\section{Coro}

Confia num futuro melhor, seja ele qual for.

\section{Helena}

Eu te invoco, eu por ti juro, verde Eurotas, semeado de canaviais, se é verdadeiro o rumor de que está morto o meu esposo, (350) † palavras ainda pouco claras para mim $\dagger$, de um laço fatal suspenderei o pescoço ou, com força, cravarei na carne a férrea espada, num golpe derradeiro, abrindo uma ferida (355) donde brotará o sangue. Vou assim sacrificar-me às três deusas do julgamento e ao Priamida, que nas cavernas do Ida, junto aos redis, outrora habitava.

\section{Coro}

Que de ti se apartem estes males e que seja venturoso o teu destino! (360) 


\section{Helena}

Oh, desditosa Tróia! Por crimes nunca cometidos foste tu destruída e grandes infortúnios suportaste! $\mathrm{O}$ presente que de mim fez Cípris foi fonte de muito sangue e muitas lágrimas (365): † trouxe dores sobre dores, lágrimas sobre lágrimas e sofrimentos... $\dagger$ As mães perderam os filhos; as donzelas, irmãs dos mortos, depuseram os cabelos ao longo das correntes frígias do Escamandro... A Hélade fez soar um clamor, um longo clamor, (370) e rompeu em lamentos; bateu com as mãos na cabeça e, com as unhas, sulcou de sangue a delicada face. Ó ditosa Calisto $^{32}$, filha da antiga Arcádia, (375) tu que, sob a forma de quadrúpede, abandonaste o leito de Zeus, bem melhor foi o teu destino do que o meu, tu que, com a aparência das hirsutas feras e o $\dagger$ voraz olhar de leoa no semblante $\dagger$, escapaste a dolorosas penas. ${ }^{33}$ (380) Afortunada foste também tu, jovem Titânide, filha de Mérope, que, mercê da beleza, Ártemis expulsou dos seus coros na forma de uma corça de dourados chifres. Mas o meu corpo destruiu, arrasou a cidadela de Tróia e semeou a morte entre os Aqueus. (385)

(Acompanhada do coro, Helena dirige-se ao palácio,

${ }^{32}$ Filha de Licáon ou ninfa dos bosques, segundo outra versão, Calisto integrava o cortejo de jovens virgens que acompanhava Ártemis. Zeus, enamorado da jovem, tomou a forma da deusa para conseguir aproximar-se dela e consumar a uniáo. Segundo certas versóes, ao descobrir a falta de Calisto, Ártemis puniu-a transformando-a em ursa; segundo outras, foi Zeus quem, para encobrir de Hera a amante, lhe deu esta forma, ou a própria esposa de Zeus, enciumada, a responsável pela sua metamorfose. Cf. P. Grimal, op. cit., 72.

33 De acordo com J. Diggle (Euripidea - Collected Essays, Oxford, 1994, 177-78), não é de estranhar que Helena aponte como mais ditoso do que o seu (ou o de Leda) o destino de Calisto e o da filha de Mérope (381-85), ambas vítimas da dolosa paixão de Zeus. Refere o autor que esta metamorfose de seres humanos em animais, quando na sequência de um ultraje, representava para as vítimas um lenitivo para a infelicidade. 
deixando a cena livre para a entrada de Menelau $^{34}$, que faz a sua aparição em trajes de náufrago.)

\section{Menelau}

Ó Pélops ${ }^{35}$, tu que outrora em Pisa disputaste com Enómao a corrida de quadrigas, oxalá tivesses deixado a vida $†$ no tempo [em que, enganado, serviste de banquete aos deuses!...], † antes de teres concebido meu pai Atreu, (390) que, da união com

${ }^{34}$ A conveniência da retirada do coro neste momento, opção cénica rara no drama ateniense (H. Grégoire, op. cit., 63, refere apenas cinco casos de metástase coral documentados no conjunto das obras teatrais conservadas, entre tragédias e comédias), não serve apenas a conveniência da intriga, ao impedir que as cativas tomem conhecimento antecipado da chegada de Menelau, como confere a esta entrada a aparência de um novo prólogo.

${ }^{35}$ Cf. P. Grimal, op. cit., 137, 231-32, 363-64. Menelau alude nestes versos a dois episódios do mito de Pélops, seu avô. Começa por recordar a corrida de cavalos que disputou com Enómao, rei de Pisa, pela mão da princesa Hipodamia. Enamorado da própria filha, segundo algumas versôes, ou apenas porque um oráculo lhe anunciara que morreria às mãos do genro, de acordo com outras, o soberano desafiava cada um dos pretendentes para uma corrida de quadrigas, prometendo-lhes as núpcias como prémio da vitória e a morte em caso de derrota. Depois de condenados doze pretendentes, Pélops, por quem Hipodamia se enamorara, consegue vencer os cavalos divinos que Ares oferecera a Enómao, náo sem antes persuadir Mírtilo, o cocheiro real, a sabotar o carro do seu senhor. O outro episódio lendário remonta à juventude do herói. Segundo a versão tradicional, fora sacrificado pelo pai, Tântalo, que o serviu aos deuses num banquete, a fim de testar a omnisciência dos olímpicos. Sem conseguir enganá-los - apenas Ártemis, faminta, comera um dos ombros do herói -, o seu corpo foi reconstituído e a vida foi-lhe devolvida. Mais tarde, da uniáo com Hipodamia, gerou, entre outros filhos, Tiestes e Atreu, pai de Menelau e Agamémnon. Apesar de constituir um dos tópicos recorrentes no paradigma dos prólogos euripidianos, a referência, no monólogo inicial de Menelau, aos antepassados e antecedentes míticos da personagem não parece cumprir apenas um preceito ditado pela convenção. Afinal, em ambos os cenários míticos, o engano é a alavanca da acção: num dos casos, Pélops é apenas vítima de uma tentativa de enganar os deuses; no outro, é o próprio herói quem consegue lograr o rei Enómao, ao persuadir o cocheiro. O drama de Menelau, como veremos adiante, parece repetir o esquema: depois de enganado por um eidolon ilusório, será a sua vez de ludibriar o rei do Egipto, com quem rivaliza pela posse de Helena. 
Aérope, me gerou a mim, Menelau, e a Agamémnon, a célebre dupla. Estou certo - e não o digo com vaidade - de que fiz embarcar para Tróia o melhor dos exércitos, não como um tirano, que lidera as suas tropas recorrendo à força (395), mas como um comandante, a quem a juventude helénica seguiu de bom grado $^{36}$. E é possível contar os que já não vivem, bem como os afortunados que escaparam aos perigos do mar e trouxeram para a pátria os nomes dos mortos. Mas eu - desgraçado! pelas ondas revoltas do mar glauco ando errante (400) desde que destruímos as torres de Ílion e, apesar do meu desejo de regressar à pátria, não me julgaram os deuses merecedor de tal sorte. A todas as praias inóspitas e desertas da Líbia já aportei. Porém, sempre que me aproximava da pátria, (405) de novo o vento me afastava, e nunca uma brisa favorável inflou as velas da minha nau, permitindo o meu regresso à terra natal. Assim, eu, desventurado náufrago, fui atirado para esta terra depois de perder os companheiros e a minha nau desfez-se em mil pedaços contra as rochas. (410) Deste navio habilmente construído só a quilha restou. Sobre ela, a muito custo e por um golpe inesperado de sorte, consegui salvar-me a mim e a Helena, que arrebatei de Tróia e tenho agora comigo. $\mathrm{O}$ nome desta terra ou do seu povo, não o sei. A vergonha impediu-me de abordar as gentes locais (415) [não fossem querer saber o motivo destes andrajos] e, por pudor, ocultei a minha triste sorte. Quando um homem de nobre condição cai em desgraça, mais penoso é para si o sofrimento, por não lhe ser familiar, do que para aquele que foi sempre um desgraçado. A necessidade consome-me:

${ }^{36} \mathrm{Na}$ sequência das palavras de Helena no v. 276, o elogio da Democracia grega, implícito nesta tirada de Menelau, sai, por contraste, reforçado da crítica aqui tecida aos regimes tirânicos, que a sociedade helénica conotaria com o mundo bárbaro. A respeito desta concepção e da sua expressão na tragédia de Eurípides, vd. Med. (536-38), Hcld. (423-24), Andr. (665-66) e IA (1400-1401). 
não tenho alimento, (420) nem vestes com que cubra o corpo; estas que envergo, como se vê, não passam de despojos do naufrágio ${ }^{37}$. Os peplos de outrora, as sumptuosas vestes, todo o meu esplendor, tomou-mos o mar. A minha consorte, causadora de todos estes males (425), escondi-a nas profundezas de uma caverna, confiando-a à guarda dos companheiros que sobreviveram. E aqui venho eu sozinho, na esperança de conseguir o alimento necessário para os amigos que ali deixei. Ao ver este palácio cercado de muralhas (430) e este imponente pórtico, indício da opulência do seu senhor ${ }^{38}$, aproximei-me. Afinal, uma casa abastada promete aos marinheiros alguma benesse. Já dos menos abonados, nada podemos esperar, por muito boa-vontade que tenham. (Batendo à porta) Ó da casa! Não há um porteiro que aqui venha (435) para ir anunciar as minhas desgraças aos que lá dentro habitam?

(Assoma à entrada uma anciä, no papel de porteira do palácio.)

ANCIÃ

Quem bate à porta? Não achas melhor afastares-te do palácio em vez de ficares para aí postado à entrada do pátio a incomodar os meus senhores?! De contrário, serás um homem morto, porque és um Grego (440) e com o teu povo não mantemos relaçóes.

\section{Menelau}

$\dagger$ Parecem-me sensatas as tuas palavras †, anciā. Está bem, convenceste-me. Mas não te exaltes.

37 A ênfase dada aos andrajos de Menelau, a que também Helena e Teoclímeno farão referência directa nos vv. 554 e 1204, sugere a importância do traje do herói na discussão do tema verdade-aparência (vd. supra cap. 2.2.)

38 Idêntica descrição do palácio de Proteu é feita anteriormente por Teucro (68-70). O valor simbólico destas moradas é analisado no estudo introdutório (passim). 
ANCIÃ

Afasta-te! (A velha porteira empurra Menelau, enquanto lhe ordena bruscamente que se retire.) É que é meu dever, estrangeiro, não deixar nenhum Grego aproximar-se destas moradas.

\section{Menelau}

Alto! Tira as mãos de cima de mim e não me empurres à força! (445)

\section{ANCIÃ}

O culpado és tu, por não dares ouvidos ao que te digo...

\section{Menelau}

Vai lá dentro anunciar-me aos teus senhores.

\section{AnCIÁ}

Acho que transmitir a tua mensagem ia trazer-me grandes dissabores...

\section{Menelau}

Estou aqui na qualidade de náufrago estrangeiro, uma classe inviolável. ${ }^{39}$

\section{ANCIÃ}

Procura, então, outra casa, em vez desta. (450)

\section{Menelau}

Não. Vou é entrar já aqui. E faz o que te digo.

\section{AnCiã}

Pois fica a saber que estás a ser inoportuno e não tarda és expulso à força!

${ }^{39}$ Menelau alude ao direito/dever de hospitalidade (xenia) garantido aos estrangeiros em viagem. A violaçáo deste direito/dever configuraria uma ofensa à divindade protectora do hóspede ou do estrangeiro (xenos), Zeus Xenios. 
Menelau

Ai de mim! Onde está o meu célebre exército?

ANCiâ

$\mathrm{Na}$ tua terra, não duvido que fosses um homem ilustre, mas não o és aqui.

\section{Menelau}

Ó deuses! Que fiz eu para merecer tamanho desprezo?! (455)

AnCiâ

Porque se turvam os teus olhos de lágrimas? Qual o motivo desses teus lamentos?

Menelau

Os felizes sucessos de outrora ...

ANCIÃ

Não achas melhor ires-te daqui e chorares no ombro dos teus amigos?

Menelau

Mas que país é este? A quem pertence esta morada real?

ANCIÃO

É de Proteu este palácio e o país é o Egipto. (460)

Menelau

O Egipto? Ó desgraçado de mim! Até onde naveguei!

ANCIÃ

$\mathrm{O}$ que tens a censurar ao esplendor do Nilo?

Menelau

Não o censurei. Apenas lamento a minha sorte.

AnCiấ

São muitos os que sofrem. Não és tu o único.

Menelau

Bem, mas está em casa aquele que disseste ser o teu senhor? (465) 
Anciâ

Este é o seu túmulo. Agora é o filho quem reina sobre esta terra.

Menelau

E onde se encontra ele? Está fora ou em casa?

Anciân

Não está lá dentro, mas é o pior inimigo dos Gregos.

Menelau

Qual é a causa de toda essa hostilidade que agora recai sobre mim?

Anciâ

Sob este tecto vive Helena, a filha de Zeus. (470)

Menelau

O que estás dizer? Que história é essa? Explica-me novamente.

\section{Anciã}

A filha de Tíndaro, que vivia outrora em Esparta.

Menelau

Donde veio ela? O que significa tudo isto?

Anciân

Veio da Lacedemónia até aqui.

Menelau

Quando foi isso? (Aparte:) Será que não foram raptar-me a mulher à caverna? (475)

Anciâ

Antes de os Aqueus terem partido para Tróia, estrangeiro. Mas vai-te deste palácio! É que certos acontecimentos têm gerado grande perturbação no seio da casa real... Nâo vieste em boa altura... Se o meu senhor te descobrir, terás a morte como 
presente de hospitalidade. ${ }^{40}$ (480) Da minha parte, sou complacente para com os Gregos e a rispidez das minhas palavras foi ditada pelo medo que tenho do rei. (Entra no palácio.)

\section{Menelau}

Que hei-de pensar de tudo isto? Que dizer? As desgraças que acabo de ouvir superam as de antes... Pois se eu trouxe até aqui a esposa que resgatei em Tróia (485) e a deixei em segurança numa caverna, uma outra mulher, com o mesmo nome da minha, habita neste palácio. Disse a anciá que ela era filha de Zeus... Mas haverá mesmo um homem com o nome de Zeus (490) a viver nas margens do Nilo? É que Zeus há apenas um - no céu! E Esparta? Em que parte do mundo existe outra, além da que é banhada pelas correntes do Eurotas, de belos juncos? Também não se conhecem dois homens com o nome de Tíndaro. E há alguma outra terra com o mesmo nome ${ }^{41}$ da Lacedemónia ou de Tróia? (495) São questôes para que não tenho resposta. É que, ao que parece, muitos homens por esse mundo fora têm o mesmo nome, tal como uma cidade pode tê-lo igual ao de outra cidade e uma mulher ao de outra mulher. Logo, não há nisto nada de surpreendente. Não vou agora fugir com medo das ameaças

40 A nova referência à hospitalidade, agora por parte da velha egípcia, não é casual ou anódina, tendo em conta que o destino dos heróis, tanto na versáo convencional do mito como na adoptada por Eurípides, depende do respeito ou infracçáo das obrigaçóes que ao hóspede e ao anfitriáo se impóem. O contraste entre a conduta de Proteu, a quem cabe salvar Helena da desonra, e Páris, aqui representado na figura de um Teoclímeno que ameaça a integridade da protagonista e a vida do Atrida, torna-se absolutamente relevante na discussão da antítese Gregos/Bárbaros.

${ }^{41} \mathrm{O}$ problema da sinonímia, tal como é colocada por Menelau, levanta o véu da discussão sofística em redor do valor referencial da linguagem, na origem dos primeiros estudos de natureza filológica, de que o tratado de Pródico sobre sinonímia é exemplo cabal. Além do fr. I, há também referências várias ao interesse do sofista pela questão nos diálogos platónicos (Prt., 339e-341d, Men., 75e, Euthd., 277e) e em Aristóteles (Top., $2.6122 b)$. 
de uma serva... (500) Com certeza, nenhum homem tem um coração tão bárbaro ${ }^{42}$ que, ao ouvir o meu nome, me recuse alimento. [Célebre é o incêndio de Tróia, e eu, Menelau, que o ateei, não sou menos conhecido em toda a terra. Vou esperar o senhor do palácio. Tenho duas alternativas (505): no caso de se tratar de um homem cruel, escondo-me e volto para junto dos destroços do navio; mas se der mostras de benevolência, peço-lhe o necessário para fazer face à minha presente miséria.] No meio de tantas desgraças, não há para mim maior infelicidade do que esta (510) de ser rei e ter de mendigar o pão a outros soberanos. Mas a necessidade a tal me obriga. Não são minhas estas palavras, mas de um sábio: nada é mais poderoso do que a terrível necessidade... (Menelau recolhe-se junto ao túmulo.)

(Epipárodo: o coro retorna à orchêstra para anunciar as palavras da profetisa.)

\section{Coro}

Ouvi da jovem profetisa (515) as revelações que buscava quando transpus os pórticos da real mansão: Menelau não partiu para o Érebo sombrio nem a terra o oculta no seu seio, mas, penando sem descanso pelas ondas do mar, (520) não alcançou ainda o porto seguro da pátria. Numa vida de errâncias, infeliz, privado dos amigos, às mais diversas terras (525) vem aportando, levado pelo remo marinho, desde que deixou Tróia.

(Helena faz a sua entrada em cena, vinda do interior do palácio.)

\section{Helena}

E eu retomo o meu assento junto a este túmulo, agora que ouvi o auspicioso oráculo de Teónoe, [conhecedora de toda a

${ }^{42} \mathrm{O}$ termo barbaros estava, à época, conotado com a ideia de crueldade e selvajaria atribuída aos povos náo helénicos, podendo ser usado em alternativa a qualquer um destes conceitos. Acerca do estereótipo do bárbaro, vd. supra cap. 2.3.. 
verdade. Disse ela que (530) o meu esposo está vivo e contempla ainda a luz do dia: à deriva, vem cruzando os mares sem fim e navega por aqui e por ali, numa atribulada carreira de errâncias. Mas há-de vir, um dia, quando estas suas desventuras tiverem fim. Só houve um ponto que não esclareceu: se, ao chegar, se salvaria; (535) nem tive a lucidez de lho perguntar, táo feliz me deixou a notícia de que estava salvo. Revelou, no entanto, que se encontrava algures perto desta terra, depois de haver escapado a um naufrágio com uns poucos de companheiros. Ai de mim, quando chegarás? Como anseio pela tua vinda!] (540) (Encaminha-se para o túmulo, quando é surpreendida pela presença do Atrida, que, irreconhecivel, lhe sai ao encontro.) Eh lá! Quem é este homem? Não será isto uma armadilha montada por aquele ímpio, o filho de Proteu? Veloz como uma potra ou uma bacante em delírio divino, correrei a refugiar-me no túmulo. Que ar selvagem o deste homem que me persegue para fazer de mim sua presa! (545)

\section{Menelau}

Tu, que te lanças numa corrida desenfreada em direcção aos degraus da tumba e aos pilares onde ardem os fogos sacrificiais, pára! Porque foges? À vista da tua pessoa, fiquei pasmado e sem palavras!...

Helena (Procurando esquivar-se às tentativas de aproximação de Menelau)

Mulheres, estou a ser vítima de violência! (550) Este homem está a impedir-me de chegar ao túmulo; quer capturar-me para me entregar ao tirano, com quem recusei casar!

\section{Menelau}

Não sou nenhum raptor, muito menos servo de malfeitores!

\section{Helena}

Mas as vestes que te cobrem o corpo são assustadoras... 


\section{Menelau}

Pára, não temas, detém o teu passo ligeiro! (555)

Helena (chegando, finalmente, ao túmulo)

Paro, sim, agora que estou em lugar seguro!

Menelau (já próximo de Helena, olha-a de frente)

Quem és tu? Que visão é esta que contemplo, mulher?

\section{Helena}

E tu, quem és? $\mathrm{O}$ mesmo te pergunto eu.

\section{Menelau}

Nunca eu vi tal semelhança!...

\section{Helena}

Ó deuses! Divina graça a de reconhecer quem nos é querido! (560)

\section{Menelau}

$<$ És helénica ou natural desta terra?>

\section{Helena}

Sou helénica, ${ }^{43}$ mas quero também saber de ti.

\section{Menelau}

Não conheci até hoje ninguém tão semelhante a Helena, mulher!

\section{Helena}

E eu ninguém tão idêntico a Menelau. Nem tenho palavras...

\section{Menelau}

Acabas de reconhecer o mais infeliz dos homens! (565)

${ }^{43}$ Num momento em que o reconhecimento está iminente, a repetição anafórica do termo Hellenis, foneticamente muito próximo do nome da protagonista, é uma clara subtileza linguística usada por Eurípides, conhecido adepto dos jogos vocabulares, para adensar o suspense e possivelmente lembrar, sob o signo do pan-helenismo, a nacionalidade que une Atenienses e Espartanos. 


\section{Helena}

Oh! Regressa, enfim, aos braços da tua esposa!

(Helena deixa a proteç̧ão do túmulo e faz menção de abraçar Menelau, que a afasta bruscamente.)

\section{Menelau}

Que esposa?! Não toques nas minhas vestes!...

\section{Helena}

Aquela que te entregou Tíndaro, o meu pai.

\section{Menelau}

Ó refulgente Hécate ${ }^{44}$, envia-nos mais amenas visōes!

\section{Helena}

Não é um fantasma da noite ao serviço de Enódia ${ }^{45}$ o que vês. (570)

\section{Menelau}

Mas eu não posso ser esposo de duas mulheres ao mesmo tempo...

\section{HeLena}

E de que outra esposa és senhor?

\section{Menelau}

Da que trouxe comigo da Frígia e que uma caverna agora esconde.

\section{HeLENA}

Não tens nenhuma outra mulher além de mim...

${ }^{44}$ Deusa da geração dos Titãs, a quem Zeus conservou e acrescentou os poderes. Conhecida por ser uma divindade benevolente e generosa, que distribuía pelos homens toda a sorte de benesses, é neste verso invocada na qualidade de inventora da magia e protectora dos feiticeiros. Associada à noite e às sombras, a deusa era representada com um archote em cada mão, o que explica o adjectivo que lhe é neste verso atribuído, phôsphoros.

${ }^{45}$ Epíteto atribuído a Hécate, por presidir aos caminhos e encruzilhadas, locais na Antiguidade associados à magia. 


\section{Menelau}

Não estou a pensar com lucidez ou a minha vista está enferma? ${ }^{46}(575)$

\section{Helena}

Quando me olhas, não tens a sensação de estares a ver a tua esposa?

\section{Menelau}

O aspecto é idêntico, mas falta-me a certeza...

\section{Helena}

Ora observa bem! De que prova mais fidedigna precisas?

\section{Menelau}

Que és parecida com ela não posso de modo algum negá-lo.

\section{Helena}

E quem poderá esclarecer-te senão os teus próprios olhos? (580)

\section{Menelau}

Pois aí é que reside o problema: já tenho outra esposa.

\section{Helena}

Eu nunca fui para Tróia; era apenas uma imagem minha o que lá estava.

\section{Menelau}

E quem fabrica assim corpos com vida? ${ }^{47}$

\section{Helena}

O Éter, matéria em que os deuses moldaram a tua esposa.

${ }^{46}$ A recorrência de termos associados à visão, que se verifica entre os vv. 575 e 580, vem centrar o diálogo numa questão já equacionada no episódio de Teucro, a antinomia percepção sensorial/verdade.

${ }^{47}$ Nos versos 583-85, a figura de Helena surge de novo como objecto de criação artística (cf. 262-64), a recordar a importância das antinomias realidade/poesia ou verdade/ficção no permanente debate de ideias a que o argumento convida. 


\section{Menelau}

E qual dos deuses a modelou? É incrível o que me contas! (585)

\section{Helena}

Foi Hera, para impedir Páris de me capturar.

\section{Menelau}

Mas como podias estar aqui e em Tróia ao mesmo tempo?

\section{Helena}

O nome pode estar em toda a parte; a pessoa, não.

\section{Menelau}

Deixa-me, que já aqui cheguei com a minha conta de sofrimentos!

\section{Helena}

Vais abandonar-me e levar contigo uma esposa feita de nada? (590)

\section{Menelau}

Felicidades para ti, por seres tão semelhante a Helena!

\section{Helena}

Que desgraça a minha, que te encontrei para te perder de novo, meu esposo!

\section{Menelau}

Mais convincente do que tu é a dimensão do que passei em Tróia.

\section{Helena}

Pobre de mim! Há alguém mais infeliz do que eu? Abandona-me quem me é mais querido e jamais regressarei à Hélade ou à terra pátria. (595)

(Dá entrada um velho servo e companheiro de Menelau, no papel de mensageiro, e vem encontrar o seu senhor junto ao eisodos, preparado já para deixar a cena.) 


\section{Mensageiro}

Até que enfim que te encontro, Menelau, depois de muito vaguear por esta terra bárbara em tua busca, a pedido dos companheiros que deixaste.

\section{Menelau}

$\mathrm{O}$ que se passa? Não me vais dizer que foram assaltados pelos Bárbaros...(600)

\section{Mensageiro}

Um prodígio - e a palavra não é suficiente para descrever o acontecido.

\section{Menelau}

Conta lá! Com tanta pressa deves ser portador de uma verdadeira novidade.

\section{Mensageiro}

Digo-te que foram vãs as incontáveis penas que sofreste.

\section{Menelau}

Choras desgraças passadas. Que novidades trazes agora?

\section{Mensageiro}

A tua esposa desapareceu, ascendendo, invisível, aos vales etéreos. (605) Deixou a sagrada caverna onde estava à nossa guarda e eclipsou-se nos céus. Mas antes disse: «Ó desditosos Frígios e todos vós Aqueus, por minha causa perecestes junto às margens do Escamandro, ao acreditardes, enredados nas teias de Hera, que Páris tinha Helena em sua posse, sem que, na verdade, a tivesse. (610) Quanto a mim, depois de permanecer na terra o tempo que se impunha e de cumprir as determinaçóes do fado, regresso agora ao céu que me gerou. Infeliz a filha de Tíndaro que uma fama ultrajante colheu, sem ter culpa!». (615) (Reparando finalmente em Helena.) Ora viva, filha de Leda! Estavas aqui, afinal! E anunciava eu que te tinhas sumido na distância do céu 
estrelado, sem perceber que havias ganhado asas. Não permitirei que voltes a enganar-nos, pois já bastantes sofrimentos causaste, em Ílion, ao teu esposo e aos companheiros de armas. (620)

\section{Menelau}

Então é verdade! As tuas palavras coincidem com as dela. Ó dia tão desejado, que me permitiu tomar-te em meus braços! (Abraça Helena, que lhe corresponde.)

\section{Helena}

Ó mais querido dos homens, Menelau, longa foi a espera! (625) Mas a alegria chega em boa hora! Como estou feliz, amigas, por reencontrar o meu esposo e envolvê-lo com amor nos meus braços, tantos sóis volvidos...

\section{Menelau}

E eu a ti. Tantas histórias tenho, entretanto, para contar-te que nem sei por onde comece. (630)

\section{HeLENA}

$\mathrm{O}$ meu coração exulta! $\mathrm{Na}$ cabeça, eriçam-se-me os cabelos, as lágrimas correm-me pela face e estreito o teu corpo entre os meus braços para recuperar a alegria, querido esposo. (635)

\section{Menelau}

Ó visão tão amada, de nada me posso lamentar: $†$ tenho nos braços a minha esposa, filha de Zeus e de Leda. $\dagger$

\section{Helena}

Aquela que os irmãos, os gémeos de brancos corcéis ${ }^{48}$, outrora, abençoaram, e à luz dos archotes nupciais felicitaram... ${ }^{49}(640)$

${ }^{48}$ Helena refere-se aos gémeos Castor e Pólux, conhecidos como Dioscuros.

${ }^{49}$ A reunião do casal motiva esta que é a primeira referência ao cortejo nupcial de Helena e Menelau e à bênçáo (olbismos) dos Dioscuros. Outras alusóes ao casamento dos reis de Esparta e ao papel que nele desempenham os irmãos gémeos de Helena surgem adiante, nos vv. 722-25, 1431-35 e 1663-65. 


\section{Menelau}

$\mathrm{O}$ deus que um dia te arrebatou do meu palácio conduz-te agora a um destino superior...

\section{Helena}

Um feliz infortúnio nos reuniu, meu marido, depois de tanto tempo. Possa eu apenas gozar esta sorte. (645)

\section{Menelau}

Sim, oxalá possas fruí-la! A ti me junto neste voto! Pois entre nós dois não pode um ser infeliz quando o outro o não é.

\section{Helena}

(Dirigindo-se ao coro) Amigas, caras amigas, os males do passado não mais os lamento, nem volto a chorá-los! Tenho comigo o meu marido; é meu agora! Tanto tempo aguardei - longa espera! - (650) que de Tróia regressasse!

\section{Menelau}

Tens-me a mim e eu a ti! Volvidos tantos sóis, pude finalmente conhecer os estratagemas da deusa.

\section{Helena}

Choro de alegria. São de felicidade as minhas lágrimas, não de tristeza. (655)

\section{Menelau}

$\mathrm{O}$ que dizer? Quem à face da terra poderia esperar que isto acontecesse?

\section{Helena}

Longe estava eu de imaginar que te estreitaria contra o meu peito.

\section{Menelau}

Também eu, pois julgava que tinhas ido para a cidade do Ida e para as desafortunadas torres de Tróia. Pelos deuses, como foi que deixaste o meu palácio? (660) 


\section{Helena}

Oh, não! Tristes começos esses a que remontas... Ai de mim! Dolorosa é a história que procuras saber.

Menelau

Conta-ma que quero ouvi-la! Tudo é dádiva da divindade! Helena

Horrorizam-me estas palavras, estas que vou agora dizer.

\section{Menelau}

Di-las, ainda assim. É agradável ouvir falar de sofrimentos já passados. (665)

\section{Helena}

Nem o voo de uma nau me conduziu ao leito de um jovem bárbaro, nem as asas do amor a uma união adúltera.

\section{Menelau}

Entấo que divindade ou destino te arrebatou da pátria?

\section{Helena}

O filho de Zeus, meu esposo, de Zeus e de $<$ Maia $>$, foi quem me trouxe até ao Nilo. (670)

\section{Menelau}

Espantoso! Quem o enviou? Que história tão estranha!

\section{Helena}

Muito tenho eu chorado. Os meus olhos estáo ainda marejados de lágrimas... Foi a esposa de Zeus a causadora da minha desgraça.

\section{Menelau}

Hera?! Que motivo tinha ela para nos causar tanto mal? (675)

\section{Helena}

Funestos para mim foram os banhos e as fontes onde as deusas lavaram o seu corpo, a origem do julgamento. 
Menelau

...Mas que relação tem o julgamento com os sofrimentos que Hera te causou?...

Helena

Para privar Páris...

Menelau

Como? Fala! (680)

Helena

Aquele a quem Cípris me prometera.

Menelau

Ó miserável!

Helena

Miserável, sim, miserável, porque me conduziu ao Egipto.

Menelau

E em teu lugar, deu-lhe um fantasma, segundo te ouvi dizer.

\section{Helena}

E como sofreste, minha mãe, no teu palácio! Quantos sofrimentos os teus, ai de mim!

\section{Menelau}

Que queres dizer? (685)

\section{Helena}

Minha mãe está morta. Em volta do pescoço atou um laço fatal, por vergonha da minha união indigna.

\section{Menelau}

Ai de mim! E a nossa filha Hermíone, é viva ainda?

\section{Helena}

Sem marido, sem descendência, esposo meu, chora ... a desonra ... da minha união sem núpcias. (690). 


\section{Menelau \\ Ó Páris, que arruinaste por completo a minha casa! \\ Helena}

A ti mesmo te perdeste e a milhares de Dânaos de brônzeas armaduras!... A mim, desafortunada e maldita, um deus me apartou da pátria, da cidade e de ti (695), quando o lar e o teu leito deixei, embora náo por uma uniāo indigna.

Coro

Se o futuro vos reservar uma sorte feliz, o passado de infortúnio será compensado...

Mensageiro

Menelau, partilha comigo esta alegria a que assisto (700), embora não entenda bem a sua razão.

\section{Menelau}

Mas é claro, meu velho. Participa também na nossa conversa.

Mensageiro

Não foi esta a mulher que nos condenou ao sofrimento, em Ílion?

\section{Menelau}

Não, não foi ela. Fomos iludidos pelos deuses, [pois entre mãos tínhamos apenas uma pálida imagem de névoa. ${ }^{50}$ (705)

\section{Mensageiro}

[Que estás a dizer?] Que padecemos em vão por uma simples nuvem?!

\section{Menelau}

É obra de Hera o que aconteceu e resultado da disputa das três deusas.

\footnotetext{
${ }^{50}$ Cf. 1219.
} 


\section{Mensageiro}

Como? Então esta é a tua verdadeira esposa?

\section{Menelau}

A própria. Dou-te a minha palavra, quanto a isso. (710)

\section{Mensageiro}

Minha filha, como é inconstante e insondável o divino! Com que habilidade tudo revolve e tudo [muda de um lado para o outro! Pode um homem sofrer enquanto outro é poupado ao sofrimento, mas a este o futuro reserva uma morte funesta, pois não é eternamente estável a sorte de que goza. (715) A ti e ao teu esposo, une-vos o muito que padeceram: tu, mercê da infâmia; ele, em combates aguerridos. Mas apesar do esforço, nada alcançou do que almejava; agora, no entanto, foi agraciado com a máxima felicidade, que veio espontaneamente ao seu encontro.] $\mathrm{E}$ tu, não desonraste o teu velho pai nem os Dioscuros, (720) pois nada fizeste do que reza a fama. Evoco ainda o teu casamento e recordo as tochas que levava, correndo ao lado da quadriga em que seguias, recém-casada, junto ao esposo aqui presente; para trás, deixavas um lar abençoado. (725)

Mau servo é aquele que não reverencia os senhores, participando da sua alegria e partilhando os seus sofrimentos. [Já eu, embora escravo de nascença, espero entrar na conta dos servos de nobre índole ${ }^{51}$,

${ }^{51} \mathrm{O}$ adjectivo gennaios, neste verso aplicado a um escravo, relança o tópico sofístico da oposição physis/nomos, que Eurípides desenvolveu em várias das suas tragédias, a exemplo da Electra ou do Íon, não apenas sob uma perspectiva filosófica, mas sobretudo enquanto crítico social. Nesta intervenção do mensageiro, que entrelaça duas antíteses centrais no argumento - physis/nomos e onoma/pragma -, a ideia de que o título 'servo' pode ser incompatível com o espírito livre daquele a quem designa levanta, em última análise, o problema da escravatura na sociedade ateniense, por contrária que é à natureza e ao princípio da verdade. Divergente da nossa é a visão de J. Gregory ("Euripides as a social critic", G\&R 49, 2002, 160), segundo a qual esta dissociação entre o estatuto social e o carácter do indivíduo, novamente representada nos vv.1639-40, poderia, quando muito, demonstrar o carácter desnecessário de uma revisão à ordem social, que nada viria alterar no plano superior da physis. 
cujo espírito é livre, ainda que não o nome. (730) Sempre é melhor do que ver cair sobre uma só pessoa um duplo infortúnio: ter carácter servil e ser chamado de escravo pelos que o rodeiam.]

\section{Menelau}

Vá, anciāo, tu que muito sofreste, ao meu lado, no combate, (735) partilha agora comigo esta felicidade e vai anunciar aos restantes companheiros em que situação nos encontraste e como a sorte nos sorri. Diz-lhes para aguardarem junto à costa, a postos para as lutas que receio termos ainda pela frente. (740) Caso consigamos resgatar Helena desta terra, é bom que estejam preparados para nos entregarmos a um mesmo destino e escaparmos - se possível - destes Bárbaros.

\section{Mensageiro}

Assim se fará, meu senhor. Apenas vejo agora como são torpes e repletas de falsidade as palavras dos adivinhos. (745) [Nada há de verdadeiro nem no flamejar da chama nem no canto dos seres alados. Pura ingenuidade, acreditar que as aves possam auxiliar os homens!] Nem uma palavra disse Calcas e nada revelou ao exército, ao ver os companheiros morrerem por uma nuvem (750). Tão-pouco o fez Heleno; pelo contrário, deixou que a cidade fosse destruída em vão. [Poderá dizer-se que a divindade assim o quis. Para quê, então, consultar os oráculos? Há que oferecer aos deuses sacrifícios e suplicar as suas benesses, mas renunciar às profecias, que não passam de um engodo inventado para enredar o homem (755) Para mais, nenhum indolente enriqueceu graças ao fogo sacrificial. O melhor dos adivinhos é, isso sim, a inteligência e a sensatez.] (Sai de cena.)

\section{Coro}

No que aos profetas diz respeito, partilho da opinião deste velho. Quem tiver o favor dos deuses, terá em casa o melhor dos oráculos. (760) 


\section{Helena}

Enfim, até agora, tudo corre bem. Mas como escapaste de Tróia são e salvo, meu pobre homem? ${ }^{52}$ Mesmo se nada ganho em sabê-lo, quem ama tem sempre um certo desejo de ouvir as desgraças dos que lhe são queridos.

\section{Menelau}

Uma pequena e única pergunta para tâo longa resposta... (765) Porque hei-de eu falar-te do desastre no Egeu, do incêndio ateado por Náuplio na Eubeia ${ }^{53}$, das cidades de Creta e da Líbia por onde errei ou do promontório de Perseu? Decerto, não iam satisfazer-te as histórias que tenho para contar e, se te relatasse as minhas desventuras, sofreria ainda (770) ao reviver o que padeci: seria para mim um duplo tormento.

\section{Helena}

Mais acertada foi a tua resposta do que a minha pergunta. Mas diz-me apenas uma última coisa e esquece tudo o resto: quanto tempo perdeste nessas vấs errâncias sobre as ondas do mar?

\section{Menelau}

Sete anos naveguei, além dos dez passados em Tróia. (775)

\section{Helena}

$\mathrm{Ai}$, desgraçado, quanto tempo! E pensar que conseguiste escapar dali com vida para aqui encontrares a morte!...

\section{Menelau}

O que estás a dizer? Onde queres chegar? Tu matas-me, mulher!

${ }^{52}$ Trazendo à memória o pedido que Penélope faz a Ulisses após o reconhecimento do esposo, a curiosidade de Helena quanto aos tormentos vividos pelo Atrida surge como nova oportunidade para a demonstração do paralelo existente entre o atribulado percurso de Menelau (cf. 765-771) e o do rei de Ítaca.

${ }^{53}$ Cf. 1126. 


\section{Helena}

[Foge, deixa esta terra o quanto antes,] (780) ou morrerás às mãos do senhor deste palácio!

\section{Menelau}

Que fiz eu para merecer tal sorte?

\section{Helena}

A tua vinda inesperada é um entrave ao meu casamento.

\section{Menelau}

Então há aqui alguém que pretende casar com a minha mulher?!

\section{HeLENA}

E ultrajar-me, o insolente: um assédio constante, o que tenho sofrido! ${ }^{54}(785)$

\section{Menelau}

Trata-se de um indivíduo poderoso ou do soberano desta terra?

\section{Helena}

É o filho de Proteu, que reina sobre este país.

\section{Menelau}

Agora fazem sentido as palavras enigmáticas que ouvi da porteira.

${ }^{54}$ Os excessos de Teoclímeno são, nestes versos, sugeridos pelo recurso reiterado a palavras com a raiz de hybris. Integra-se assim a acçáo da personagem no conhecido esquema da tragédia clássica, segundo o qual os heróis recebem inevitavelmente uma punição pelo desafio cometido contra o princípio da justa medida. Esta subtileza estilística, bem ao gosto de Eurípides, vem, assim, chamar a atenção para o contraste que se estabelece entre o piedoso nome (onoma) do rei egípcio e a sua conduta (pragma), mais dominada pelos impulsos da sensualidade, lançando, ao mesmo tempo, o mote para uma discussáo em torno da dicotomia Gregos/Bárbaros. 


\section{HeLena}

A que portas bárbaras foste tu bater?

\section{Menelau}

A estas, donde fui expulso como um pedinte. (790)

\section{Helena}

Náo me digas que andavas a mendigar o teu sustento! Oh, desgraçada de mim!

\section{Menelau}

Era o que fazia, na realidade, mas não lhe daria esse nome..$^{55}$

\section{Helena}

Então já deves saber tudo a respeito das minhas núpcias.

\section{Menelau}

Sei. Só não estou certo de que evitaste a sua consumação.

\section{Helena}

Pois fica a saber que o meu leito se manteve intocado para ti. (795)

\section{Menelau}

Como posso estar certo disso? Que doces palavras, se for verdade o que dizes! ${ }^{15}$

\section{Helena}

Vês o meu triste refúgio neste túmulo?

\section{Menelau}

Vejo uma enxerga de folhas, infeliz! O que tem ela a ver contigo?

55 Mais uma vez, a estrutura bipartida da frase coloca em destaque a oposição onomalergon, representada pelos termos 'fazia na realidade' e 'nome'.

${ }^{56} \mathrm{O}$ diálogo entre Helena e Menelau continua a focar, com deliberada insistência, a antítese palavra/facto (onoma/pragma). 


\section{HeLena}

Estou aqui como suplicante para escapar dessa união.

\section{Menelau}

À falta de um altar ou por ser costume bárbaro? (800)

\section{Helena}

Este túmulo tem-me oferecido protecção, como um templo divino.

\section{Menelau}

Significa isso que não me é permitido levar-te pelos mares de regresso a casa?

\section{HELENA}

Uma espada te espera, em lugar do meu leito.

Menelau

Seria o mais miserável dos mortais, nesse caso.

\section{HelenA}

Então não tenhas vergonha e foge desta terra! (805)

\section{Menelau}

E deixar-te? Eu destruí Tróia por ti.

\section{HELENA}

Melhor do que ser o meu leito ${ }^{57}$ a causa da tua morte.

\section{Menelau}

Uma cobardia indigna de Tróia, isso que me propóes!...

${ }^{57}$ Decidimos manter na nossa tradução o termo 'leito' por acharmos que comporta, neste contexto, um duplo sentido: enquanto Teoclímeno luta por obter a consumaçáo da sua paixão, Menelau combate em defesa do seu direito conjugal. Apenas nos parece algo tendenciosa a leitura romântica de uma morte por amor a Helena ou pelo amor desta, como sugerem as traduçôes de H. Grégoire (op. cit., 83), Cuénca y Prado (L. A. Cuenca y Prado, C. García Gual, Eurípides. Tragedias III. Helena, Fenicias, Orestes, Ifigenia en Aulide, Bacantes, Rhesus, Madrid, 1998, 46) e J. R. Ferreira (Euripides. Helena, Coimbra, 2005, 59). 


\section{Helena}

É impossível matar o rei, como estarás provavelmente a planear.

\section{Menelau}

Tem um corpo assim tão invulnerável ao ferro?!... (810)

\section{Helena}

Logo verás. Ousar o impossível não é próprio de um homem sábio.

\section{Menelau}

Fico, então, calado e de mãos atadas?!

\section{Helena}

Não tens saída. O que precisas é de um estratagema.

\section{Menelau}

Melhor é morrer em acção do que nem sequer reagir.

\section{Helena}

Resta-nos ainda uma esperança - apenas uma - de nos salvarmos... (815)

\section{Menelau \\ O suborno, a audácia ou a palavra?}

\section{Helena}

Que o rei não descubra que chegaste...

\section{Menelau}

Ele não pode saber quem sou. E quem me vai denunciar?

\section{Helena}

É que tem ali dentro uma aliada, semelhante aos deuses.

\section{Menelau}

Queres dizer que no coração do palácio mora uma voz profética? 


\section{Helena}

Não, é a irmã dele que ali vive, a quem chamam Teónoe. (820)

\section{Menelau}

Nome perfeito para uma profetisa ${ }^{58} \ldots$ Mas diz-me então o que faz ela.

\section{Helena}

É omnisciente, logo, revelará ao irmão a tua presença.

\section{Menelau}

Nesse caso, vamos morrer, pois é impossível manter-me oculto.

\section{HeLena}

Pela súplica, talvez consigamos persuadi-la. (825)

Menelau

A fazer o quê? Que saída é essa que sugeres?

Helena

Esperar que não diga ao irmáo que te encontras nesta terra.

Menelau

E se a persuadíssemos, conseguiríamos escapar deste país?

\section{Helena}

Se estiver do nosso lado, será fácil, mas nunca à sua revelia.

\section{Menelau}

Deixo a missão a teu cargo, porque só uma mulher pode entender-se com outra. ${ }^{59}(830)$

${ }^{58}$ Acerca da relevância do nome da profetisa no contexto da peça, $v d$. p. XXX.

${ }^{59}$ Nova referência ao entendimento e solidariedade entre mulheres (cf. 329), a demarcar a fronteira entre os universos masculino e feminino na peça. 


\section{Helena}

Pois não deixarei de abraçar-lhe os joelhos. ${ }^{60}$

Menelau

Sim, mas e se ela não atender às nossas súplicas?

\section{Helena}

Morrerás. E eu, desditosa, serei forçada a casar.

\section{Menelau}

Serias uma traidora, isso sim, e invocas a força como pretexto.

\section{Helena}

Pela tua vida, faço aqui um juramento solene, juro... (835)

\section{Menelau}

Que queres dizer? Morrerás? Não partilharás o leito de nenhum outro?

\section{Helena}

Sim, cairei sob o golpe da tua espada. E junto a ti repousarei.

Menelau

Para selar este juramento, toca, então, a minha mão direita.

Helena

Ao tomá-la, juro deixar a luz do sol no dia em que morreres.

Menelau

Também eu, se te perder, porei fim à vida. (840)

Helena

Como faremos, então, para morrer em glória?

\section{Menelau}

Sobre a laje deste túmulo, dar-te-ei a morte e mato-me em

${ }^{60}$ As múltiplas referências ao código de súplica, que será, de resto, colocado em prática em diferentes momentos da acção, induzem uma reflexão de teor metateatral acerca deste popular recurso dramático. 
seguida. Mas náo sem antes travar um aceso combate em defesa do teu leito ${ }^{61}$. E tal pretendente que avance! Não desonrarei a glória troiana, nem regressarei à Hélade para ser coberto de infâmia (845), eu que privei Tétis ${ }^{62}$ de Aquiles e vi Ájax, filho de Télamon, pôr termo à vida, eu que deixei sem descendência o Nelida $^{63}$. Pois não hei-de agora considerar justo dar a vida pela minha esposa?! (850) Sem dúvida, pois, se são sábios os deuses, ao homem de coragem, morto em combate frente ao inimigo,

${ }^{61}$ Nesta sua intervenção, atravessada de inflamados arroubos de tom ultra-romântico, Menelau anuncia, embora sob uma linguagem figurada, o confronto verbal que efectivamente virá a enfrentar em defesa do seu direito de esposo, diante da profetisa. Náo é pois, casual, a figura etimológica agonal agonioumetha, que parece realçar o contributo da retórica no desenvolvimento da acção. Também a referência à sua morte e à de Helena náo deve ser lida como simples ameaça feita num clima de arrebatamento amoroso, já que a imagem descrita por Menelau corresponde, novamente no âmbito da metáfora, à morte que o casal concorda em encenar para vencer Teoclímeno, uma morte em que Helena de algum modo participa, pelo pranto fingido e no traje de luto que garante a verosimilhança cena. $\mathrm{O}$ código de actuação homérico aqui proclamado por Menelau ver-se-á, pois, preterido em favor de uma estratégia baseada na persuasáo, no que nos parece ser um deliberado movimento de aproximação do teatro à realidade coeva.

${ }^{62}$ Filha de Dóris e Nereu, Tétis é célebre entre as Nereides por ser a mãe de Aquiles (cf. P. Grimal, op. cit., 444-45.)

${ }^{63}$ Filho de Neleu, Nestor, o rei de Pilo, era o mais velho e respeitável dos guerreiros gregos que participaram no cerco de Tróia. H. Gregoire (op. cit., 85, n. 1), A. H. Cuénca y Prado (op. cit., 48, n. 16) e H. Berguin (Euripide. Théatre complet 2. Hélène, Paris, 1966, 363, n. 431) afirmam que Menelau se refere neste verso à morte de Antíloco, à qual o próprio Nestor alude na Odisseia (3. 109 sqq.) quando, em diálogo com Telémaco, o nomeia entre outros guerreiros caídos em Ílion, como sejam Aquiles e Ájax. A nossa traduçáo do termo apaida, que remata a enumeraçáo, pretende, no entanto, transmitir o sentido mais amplo dos vv. 847-49, que não se referem estritamente aos heróis nomeados, mas, de uma forma geral, a todos os guerreiros e famílias helénicas destroçados pelo flagelo da guerra. Esta nossa opção parece-nos tanto mais legítima se considerarmos que Nestor, pela sua vetustez, sabedoria e vasta prole, surge, no plano simbólico, como pai da nação grega, tal como Príamo relativamente ao povo troiano. 
cobrem-no com uma suave mortalha de terra; aos cobardes, porém, dão-lhes por túmulo o solo pedregoso. ${ }^{64}$

\section{Coro}

Ó deuses, possa um dia ser feliz a raça (855) de Tântalo e libertar-se do infortúnio!

\section{HELENA}

Oh, que infelicidade a minha: triste sina, esta!... Menelau, é o nosso fim! Vem a sair das moradas reais a profetisa Teónoe: o ranger dos ferrolhos já ressoa pelo palácio. Foge! Mas de que vale fugir?... (860) Presente ou não, é certo que já sabe da tua chegada. Que desdita a minha! Estou perdida! Salvo de Tróia e de um país de bárbaras gentes, vens de novo cair sob a ameaça bárbara!...

(Vinda do palácio, a profetisa Teónoe faz uma entrada solene na companhia de duas servas, que cumprem um ritual sagrado, purificando o ar com fumigaçóes de enxofre e o caminho com a chama de uma tocha.)

\section{TeÓNOE}

Tu que levas os archotes, guia os meus passos sob o fulgor da chama (865) e, observando o rito sagrado, purifica os recessos etéreos, para que do céu inspire o ar puro. E tu, faz passar sobre o caminho o fogo purificador, não vá um pé sacrílego tê-lo maculado, e brande contra ele a tocha, à minha passagem. (870) Depois de cumprires para com os deuses os deveres do meu culto, reconduz ao palácio a chama do lar. (Dispensadas, as servas retornam ao palácio. Teónoe dirige, então, a palavra à protagonista.) Que dizes, Helena, das minhas profecias? Chegou o

${ }^{64} \mathrm{O}$ costume de privar de honras fúnebres os cobardes e traidores está amplamente documentado na tragédia clássica (e.g. S., Aj., 1047-1420; Ant. 21-30, 45-6). 
teu esposo Menelau - aí o tens diante dos olhos -, despojado das naus e do teu simulacro ${ }^{65}$. (875) Pobre homem! Tantas provaçóes suportaste para aqui chegares e náo sabes agora se regressas a casa ou se aqui permaneces! É que os deuses, em desacordo quanto ao teu destino, tomarão hoje mesmo assento numa assembleia presidida por Zeus. Hera, outrora hostil para contigo, (880) é-te agora favorável e deseja que regresses a salvo à pátria com a mulher aqui a teu lado, para que saiba a Hélade que as núpcias de Alexandre, dádiva de Cípris, não passaram de uma falsa união. Cípris, pelo contrário, pretende impedir o teu regresso a fim de que se não torne público e notório (885) que obteve o título da mais bela à custa das núpcias ilusórias de Helena. Porém, a mim cabe o desenlace: se atendo ao desejo de Cípris e revelo a meu irmão a tua presença, condeno-te à morte; mas salvo-te a vida se ficar do lado de Hera e lho ocultar, à revelia da ordem que me deu (890) de que o informasse caso viesses um dia até estas paragens. (Dirigindo-se ao coro:) [Quem vai anunciar a meu irmáo a chegada deste homem, para minha salvaguarda?].

\section{Helena}

Oh virgem, prostrada como suplicante, abraço-te os joelhos e, do fundo da minha miséria, (895) te rogo por mim e por este homem, que tanto penei para encontrar e vejo agora a um passo da morte. Náo contes a teu irmáo que o meu bem-amado esposo tornou aos meus braços, mas salva-o - suplico-te. (900) Não sacrifiques a teu irmão a piedade, comprando o seu favor a preço de vileza e injustiça. A divindade abomina a violência e a todos manda que não adquiram pela rapina os seus bens. [Devemos, pois, renunciar à riqueza $\dagger$ quando injusta. $\dagger$ (905). O

${ }^{65}$ Cf. v. 74. De acordo com W. Allan (op. cit., 244), Eurípides é o único poeta a usar o termo mímema ('simulacro', 'imitação'), a que Platáo recorre com frequência para se referir a reproduçóes falseadas das diversas artes (e.g. Grg., passim; $L g, 798$ d). 
céu a todos pertence, tal como a terra. E não devem os homens que a habitam rechear as casas com bens alheios, usurpados ou tomados pela força]. Em boa hora, por um lado, mas para minha desgraça também, me confiou Hermes a teu pai, a fim de que me guardasse a salvo para o meu marido que, aqui presente (910), deseja agora recuperar-me. [Ora, se morrer, como pode receber-me de novo? E como poderá Proteu devolver os vivos a mortos? Considera agora a vontade divina e a de teu pai]: seria ou não desejo da divindade e do falecido (915) restituir os bens alheios? Acredito que sim. Não deves, pois, ter em maior conta um irmáo insolente do que um pai virtuoso. Se tu, que és profetisa e crês no divino, comprometeres a justiça paterna (920) em nome da fidelidade a um irmão iníquo, vergonha é que dos deuses conheças todos os desígnios, presentes e futuros, mas não o que é justo. Livra-me dos males em que, infeliz, me vejo imersa: concede-mo como uma prova mais da tua justiça. ${ }^{66}$ (925) A Helena não há entre os mortais quem a não odeie. Por toda a Hélade, corre o rumor de que abandonei o meu esposo para ir habitar os palácios frígios, ricos em ouro. Mas se regressar à Hélade e <tornar> a pisar solo espartano, poderão ouvir e ver que a sua ruína a devem a artimanhas dos deuses (930) e que não traí, afinal, o amor dos meus. Assim me será dado restabelecer a honra do passado e casar a filha que ninguém quer agora desposar; poderei, enfim,

${ }^{66}$ É de notar, nos vv. 920-25, a incidência do adjectivo díkaios (com correspondência na nossa tradução aos vocábulos 'justiça', 'iníquo' e 'justo'), que não só coloca em destaque o argumento central da súplica de Helena como contribui para a interpretação deste discurso como defesa judicial, com as implicaçôes que tem na interpretaçáo da cena. O reiterado pedido de justiça, sugerido pelo poliptoto, ajuda, pois, a determinar a função de Teónoe como árbitro de um novo julgamento que evoca o do Ida, ao mesmo tempo que lembra uma passagem da Defesa de Palamedes, da autoria de Górgias (fr. B11a, 35 D-K), onde o apelo final endereçado aos juízes congraça os argumentos da reputação e o da justiça, numa formulação bem semelhante à apresentada nestes versos. 
deixar os amargores do exílio aqui vivido para gozar das riquezas que no lar me esperam. (935) Se morresse Menelau, consumido pelas chamas, mesmo ausente, lhe faria prova do meu amor, honrando-o de longe com as minhas lágrimas. Agora que aqui está são e salvo, hei-de ver-me privada dele? Não o permitas, Virgem - imploro-te. Concede-me esta graça e imita o exemplo (940) de justiça de teu pai. Não há para os filhos de um homem íntegro maior glória que esta de igualar em virtude o carácter paterno.

\section{Coro}

Dignas de compaixăo são as palavras que aqui proferiste e digna de compaixão és também tu. Mas que argumentos invocará Menelau em defesa da vida? É o que anseio por ouvir... (945)

\section{Menelau}

Pois eu não suportaria arrojar-me aos teus joelhos ou ceder às lágrimas. Revelar tal fraqueza seria a maior das desonras para a empresa troiana. Dizem, é certo, que é próprio de um homem nobre (950) derramar lágrimas na adversidade, mas, ao invés desta virtude - se de uma virtude se trata -, prefiro a firmeza de ânimo. Se, ainda assim, te parece bem salvar este estrangeiro que reclama, por direito, a sua esposa, (955) devolve-ma e salva-me, por acréscimo. Se, pelo contrário, é outra a tua intenção, não há-de ser este o primeiro dos meus repetidos infortúnios; mas tu passarás a ser, aos olhos de todos, uma mulher cruel. Mas o que considero justo e digno de mim e o que tocará mais fundo o teu coração, (960) vou dizê-lo aqui prostrado, a abraçar o sepulcro de teu pai. (Secundando Helena no gesto de súplica, invoca a memória de Proteu.) Ó anciāo que habitas este túmulo de pedra, devolve-me - rogo-te - a minha esposa, que Zeus te confiou para que ma guardasses a salvo. Sei que, assim morto, jamais ma entregarás. (965) Mas esta tua filha não achará digno 
que um pai de nome outrora tão ilustre seja invocado do reino dos mortos por vozes de censura. A decisão pertence-lhe, agora. (Dirigindo-se, agora, ao deus infernal:) Ó Hades, senhor dos infernos, como aliado te invoco também a ti, que, por causa de Helena, recebeste tantos corpos, (970) caídos sob a minha espada. Tiveste já a devida recompensa. Pois então devolve-os à vida ou faz com que a profetisa consiga superar a piedade de seu pai † entregando-me † a esposa. (Já de pé, volta-se de novo para Teónoe.) Se, todavia, ma arrebatares, (975) o que as suas palavras calaram vou eu dizer-to. Para que saibas, ó virgem, estamos ligados por um juramento que me obriga, antes de mais, a defrontar o teu irmão num duelo. Um de nós, ele ou eu, terá de morrer: é tão simples como isto. Se, no entanto, recusar o combate corpo a corpo (980) para montar cerco ao túmulo e vencer pela fome estes dois suplicantes, ficou decidido que mataria Helena e cravaria, depois, no meu peito, aqui mesmo sobre a laje do túmulo, esta espada de dois gumes, para que o nosso sangue corresse, em torrentes, sobre o sepulcro. ${ }^{67} \mathrm{E}$ aqui havemos de jazer (985), lado a lado, sobre a tumba bem polida, para tua eterna mágoa e desonra de teu pai. A Helena, não a desposará nem o teu irmão nem nenhum outro. Sou eu quem a há-de levar, se não de volta ao palácio, então para o reino dos mortos... (990) (Com a voz embargada e tentando conter as lágrimas:) Mas que é isto? Se, como as mulheres, me entregar às lágrimas, estarei a apelar à piedade, náo a agir como um homem!... ${ }^{68}$ Mata-nos, se o

${ }^{67} \mathrm{O}$ argumento aqui invocado não é original, mas configura uma forma de chantagem já antes retratada na tragédia clássica: cf. A., Supp., 455-67 e E. IT, 973-75. No entanto, face ao perfil de justiça e piedade que caracteriza Teónoe, a ameaça de Menelau redobra a sua eficácia, tendo em conta que a morte dos reis de Esparta nestas circunstâncias redundaria num duplo sacrilégio, a ser imputado à profetisa: à contaminação de um local sagrado pelo sangue de suplicantes, somar-se-ia o desrespeito pela memória e vontade paternas.

${ }^{68}$ Menelau expressa aqui uma concepção de masculinidade cujas raízes 
entendes, pois não morreremos sem glória. Mas melhor mesmo é que as minhas palavras te demovam. Só assim serás justa e eu terei de volta a minha esposa. (995)

\section{Coro}

Compete-te, donzela, julgar o que foi dito. Trata de decidir a contento de todos.

\section{Teónoe}

Sou por natureza piedosa ${ }^{69}$ e sê-lo é também escolha minha. Tenho amor próprio e não pretendo manchar a glória de meu pai, nem prestar a meu irmáo um favor (1000) que me cubra de infâmia. Mora em mim, de nascença, o culto supremo da justiça. Herdei-o de $\mathrm{Nereu}^{70}$ e farei por conservá-lo, Menelau. Vou, pois, tomar o partido de Hera, já que vos quer ajudar. (1005) Que Cípris me seja propícia, mesmo se os nossos caminhos não se cruzam. [Afinal, aspiro a ser virgem para sempre.] Faço minhas as palavras de reprovação que disseste diante do túmulo de meu pai: injusta seria se te não restituísse a esposa (1010); e estivesse Proteu entre os vivos, já vos teria entregue nos braços um do outro. É que o castigo por tais injustiças impende sobre todos os homens, quer estejam vivos ou mortos. O espírito dos que morreram náo conserva a mesma vida, mas preserva uma consciência (1015) imortal quando se funde no Céu eterno. ${ }^{71}$ Enfim,

remontam à axiologia homérica. Já na $O d$. (8. 523-31), as lágrimas de Ulisses, que se comove ao ouvir Demódoco cantar o episódio do cavalo de Tróia, justificam a sua comparação a uma mulher que chora a morte do marido e o cativeiro iminente.

${ }^{69}$ É notória, nos vv. 998 e 1003, a alusão à antinomia physis/nomos, um dos tópicos centrais da dialéctica sofística.

${ }^{70}$ Cf. v. 15.

${ }^{71}$ Destes versos se depreende que, ao tomar esta decisão, Teónoe evita o castigo que uma injustiça poderia acarretar no Além para si própria e, na interpretação de autores como Matthiessen (apud Pulquério, op. cit., 214), também para o já falecido Proteu. No entanto, a interpretação deste passo tem gerado considerável discussáo pela complexidade que unanimemente 
para não me alongar demasiado, guardarei silêncio, em atenção às vossas súplicas, e não serei cúmplice na loucura de meu irmão. Faço-o pelo seu bem, ainda que o não pareça, (1020) ao trazê-lo assim do caminho da impiedade para o da justiça. Agora tratem vocês mesmos de encontrar uma saída. De minha parte, vou manter-me arredada e em silêncio. Comecem por elevar aos deuses a vossa súplica: roguem a Cípris que vos permita regressar à pátria (1025) e a Hera que se mantenha firme no desígnio de salvar-te a ti e ao teu esposo. E tu, meu falecido pai, no que estiver ao meu alcance, jamais colherás a fama de ímpio ao invés da de piedoso. (Regressa ao palácio.)

\section{(Helena abandona a postura de súplica.)}

\section{Coro}

Nunca um homem injusto foi apadrinhado pela sorte (1030), pois é na justiça que se fundam as esperanças de salvação.

\section{Helena}

Menelau, por parte da virgem, estamos salvos. Agora há que concentrar o pensamento num só objectivo: congeminar um plano de salvação para ambos.

\section{Menelau}

Ouve, então. Há já muito que habitas sob este tecto (1035) e que convives de perto com os servos do rei...

lhe reconhecem os estudiosos; para estes, é sobretudo problemática a ideia de que uma sanção possa ser aplicada no Além a um espírito desprovido de existência individual. Zuntz apresenta uma explicação para a aparente incongruência, sugerindo que o regresso do nous individual ao nous geral, no qual teve origem, não implica uma perda de individualidade (apud M. O. Pulquério, op. cit., 213-14). Quanto a nós, contudo, esta afirmação de Teónoe, antecipando ou não a teoria platónica da recompensa e punição das almas após a morte, como sustentam respectivamente M. O. Pulquério (op. cit., 213) e Dale (op. cit., 132), vem sobretudo assinalar com uma nota de espiritualidade a sentença de Teónoe, cuja aura de misticismo sairia comprometida se apenas a preocupaçáo com o bom nome a movesse. 


\section{Helena}

Onde queres chegar?... Dás-me esperança de que farás algo em benefício de ambos.

\section{Menelau}

Serias capaz de convencer algum dos condutores de quadrigas a ceder-nos um dos seus carros? (1040)

\section{HeLENA}

Seria. Mas como é que havemos de escapar, se desconhecemos os caminhos desta terra bárbara?

\section{Menelau}

Dizes bem: é impossível. Mas, espera: e que tal se me escondesse no palácio e trespassasse o rei com esta espada de dois gumes?

\section{HeLENA}

A virgem năo ia aceitar e muito menos calar-se ao <teu> propósito de lhe assassinares o próprio irmão!... (1045)

\section{Menelau}

Mas náo temos sequer uma nau para nos pormos a salvo... A que antes tínhamos agora ao mar pertence ...

\section{Helena}

Ora ouve - isto se é dado a uma mulher proferir palavras acertadas... Consentirias que se contasse a história de que morreste, mesmo sem teres morrido de verdade? (1050)

\section{Menelau}

Mau presságio, esse. Mas, se tiver a ganhar com ele, conta. Estou disposto a morrer em palavras, sem ter de facto morrido.

\section{HeLENA}

E eu, à maneira das mulheres, de cabelo cortado, hei-de carpir<-te> com trenos, bem à vista do ímpio. 


\section{Menelau}

Mas como pode esse estratagema conduzir-nos à salvação? (1055) É que essa história já é velha...

\section{Helena}

Farei de conta que morreste no mar e rogarei ao senhor desta terra que me deixe prestar-te, com um cenotáfio, a última homenagem.

\section{Menelau}

E supóe que ele acede: sem uma nau, como prevês que nos salve essa ideia de votar ao meu corpo um túmulo vazio? (1060)

\section{Helena}

Vou suplicar-lhe que providencie uma embarcação, de onde lançarei aos braços do mar um adorno para o teu sepulcro.

\section{Menelau}

É perfeito esse plano!... Excepto num ponto: se o rei ordenar que cumpras em terra os ritos fúnebres, o teu subterfúgio não leva a nada.

\section{Helena}

Direi, então, que na Hélade não temos o costume (1065) de sepultar em terra os que no mar pereceram.

\section{Menelau}

Agora sim, estás no bom caminho. Depois, será a minha vez de embarcar contigo e do mesmo navio lançar as oferendas fúnebres.

\section{Helena}

Sim, é fundamental que estejas ali a postos e, contigo, os marinheiros que escaparam do naufrágio. (1070)

\section{Menelau}

Assim que chegar à nau, ainda no ancoradouro, os meus homens serão dispostos lado a lado, munidos de espadas. 


\section{HeLena}

Todas as decisões estão a teu cargo. Depois, resta esperar que ventos propícios inflem as velas e conduzam a nau a bom porto.

\section{Menelau}

Assim será. Os deuses porão, enfim, termo às minhas penas. (1075) Mas de quem dirás ter recebido a notícia da minha morte?

\section{Helena}

De ti mesmo. Contarás que foste o único a escapar com vida quando navegavas com o filho de Atreu, e que o viste morrer.

\section{Menelau}

E até estes farrapos que me cobrem o corpo te podem servir de prova do naufrágio!... (1080)

\section{HeLena}

Veio em boa hora, o que era há pouco um contratempo. Num relance, pode a desgraça dar em ventura.

\section{Menelau}

Mas devo agora acompanhar-te ao palácio ou sentar-me quieto aqui junto ao túmulo?

\section{HeLena}

Espera aqui, pois, se o rei tentar contra ti algum mal, (1085) este túmulo pode oferecer-te protecção, tal como a tua espada. De minha parte, assim que entrar no palácio, cortarei os anéis dos meus cabelos, trocarei por negros os peplos brancos e, com as unhas, sulcarei de sangue $\dagger$ a pele $\dagger$ das faces. Será dura a contenda e prevejo-lhe um duplo desfecho (1090): tenho garantida a morte, se me descobrem a maquinar, ou então salvo-te e regresso à pátria. (Endereçando uma prece às deusas desavindas:) Ó venerável Hera, que no tálamo de Zeus repousas, alivia as penas destes dois miseráveis seres. A ti elevamos a nossa súplica, de braços erguidos ao céu, (1095) onde habitas entre o esplendor 
dos astros. $\mathrm{E}$ tu, que graças às minhas núpcias ganhaste o prémio de beleza, ó Cípris, filha de Dione, não me leves à ruína. Bastam as afliçóes que no passado me infligiste quando aos Bárbaros ofereceste o meu nome - embora não a minha pessoa. (1100) Porém, se é teu desejo matar-me, concede ao menos que morra em solo pátrio. Porque és insaciável de males, tu que engendras enganos de amor, pérfidas invenções e filtros que cobrem de sangue os corpos? Houvesse em ti moderação e serias para os homens a mais amável das divindades (1105) - não tenho como negá-lo. (Dirige-se para o palácio, deixando Menelau escondido junto ao túmulo.)

Coro

\section{Estrofe I}

Ó tu que em vales de frondosa folhagem fizeste a tua musical morada, eu te invoco, melodioso rouxinol de voz plangente, entre as aves canoras a primeira (1110). Vem e, com o trinado que vibra, doloroso, em teu bico fulvo, acompanha os meus trenos; pois canto os vãos tormentos de Helena e o destino dos Troianos (1115) que a lança aqueia cobriu de lágrimas, depois que em sua bárbara nau Páris cruzou a branca espuma marulhante, depois que veio de Esparta o funesto amante, sob a escolta de Afrodite, e aos Priâmidas trouxe, ó Helena, a maldição do teu leito. (1120)

\section{Antistrofe I}

Sob o golpe de lanças e pedras, muitos Aqueus expiraram e habitam agora o Hades sombrio! Infelizes, as esposas cortaram os cabelos e, nos lares, pesa ainda a ausência dos maridos. (1125) Muitos outros pereceram às mãos do homem, que, sozinho, remou até à Eubeia, cingida pelas águas: ali ateou a chama, guia de luz flamejante, e muitos Aqueus impeliu contra as rochas Cafareias, quando nas falésias do Egeu (1130) o pérfido astro fez 
brilhar. ${ }^{72}$ Atirado para inóspitas e funestas paragens, de bárbaros trajes e paramentos, viu-se Menelau afastado da pátria pelo sopro das tempestades; a bordo da nau trazia já o seu prémio - não um prémio mas o preço da luta helénica (1135) - o divino fantasma, obra de Hera.

Estrofe II

O que é a divindade, o que não é? E o que há no intervalo? Quem, de entre os mortais, poderá dizê-lo, por muito que o tenha indagado? No trilho do conhecimento, mais longe chegou quem percebeu (1140) a caprichosa inconstância dos deuses, que vão e vêm, em sentidos opostos, num revolver contraditório e inesperado da fortuna. (Evocando o destino da protagonista ausente:) Tu, Helena, filha de Zeus nasceste, pois no ventre de Leda teu pai, alado, (1145) te gerou. E por toda a Hélade veio depois proclamar-se a tua fama de mulher pérfida e infiel, sem justiça nem piedade. Não $\dagger$ creio que algum dia tenha achado verdadeira uma história que entre os mortais se contasse sobre os deuses. $\dagger$ (1150)

\section{Antistrofe II}

Insensatos de vós quantos na guerra buscais a glória, julgando em vossa ignorância que, pelo ardor vigoroso das lanças, podeis dar fim às fadigas dos mortais. Nunca a discórdia (1155) deixará

${ }^{72}$ Para vingar a sentença de lapidação atribuída ao filho Palamedes, vítima de uma intriga urdida por Ulisses, que reunira falsas evidências de que o herói planeava entregar os Gregos ao exército troiano (P. Grimal, op. cit., 348), Náuplio engendrou um plano doloso que levaria à morte um grande número de chefes gregos no seu regresso de Tróia: quando o exército aqueu se aproximou do cabo Cafareu, a sul da Eubeia, (vd. P. Grimal, op.cit., 323), aproveitou a escuridáo da noite para se dirigir aos recifes e lhes atear fogo. Os Gregos, crentes de que aquela luz intensa indicava a proximidade de um porto, navegaram de encontro às rochas, perdendo, assim, a vida e as naus. O episódio de Náuplio, já vagamente referenciado por Menelau no v. 767, torna-se, na peça, exemplar do engano potenciado pelos sentidos e das consequências nefastas que uma incorrecta percepção do real pode desencadear. 
as nações $\dagger$, se for o combate sangrento a decidir as contendas, elas que em terras de Príamo instalaram leitos de morte $\dagger$, quando pela palavra se teria dirimido a discórdia que acendeste, ó Helena. (1160) Sob a terra, jazem agora à guarda de Hades, e as chamas, qual raio de Zeus $\dagger$ flamejante $\dagger$, devastaram as muralhas, enquanto pesam sobre ti mais e mais desgraças, $\dagger$ numa triste espiral de infortúnios $\dagger$.

(Teoclimeno faz a sua entrada pela direita da skênê, acompanhado de uma comitiva de serviçais, que transporta utensilios de caça. Uma matilha de cáes completa o quadro venatório.)

Teoclímeno (Dirigindo-se para o túmulo de Proteu): Salve, ó túmulo de meu pai! (1165) Foi para assim poder saudar-te que às portas do palácio te sepultei, Proteu; à saída e à entrada, este teu filho, Teoclímeno, tem sempre uma palavra para ti, pai. (Dá instruçôes aos seus homens:) Vamos, servos, levem os cães e as redes de caça para o palácio real. (1170) (De si para si, enquanto os servos executam as ordens recebidas:) Muito eu me tenho recriminado por não punir com a morte os malfeitores! É que acabo agora de saber que um Grego penetrou nesta terra e iludiu a vigilância dos guardas. Ou se trata de um espiáo ou tem na mira o rapto de Helena ${ }^{73}$ (1175); mas, assim que o capturem, é um homem morto. (Constatando a ausência de Helena junto ao sepulcro:) Oh, não! Está-me é a parecer que já venho dar com o caso consumado! Se a filha de Tíndaro deixou o seu assento no túmulo, decerto a levaram do país a bordo de algum navio!... (Grita nova ordem aos seus servos:) Eh, companheiros, retirem os ferrolhos, abram as cavalariças (1180) e tragam para fora os carros! Não pouparei esforços para evitar que escape desta terra aquela a quem quero por esposa. (Helena entra em cena, vinda

${ }^{73}$ Para uma análise do significado da semântica venatória e sua relação com a personagem, $v d$. pp.xx 
do palácio.) Esperem! Vejo que estão, afinal, no palácio aqueles que perseguíamos: não fugiram. (1185) (A Helena:) Mulher, porque trocaste os peplos brancos pelos negros com que agora te cobres? $\mathrm{E}$ os cabelos da tua nobre fronte, porque com o ferro os cortaste? Porque se te enche o rosto de frescas lágrimas e te entregas ao pranto? ${ }^{74}$ Choras por te parecerem reais os pesadelos nocturnos (1190) ou terás ouvido alguma notícia dos teus que te minou de tristeza o coraçáo?

\section{Helena}

Meu senhor, - pois é este o nome que te dou agora - estou perdida! Foi-se tudo quanto tinha e já nada sou...

\section{TeOclímeno}

Mas que desgraça te aflige assim? Que fatalidade foi essa? (1195)

\section{HeLENA}

Menelau... - ai de mim, como o direi? - ...levou-mo a morte!

\section{TeOCLÍMENo}

[Em nada me alegram as tuas palavras, se bem que nelas vejo sorrir-me a sorte.] Como o soubeste? Foi Teónoe quem to revelou?

\section{HeLena}

Não só mo disse ela mas também o homem que testemunhou a sua morte.

\section{TeOClímeno}

Então chegou alguém capaz de contar o que de facto sucedeu? (1200).

${ }^{74} \mathrm{O}$ que faz Helena ao interpretar esta farsa diante de Teoclímeno não é mais do que levar à prática o desejo já expresso nos vv. 262-63, cumprindo assim o bem conhecido ritual feminino de lamentação fúnebre. 


\section{Helena}

Chegou! E só espero que vá para onde o meu desejo o manda! ${ }^{75}$

\section{Teoclímeno}

Quem é ele? Onde está? Quero informaçôes mais precisas.

\section{Helena}

(a indicar Menelau) É este que está aqui agachado junto ao túmulo.

\section{TeOclímeno}

(percebendo, enfim, a presença do Atrida): Por Apolo! Que aspecto miserável o das suas vestes!

\section{Helena}

Ai de mim! É neste estado que imagino também o meu esposo! (1205)

\section{TEOCLÍMENO}

Qual a origem deste homem e de onde nos chegou?

\section{Helena}

É um Grego, um dos Aqueus que navegavam com o meu esposo.

\section{Teoclímeno}

E, nas suas palavras, como foi que morreu Menelau?

${ }^{75}$ Nota D. Kovacs (Euripides. Helen, London, 2002, 143, n. 21) que na tragédia clássica os portadores de boas notícias eram agraciados com alvíssaras, sendo que o anúncio de desgraças os tornava merecedores de castigo. Assim, ao mesmo tempo que induz Teoclímeno a interpretar as suas palavras como simples imprecação contra o mensageiro da desgraça, a quem deseja uma rápida viagem para os infernos, Helena expressa veladamente o seu desejo de que Menelau consiga partir rumo à pátria e salvar-se. Nesta, como em outros passagens que oportunamente referiremos, a ambiguidade semântica não se apresenta como simples instrumento de ironia, mas pretende sobretudo ilustrar a problemática da dualidade da linguagem, retratada na sua capacidade de expressar a um tempo o falso e o verdadeiro e, neste caso particular, um desejo de morte e de vida. 


\section{Helena}

Teve a mais lamentável das mortes, nas águas revoltas do mar e... Teoclímeno

Em mares bárbaros, por onde navegava? (1210)

\section{Helena}

... foi atirado contra os penhascos inóspitos da Líbia.

\section{Teoclímeno}

E como é que este não morreu, se ia a bordo da mesma nau?

\section{Helena}

São, por vezes, mais afortunados os humildes do que os nobres.

\section{Teoclímeno}

Mas para aqui estar, onde foi que deixou os despojos do navio?

\section{HeLENA}

Onde devia ter morrido o maldito e não Menelau!... ${ }^{76}$ (1215)

\section{TeOclímeno}

Esse está morto. Mas este em que navio veio?

\section{Helena}

Recolheram-no uns marinheiros que, por sorte, o encontraram - é o que conta.

\section{TeOClímeno}

Onde está, então, a maldição que foi enviada em teu lugar para Tróia?

${ }^{76}$ À letra: «Onde devia ele morrer de má morte - não Menelau!». O esconjuro que novamente dirige (cf. 1201) ao suposto companheiro de Menelau pela triste notícia de que se faz portador parece ser, tal como sugere A. Dale (op. cit., 144), uma subtileza de Helena para evadir-se a uma questão à qual não pode dar resposta segura. Por outro lado, ao reiterar a sua hostilidade para com o mensageiro da desgraça, reforça a credibilidade da sua farsa e afasta as desconfianças perceptíveis nas anteriores réplicas do rei egípcio. 


\section{Helena}

Referes-te à imagem de névoa? Desvaneceu-se nos céus.

Teoclímeno

Ó Príamo e nação troiana, <como> foi vã a vossa ruína! (1220)

\section{Helena}

E eu compartilhei com os filhos de Príamo a desgraça!

\section{Teoclímeno}

Mas deixou o teu marido insepulto ou cobriu de terra o seu corpo?

\section{Helena}

Insepulto. Oh quanta infelicidade a minha!

\section{Teoclímeno}

Foi por isso que cortaste os caracóis dos teus louros cabelos?

\section{Helena}

É que, no meu coração, † está tão vivo aqui e agora como esteve um $\operatorname{dia}^{77} \dagger$. (1225)

\section{TEOCLÍMENo}

Bem merece as tuas lágrimas esta situação... $<$ HeLENA

$$
>\text { (lacuna) }
$$

$<$ TeOclímeno

$$
>\text { (lacuna) }
$$

${ }^{77}$ A nossa tradução procura reproduzir o hábil jogo de palavras de Helena, no qual a ambiguidade parece revestir uma dupla função: enquanto contribui para consolidar a tese da natureza ambivalente da linguagem, passível de transmitir a um tempo o verdadeiro e o falso, produz um momento de ironia cómico-trágica dramaticamente relevante. 


\section{Helena}

Achas que é fácil passar despercebido à tua irmã, não?!... ${ }^{78}$

\section{Teoclímeno}

Decerto que não. Então e agora? Vais continuar a buscar asilo neste túmulo? (1228)

\section{HeLENA}

É que, ao evitar-te, sou fiel ao meu marido. (1230)

\section{Teoclímeno}

Porque desdenhas de mim? Porque não deixas os mortos em paz? (1229)

\section{Helena}

Não mais o farei. Inicia já os preparativos das nossas bodas. ${ }^{79}$ (1231)

\section{Teoclímeno}

Vêm tarde essas palavras, mas felicito-te, mesmo assim, por elas.

\section{HeLENA}

Sabes o que há realmente a fazer? Esqueçamos o passado.

${ }^{78}$ A desadequação da resposta de Helena relativamente à observação de Teoclímeno no v. 1226 torna lógica a existência de uma lacuna entre as duas intervençóes. Por outro lado, o sarcasmo contido nesta tirada da Espartana relativamente à omnisciência de Teónoe permite supor a desconfiança manifestada pelo faraó no verso imediatamente anterior. A. Dale (op, cit., 145) avança mesmo uma hipótese de reconstituição da intervenção perdida de Teoclímeno: "How am I to know that this man's tale is true?».

${ }^{79}$ Todo o discurso de Helena parece ocultar um duplo sentido. De facto, a resposta que dá a Teoclímeno veicula a promessa oculta de que não mais deixará Menelau, o morto a quem se refere o rei egípcio. Ao mesmo tempo, ao encorajá-lo a dar início aos preparativos das suas bodas, parece ter em mente a reunião definitiva ao esposo Menelau, um reforçar dos votos que acabará por ter lugar sob o aparato de um ritual fúnebre. W. Allan (op. cit. p. 222) sugere mesmo esta identificação do falso funeral com a celebração das segundas bodas dos reis de Esparta, ao referir-se à extensa imagética nupcial patente no quadro da fuga (cf. 722-5, 1431-5, 1663-5). 


\section{Teoclímeno}

E qual a minha contrapartida? Já sabes: amor com amor se paga...

\section{Helena}

Façamos um pacto: reconcilia-te comigo. (1235)

\section{Teoclímeno}

Deixo para trás a nossa desavença: que se evole nos ares! ${ }^{10}$

Helena (assumindo, novamente, a convencional postura de súplica): Pois aqui prostrada aos teus joelhos, rogo-te, se me tens amor...

\section{Teoclímeno}

$\mathrm{O}$ que queres de mim com essa tua súplica? ${ }^{81}$

\section{HELENA}

Desejo sepultar o meu falecido esposo.

\section{Teoclímeno}

$\mathrm{O}$ quê? Um túmulo para um defunto ausente?! Ou vais sepultar uma sombra?! (1240)

\section{Helena}

É costume entre os Helenos que todo aquele que morre no mar...

${ }^{80}$ Não nos parece anódina a metáfora presente no discurso de Teoclímeno, uma antecipaçáo, a título de prenúncio, das palavras que dirá no v. 1516, ao ter conhecimento da fuga de Helena. Por outro lado, ao evocar, na mente do espectador, o desaparecimento do eidolon nos céus, este passo anuncia o fim de um passado de engano e ilusão, que se concretizará com o sucesso do plano dos esposos.

${ }^{81}$ A inversão de papéis, com Helena a montar a sua armadilha ao caçador Teoclímeno, é subtilmente sugerida pelo particípio do verbo 'caçar', usado já anteriormente para sugerir a perseguição movida pelo faraó à Espartana. Foi-nos, no entanto, impossível encontrar um vocábulo ou expressão que, no contexto, pudesse veicular eficazmente este segundo sentido. 


\section{TeOclímeno}

O que fazer? ${ }^{82}$ Nestes assuntos, os Pelópidas são entendidos...

\section{HeLENA}

...tenha por mortalha peplos vazios...

\section{TeOclímeno}

Presta-lhe, então, as honras fúnebres. Ergue-lhe um túmulo nesta terra, onde te aprouver.

\section{HELENA}

Não é desse modo que sepultamos os que morreram no mar... (1245)

\section{Teoclímeno}

Como, então? Não estou a par dos costumes helénicos...

\section{HeLENA}

Lançamos ao mar tudo o que aos finados é devido...

\section{TeOclímeno}

O que devo, então, providenciar-te para o falecido?

\section{Helena}

Quem o sabe é este homem. (Indica Menelau) Tenho a sorte de não ter passado antes por esta experiência.

\section{Teoclímeno}

Boas novas me trouxeste, estrangeiro! (1250)

\section{Menelau}

Pois não para mim, nem para o que morreu!

\section{TeOclímeno}

Como sepultam os cadáveres dos que morreram no mar?

${ }^{82} \mathrm{O}$ uso do infinitivo confere um duplo sentido à interrogação de Teoclímeno, que, ao mesmo tempo que manifesta desconfiança e dúvida quanto à decisáo a tomar, parece pedir esclarecimento a Helena sobre as medidas a empreender para a realizaçáo do inusitado funeral. 


\section{Menelau}

Depende dos bens de que cada um dispóe.

\section{Teoclímeno}

Em matéria de riqueza, pede à tua vontade tudo a que Helena tem direito!

\section{Menelau}

Primeiro, sacrifica-se aos mortos o sangue de uma vítima... (1255)

\section{Teoclímeno}

De qual? Diz-mo que eu farei por atender-te.

Menelau

Decide tu mesmo; o que deres será bem-vindo...

Teoclímeno

Entre os Bárbaros, é costume imolar um cavalo ou um touro...

Menelau

Certifica-te apenas que, a dar, não dês algum de raça impura. Teoclímeno

Boas reses não faltam nos nossos opulentos rebanhos. (1260)

Menelau

E leva-se também um esquife paramentado, sem corpo.

TeOclímeno

Seja. E que mais é costume oferecer?

Menelau

Armas de bronze, pois trata-se de um amante da guerra... Teoclímeno

Serão dignas dos Pelópidas as oferendas que lhe faremos.

Menelau

... e ainda tudo o que a terra produz de melhor. (1265) 


\section{Teoclímeno}

Como assim? De que maneira pensam lançar tudo isso às ondas?

\section{Menelau}

Precisamos que coloques à nossa disposição uma nau e remadores experientes.

Teoclímeno

E quanto é que o navio deve distanciar-se da costa?

Menelau

Até que mal se veja o rebentar das ondas em terra.

Teoclímeno

Mas porquê? Por que motivo é que a Hélade observa este costume? (1270)

\section{Menelau}

Para que a ondulação não arraste as impurezas de novo para a margem.

\section{Teoclímeno}

Será providenciado um veloz navio fenício.

Menelau

Aí estaria uma bela forma de homenagear Menelau!

Teoclímeno

E não bastava que celebrasses tu estes ritos, sem a presença de Helena?

Menelau

Essa é uma função da mãe, da mulher ou dos filhos... (1275)

Teoclímeno

Queres dizer que é sua incumbência sepultar o esposo...

Menelau

Exige a piedade que se não prive os mortos das honras que o costume prescreve. 


\section{TeOclímeno}

Que vá, então: é-me conveniente cultivar a piedade da minha esposa. Entrem no palácio e tragam de lá os adornos para o morto <

E a ti não te deixarei partir desta terra de mãos vazias, (1280) pelo favor que prestaste a Helena. Por me teres trazido felizes notícias, em lugar dos andrajos, terás vestes condignas e mantimentos, para que possas regressar à pátria, já que é de penúria o estado em que te vejo agora. (1285)

Quanto a ti, desventurada, não te mortifiques com males sem remédio. < > Cumprido está já o destino de Menelau e não é possível dar vida a um morto com lamentos.

\section{Menelau}

É este o teu dever, jovem senhora: convém que estimes o esposo aqui presente e esqueças o que já não vive. É o melhor que tens a fazer, nas actuais circunstâncias. (1290) Se chegar à Hélade são e salvo, livrar-te-ei das calúnias do passado, contanto que sejas (1293) para o teu marido a mulher que deves ser (1292).

\section{Helena}

Assim o farei. E o meu esposo jamais terá algo a censurar-me. Tu próprio estarás por perto para confirmá-lo. (1295) Mas entra, meu pobre homem, toma um banho e muda de roupa. Não tardarei em rodear-te de cuidados. Maior desvelo terás nos serviços prestados ao meu querido Menelau se tiveres da minha parte o devido tratamento. (1300)

(As três personagens entram no palácio. Em cena, permanece apenas o coro, que canta o segundo estásimo.)

Coro

Estrofe I

Um dia, a Mãe dos deuses ${ }^{83}$, que habita as montanhas,

${ }^{83}$ Claro exemplo de sincretismo religioso, Deméter é aqui identificada 
lançou-se em passo ligeiro sobre os vales cobertos de bosques, seguindo o curso dos rios e as ondas do mar bramante, (1305) na ânsia de reaver a filha ausente, de nome inefável ${ }^{84}$. Os seus címbalos ressoavam, estridentes, soltando agudos clamores, (1310) quando ao seu carro atrelou uma parelha de feras e largou $\dagger$ em busca de Core $\dagger,<\quad>$ arrebatada das rodas em que dançam as virgens. De pés velozes como ventos de tempestade, acorre Ártemis, com o seu arco, (1315) e, armada a rigor, a deusa de olhar pétreo ${ }^{85}$, brandindo a lança. Mas das suas celestes $<$ moradas, Zeus $>$, que, atento, observa, outro destino determina. ${ }^{86}$

\section{Antístrofe I}

Quando cessou o afá desta carreira errante (1320) e † penosa $\dagger$ na trilha do falaz raptor da filha ${ }^{87}$, atravessou a Mãe os cumes gelados do Ida, morada das ninfas, e deixou-se cair em dor profunda (1325) nos bosques empedernidos sob o manto da neve. Para os mortais, despiu de verde as planícies da terra < e nem pela lavra as fazia dar fruto: assim dizimava a semente dos

com Cíbele, a deusa mãe, que, oriunda de cultos orientais, surge comummente representada num carro puxado por leôes. A cena descrita inscreve-se ainda num quadro de rituais dionisíacos, com a clara fusáo de cultos a acentuar o colorido lírico desta ode, onde vigorosas sensaçóes visuais e auditivas sublinham a riqueza das múltiplas referências religiosas e culturais aduzidas.

${ }^{84}$ Os Atenienses não pronunciavam o sagrado nome de Perséfone, referindo-se-lhe como 'Core', a Virgem. Note-se, no entanto, que Helena ousa contrariar este princípio no v. 175.

${ }^{85}$ Palas Atena.

${ }^{86} \mathrm{~A}$. Dale (op. cit., 152) sustenta que o destaque concedido às armas de ambas as deusas remete para uma das versóes do rapto documentada nos Hinos Homéricos a Deméter (h. Cer., 424) e em Claudiano (Rapt. Pros., II, 204-208), autor este também mencionado por L. A. Cuenca e Prado, (op. cit., 64, n. 23). De acordo com esta versão, as deusas acompanhavam Perséfone no momento da abdução, pelo que teriam ameaçado com as suas armas o raptor; somente o desígnio de Zeus as impediu de intervirem em defesa da jovem, como, de resto, sugerem os vv.1316-18.

${ }^{87}$ Cf. v. 50, onde a referência à perseguição movida aos raptores de Helena recorre a uma construçáo semelhante, a provar a deliberada ligaçáo dos dois episódios. 
homens. Aos rebanhos, não mais concedia abundantes (1330) pastagens de erva viçosa e frisada. A vida abandonou as cidades; não havia, em honra dos deuses, sacrifícios, nem nos seus altares ardiam oferendas. Fez cessar a corrente de águas cristalinas que brotam, frescas, das fontes (1335), num luto sem fim pela filha.

\section{Estrofe II}

Como para deuses e mortais abolira os festins, quis Zeus aplacar a ira atroz da Mãe e assim falou: (1340) «Apressai-vos, Graças venerandas, ide e, com os vossos cantos de júbilo, † serenai o pesar $\dagger$ de Deo, a quem o rapto da donzela enfureceu; e vós, Musas, acorrei à deusa com hinos corais.» (1345) Cípris, de entre as Bem-Aventuradas a mais bela, foi quem primeiro fez soar a voz cava do bronze e o couro tenso dos tambores. A deusa riu e tomou nas máos (1350) a flauta de som profundo, animada com o seu alegre aulido.

\section{Antistrofe II}

$\dagger$ À revelia da lei e da piedade, fizeste arder o fogo em teus domínios † e incorreste na ira da Grande Mãe (1355), ó filha, por não cumprires em sua honra os sacrifícios divinos. Grande é o poder das peles de corça mosqueadas, do verde tenro da hera que coroa (1360) os nártex sagrados, da batida do tamborim, que volteia em círculo nos ares, dos cabelos esvoaçando para Brómio em delírio báquico, e das festas nocturnas em honra da deusa. (1365) † A lua percorria então a terra com o seu brilho fulgurante, mas tu apenas à própria beleza te devotavas $\dagger$.

(Sai Helena do palácio e relata ao coro o sucedido no plano extra-cénico.)

\section{Helena}

Por sorte, amigas, tudo no palácio nos correu de feição. A filha de Proteu ajudou-me a encobrir Menelau (1370): quando interrogada, [não revelou ao irmão] a sua presença e disse até, 
em meu favor, [que jazia morto sob a terra], sem ver já a luz do sol! $\dagger$ Da sorte que assim lhe sorria, tirou $\dagger$ o meu esposo pleno $\dagger$ partido $\dagger$ : as armas que devia lançar ao mar, (1375) tem-nas com ele; pela correia do escudo fez passar o braço valente e, com a destra, empunha a lança, como que a cumprir o seu papel nas honras fúnebres. Armado a preceito para o combate, é seu intuito triunfar, pelo próprio braço, sobre milhares de Bárbaros (1380), assim que embarcarmos na nau. Eu mesma o preparei: os andrajos de náufrago troquei-os por vestes condignas e banhei-o ${ }^{88}$, enfim, nas águas do rio, por que há muito ansiava o seu corpo. (Sai Teoclímeno das portas do palácio, na companhia de Menelau e dos seus servidores, que transportam as oferendas fúnebres.) Mas ali vem a sair do palácio aquele que se crê já meu (1385) esposo e senhor ${ }^{89}$. Melhor será que me cale. (Ao coro:) Um pedido vos faço, mulheres: < > sejam para connosco benévolas e guardem o silêncio. Se conseguirmos escapar sãos e salvos, havemos de salvar-vos um dia também.

\section{Teoclímeno}

Vamos, servos, avancem em ordem, segundo as instruçôes do estrangeiro ${ }^{90}$ (1390), e tragam as oferendas fúnebres para

${ }^{88} \mathrm{Na}$ Odisseia (23. 153-155), de modo semelhante, o rei de Ítaca é banhado e recebe vestes limpas antes do reencontro com Penélope. Os versos anunciam, pois, num quadro de associaçóes que aproxima Menelau da figura de Ulisses, a reuniáo do casal real espartano, que coincidirá com a fuga rumo à Hélade.

${ }^{89}$ Julgamos pertinente assinalar o que nos parece ser uma coincidência semanticamente relevante entre os vv. 1385-86 e o v. 35, onde a Espartana se refere a Páris em termos idênticos aos que usa agora para aludir a Teoclímeno. A falsa ilusão do faraó repete, assim, em cenário egípcio, o engano de que fora antes vítima o príncipe troiano, dando à protagonista a possibilidade de demonstrar diante do público a inocência antes declarada.

${ }^{90} \mathrm{O}$ vocabulário usado nestes versos, impregnado de sabor militar e em concordância com a panóplia que Menelau ostenta, como faz notar W. Allan (op. cit., 313), reforça o estatuto de comandante readquirido pelo Atrida após o banho ritual no palácio de Teoclímeno. 
lançar ao mar. E tu, Helena, se te não parecer insensato o meu conselho, faz o que te digo: fica. Presente ou não, poderás prestar a teu esposo a mesma homenagem. O meu receio é que, num ímpeto de saudade extrema (1395), te precipites nas ondas do mar, abalada pelas gratas memórias do esposo de outrora. É que, mesmo não estando entre nós, ainda o lamentas demasiado.

\section{Helena}

Ó meu novo esposo, é fatal que honre o tálamo onde primeiro conheci o amor nupcial. (1400) A terna afeição que tenho a meu marido seria até bastante para morrer com ele! ${ }^{91}$ Mas que benefício lhe traria a minha morte, agora que não vive? Consente, pois, que vá eu mesma prestar ao defunto as honras fúnebres. Que os deuses te concedam tudo quanto é meu desejo (1405) - e o mesmo digo aqui ao estrangeiro, por colaborar nesta missão. Como paga da tua benevolência para com Menelau e para comigo, acharás em mim a mulher a que tens direito em teu palácio. Tudo caminha, enfim, para um ditoso desfecho.92

${ }^{91}$ É, de facto, interessante notar como verdade e engano seguem a par neste discurso, onde Helena afirma o seu compromisso simultaneamente para com Teoclímeno (que reconhece como novo esposo) e Menelau. No entanto, desta retórica ambivalente há que destacar sobretudo um regresso subtil à auto-defesa da Espartana. Nestes versos, a protagonista volta, de facto, a contrariar um conjunto de acusaçóes que lhe imputara a tradição. Começa por apresentar-se como noiva virgem de Menelau (1400), quando a tradição lhe atribuíra outras relaçóes amorosas anteriores ao casamento com o guerreiro atrida, e confessa ainda o seu verdadeiro afecto pelo marido, num tom de exaltação romanesca, que não só evoca o pacto momentos antes celebrado entre os esposos (835-42) como oblitera a imagem literariamente consagrada da mulher adúltera. Por outro lado, face à pretensa morte de Menelau, as palavras de Helena náo poderiam ser entendidas pelo faraó como manifestaçáo de deslealdade ou sequer como ameaça aos seus planos, senão como prova da piedade de uma mulher extremosa no cumprimento dos seus deveres conjugais. A sagacidade de Helena confirma-se, de resto, na forma como tira partido das palavras de Teoclímeno no v. 1278 , onde o rei se mostra náo só tolerante como defensor da piedade da futura esposa.

92 A afirmação de Helena gera novamente duas interpretaçóes: se 
Ordena apenas que nos dêem um navio onde levemos as oferendas (1410) e o teu favor estará completo.

\section{TeOclímeno}

( $A$ um dos servos que o acompanha) Tu aí, anda, providencia um navio sidónio de cinquenta remos e homens aptos a manobrá-los.

\section{HELENA}

E o que preside às exéquias não deve estar também ao comando da nau?

Teoclímeno

Com certeza. Os meus marinheiros têm de obedecer-lhe. (1415)

\section{HELENA}

Repete esta ordem para que não tenham dúvidas sobre a tua vontade.

\section{Teoclímeno}

Repeti-la-ei duas e três vezes, se te apraz.

\section{Helena}

Afortunado sejas - e também eu, no que pretendo.

\section{Teoclímeno}

Pois não deixes a graça do teu rosto esvair-se numa torrente de lágrimas...

\section{Helena}

Hoje mesmo terás a prova de como te sou grata. (1420)

\section{TeOclímeno}

Os mortos já nada são e os teus cuidados inúteis.

Teoclímeno é levado a entendê-la como referência à sua união com Helena, as demais personagens (e bem assim o público) percebem nela uma alusão à fuga iminente dos esposos. 


\section{Helena}

$\dagger$ Tăo presentes estão aqui, como no além, aqueles de quem falo. † Teoclímeno

Pois não terás em mim pior esposo que Menelau!

\section{HELENA}

Nada tenho a censurar-te. Falta-me apenas a bênção da sorte..$^{93}$

\section{TEOCLÍMENo}

Isso está em tuas mãos: basta que me dediques o teu afecto. (1425)

\section{Helena}

Não é agora que aprenderei a amar quem me ama...

\section{Teoclímeno}

Queres que vá eu mesmo assistir-te e que dirija a expedição?

\section{HeLENA}

De modo algum! Não queiras servir os teus servos, senhor.

\section{Teoclímeno}

Muito bem, então. Deixo a teu cargo os costumes dos Pelópidas. ${ }^{94}$ (1430) Sobre as minhas moradas não recai mácula alguma:

${ }^{93}$ Ao desviar-se subrepticiamente do tema do casamento, aduzido por Teoclímeno no verso anterior, Helena convoca a boa sorte para os seus planos de fuga, enquanto faz crer ao príncipe que os votos expressos se referem à uniáo de ambos. A ironia resultante desta tirada ambígua da Espartana é, pois, tanto maior se tivermos em conta que, ao manifestar o seu real desejo, a personagem náo só logra manter-se livre de suspeiçôes por parte do oponente, como reforça ainda a confiança deste na sua pretensa intenção de celebrar as bodas.

${ }^{94}$ Após a alusão do coro à figura mítica de Pélops (387), é Teoclímeno quem por duas vezes (a primeira ocorre no v. 1242) se refere aos Gregos como Pelópidas, uma designação que não nos parece casual, tanto mais que ocorre em momentos onde o embuste está em vias de concretizar-se. Sobre a relação do mito de Pélops com o motivo do dolo, de que Helena e Menelau são, neste momento, actores, cf. n. XX. 
não foi aqui que Menelau entregou a alma. (Aos servos) Vá alguém dizer aos meus vassalos que tragam ao palácio as ofertas nupciais. Toda a terra deve vibrar com hinos de júbilo, para que seja digno de inveja o meu casamento com Helena. (1435) (A Menelau:) Tu, estrangeiro, vai e entrega nos braços do mar estas oferendas em honra do anterior marido de Helena. Apressa-te, então, a retornar a casa com a minha esposa, para tomares parte nas bodas ${ }^{95}$ e seguires para a pátria ou ficares entre nós, gozando de uma vida próspera. (Entra.) (1440)

\section{Menelau $^{96}$}

Ó Zeus, a quem chamam pai e deus da sabedoria, volve para nós o teu olhar e livra-nos do mal. A nós que arrastamos pelas encostas rochosas os nossos infortúnios, estende-nos sem demora a tua mão. Se apenas com a ponta de um dedo nos tocares, alcançaremos a almejada ventura. (1445) Bastam-nos as dores sofridas no passado! Muitos foram os clamores, inúteis e amargurados, que vos fiz chegar, ó deuses. Mas nada me obriga à eterna desdita; algum dia hei-de trilhar o caminho da felicidade. Concedei-me uma graça apenas e fareis de mim um homem para sempre afortunado. (1450)

${ }^{95}$ Esta inadvertida referência de Teoclímeno ao regresso de Helena a casa e à renovação dos seus votos matrimoniais faz da intervenção do rei egípcio mais um exemplo da fina ironia que perpassa toda a cena. Certo de que estáo em marcha os preparativos para o seu casamento com a Espartana, o faraó outra coisa não faz senão patrocinar a (re)união de Helena com Menelau, que ocorre sob o aparato de uma falsa cerimónia fúnebre.

${ }^{96}$ Após a prece endereçada por Helena a Cípris e Hera (1085-1106), a anteceder a primeira ode coral, Menelau suplica o favor de Zeus para o sucesso do seu plano, no momento que precede o terceiro estásimo. Esta simetria parece vincar uma divisão existente entre os universos masculino e feminino, com clara expressáo nesta tragédia. A mesma lógica está, de resto, patente nas cenas de súplica: enquanto Helena pede o favor de uma personagem feminina (Teónoe), Menelau prefere invocar a assistência de uma figura masculina (Proteu). 
(Helena e Menelau retiram-se pela saida da esquerda, em direcção à costa. Seguem-nos os servos indigitados por Teoclimeno para assisti-los no funeral, com as respectivas oferendas.)

\section{Coro}

\section{Estrofe I}

Ó nau fenícia, veloz nau de Sídon, remar amável às ondas bramantes de $\mathrm{Nereu}^{97}$, tu que lideras os belos coros de delfins quando (1455) nem uma brisa sopra sobre o mar sereno, e a filha do Ponto, Galaneia, ${ }^{98}$ de olhos glaucos, diz: «Largai as velas e não espereis as brisas marinhas. (1460) Marinheiros, vós, marinheiros, tomai os remos de pinho e conduzi Helena a bom porto, rumo à costa onde se ergue a morada de Perseu».

\section{Antistrofe I}

$\mathrm{Na}$ orla do rio (1465) ou frente ao templo de Palas, há-de encontrar as virgens Leucípides ${ }^{99}$ e juntar-se, enfim, aos coros e cânticos do festim nocturno em honra de Jacinto. ${ }^{100}$ (1470) A este, matou-o Febo, com um vigoroso remate $\dagger$ do disco redondo, apontado ao limite $\dagger$; $\dagger$ por isso, $\dagger$ decretou o filho de Zeus que em terra lacónia lhe consagrassem um dia para sacrifícios de

\footnotetext{
${ }^{97}$ Cf. p. 118 , n. 236.
}

${ }^{98}$ Deusa da calmaria e da bonança, era, no catálogo de Hesíodo (Th., 244), uma das Nereides.

${ }^{99}$ As três filhas de Leucipo, irmão de Tíndaro, eram, na tradição mitológica, mulheres dos gémeos Castor e Pólux e sacerdotisas de Palas Atena. Embora nas versóes mais recentes do mito ( $v d$. P. Grimal, op. cit., 276) se faça referência ao seu rapto, perpetrado pelos Dioscuros, a alusão às Leucípides, neste contexto, não pretende ser um regresso ao tópico da abdução, mas evocar o culto que lhes era rendido nos santuários de Esparta, ao lado de outras divindades como Jacinto, figura de resto referida nos vv. subsequentes. Neste passo, em que o coro augura o futuro auspicioso de Helena, começa já antecipar-se a deificação da personagem, que os Dioscuros vêm posteriomente anunciar em 1666-67.

100 Referência às célebres festividades realizadas anualmente em Amiclas, sul da Lacónia, em honra de Jacinto. Acerca da importância das Jacíntias na sociedade espartana, vd. Xenoph., $H G$, IV, 5, 11. 
touros. ${ }^{101}$ (1475) Finalmente, há-de Helena encontrar a filha ${ }^{102}$ $\dagger$ que deixou em casa $\dagger<$ $>$, aquela para quem as tochas nupciais não brilharam ainda.

\section{Estrofe II}

Ah, fôssemos nós seres alados para cruzar os céus, por onde seguem em fileiras os passáros da Líbia, quando deixam a chuva invernal; avançam guiados pela siringe do mais velho, o líder, que, em vôo sobre as planícies onde não chove e os campos são férteis, (1485) faz soar o seu grito. Ó aves aladas de longo colo ${ }^{103}$, rivais na carreira das nuvens, voai, a meia rota, sob as Plêiades e, de noite, sob Oríon; (1490) quando pousardes junto ao Eurotas, anunciai, então, que Menelau tomou a cidade de Dárdano e regressará a casa.

\section{Antistrofe II}

E por fim vós, jovens Tindáridas, vinde também e irrompei pelos ares, seguindo a rota dos vossos corcéis. (1495) Vós, que habitais os céus, sob a vertiginosa espiral dos astros resplandecentes, salvai Helena: descei sobre as glaucas ondas marinhas, (1500) sobre o azul-escuro das vagas, sobre a branca espuma do mar revolto, e, da parte de Zeus, enviai aos marinheiros o sopro de ventos propícios. (1505) Afastai da vossa irmã a infâmia de uma união bárbara, castigo que expiou pela disputa no Ida,

${ }^{101}$ Amado por Apolo pela sua excepcional beleza, Jacinto morreu vítima de um disco desviado por Zéfiro (ou Bóreas, em outras versóes), que o atingiu na cabeça durante uma competição realizada entre os olímpicos. O sangue do herói foi, então, transformado por Apolo numa flor, à qual foi dado o seu nome, e imortalizado nos festivais a que nestes vv. se faz referência. Cf. P. Grimal, op. cit., 257-58.

102 Nova referência a Hermíone (cf. 282-83), que expiava, com a sua virgindade, a infâmia atribuída à mãe.

103 Grous, espécie de aves migratórias que, segundo Dunbar (apud W. Allan, op.cit., 325), atravessavam a Hélade, vindas do norte em direcção aos vales fluviais do Sudáo e Etiópia. Isto aconteceria a meio do seu percurso migratório, na altura do ano em que as constelaçóes referidas nos vv. 148990, as Plêiades e Oríon, eram visíveis em território grego. Cf. Ar., HA 614b. 
mesmo jamais tendo estado em terras de Ílion (1510) ou nas torres de Febo. ${ }^{104}$

(Ao mesmo tempo que se assiste à entrada de Teoclimeno pela porta do palácio, vê-se chegar a correr, vindo da costa, o segundo mensageiro, visivelmente transtornado.)

Mensageiro

$\dagger$ Senhor, descobrimos nesta casa as piores conjuras! † E são bem inesperadas as desgraças que estás prestes a ouvir da minha boca! $\dagger$

\section{Teoclímeno}

Mas que se passa?

\section{Mensageiro}

Trata de arranjar outra mulher com quem casar, que Helena já deixou este país. (1515)

Teoclímeno (com ironia)

Elevou-se nos ares com um bater de asas?! Ou foi por terra, pelo seu pé?

\section{Mensageiro}

Foi Menelau quem por mar a levou do país, o mesmo que veio anunciar a própria morte.

\section{TeOclímeno}

Terríveis notícias, essas! Mas que navio a conduziu para fora do país? Mal posso crer no que contas! (1520)

\section{Mensageiro}

Aquele que tu mesmo deste ao estrangeiro. E partiu com os teus marinheiros - para que o saibas em poucas palavras.

${ }^{104}$ A expressão refere-se às muralhas da cidadela troiana, que Febo e Posídon foram obrigados a construir, como castigo por uma conjura fracassada que haviam planeado, juntamente com Hera e Atena, contra o pai dos deuses. 


\section{Teoclímeno}

Como? - é o que estou ansioso por saber. Que um só braço tenha vencido todos os marinheiros com quem embarcaste é algo que está para além de todas as expectativas! (1525)

\section{Mensageiro}

Depois de deixar este palácio real, a filha de Zeus foi conduzida até ao mar. À medida que avançava em passo lânguido, astuta como ninguém, lamentava-se pelo marido, que não estava morto, afinal, mas bem ali, a seu lado. Chegados ao teu estaleiro, (1530) lançámos às águas uma nau sidónia, ainda por estrear, com a medida de cinquenta bancos e remos. Uma a uma, sucediam-se as tarefas: um erguia o mastro; outro dispunha os remos $\dagger$ em fileira, prontos a manobrar $\dagger$; $\dagger$ desfraldavam-se, a um tempo, $\dagger$ as velas brancas (1535) e fazia-se descer o leme até à água, preso por correias. Andávamos nós assim afadigados, quando os Helenos, companheiros de Menelau, que ali estavam à espreita da oportunidade, se acercaram da costa, em andrajos de náufragos. Eram homens de belo talhe, mas de aspecto imundo! (1540) Ao vê-los aproximar-se, logo o filho de Atreu os interpelou, ostentando, diante de todos, uma falsa compaixão: "Ó desgraçados, em que nau aqueia viajavam vocês e como foi que o navio naufragou? Bem, juntem-se a nós na homenagem fúnebre ao Atrida falecido, (1545) que aqui a filha de Tíndaro, na ausência do corpo, pretende sepultar em cenotáfio». E ei-los que derramavam lágrimas fingidas à medida que subiam a bordo do navio, transportando as oferendas para lançar ao mar em honra de Menelau. Entre nós, havia já uma suspeita e, uns com os outros, comentávamos o número excessivo de novos passageiros. (1550) Guardámos, no entanto, o silêncio, em atenção às tuas palavras. A verdade é que, ao ordenares 
que se desse o comando da nau ao estrangeiro, deste azo a esta hesitação. As demais oferendas, por serem leves, colocámo-las facilmente no interior da nau. Mas o touro (1555) resistia em avançar a direito sobre a prancha e mugia, revirava os olhos nas órbitas, arqueava o dorso e olhava de revés por entre os cornos, tentando impedir que lhe tocassem. O marido de Helena bradou, então: "Vós que arrasastes a cidade de Ílion, (1560) vamos, carregai o touro sobre os vossos ombros jovens, como é o costume entre os Helenos, e largai-o na proa» - $\dagger$ diz, enquanto desembainha a espada, agora a postos $\dagger$ - "para ser oferecido ao morto em sacrifício.» Seguindo a sua ordem, os homens ergueram (1565) o touro, levaram-no e depositaram-no sobre o estrado. Quanto ao cavalo, Menelau afagou-lhe o pescoço e a fronte e assim o levou a entrar no barco. Por fim, depois de se acomodar toda a carga no navio, Helena subiu os degraus, em passo ágil, (1570) e foi sentar-se entre os bancos dos remadores; junto a ela, ficou Menelau, aquele que se dizia estar morto. Os outros dispuseram-se em grupos iguais nos flancos direito e esquerdo do navio, um após outro, com as espadas ocultas sob as vestes. E o marulhar das ondas (1575) era abafado pelo nosso grito de resposta ao incitamento do comitre. Estávamos já a alguma distância da praia, mas não demasiado afastados, quando o timoneiro perguntou: «Estrangeiro, navegamos mais para diante ou estamos bem, já? É a ti que cabe o comando da nau». (1580) Respondeu-lhe ele: "Para mim, é suficiente.» E de espada na mão direita, avançou para a proa, colocou-se a postos para o sacrifício do touro e, sem mencionar qualquer defunto, degolou-o, com esta prece: "Tu que habitas os mares, ó Poseidon, senhor do Ponto, e vós, castas filhas de Nereu, (1585) levai-nos desta terra, sãos e salvos, a mim e à minha consorte, até às costas de Náuplia.»E o sangue jorrava em torrentes até 
ao mar, ditoso presságio para o estrangeiro. Houve, entấo, alguém que disse: «Esta viagem é um embuste! Rumemos de novo à costa! Assume tu $\dagger$ o encargo $\dagger$ da chefia (1590); e tu, vira o leme.» Ali mesmo do local onde imolara o touro, o filho de Atreu bradou aos companheiros: «De que estais à espera, ó fina flor da terra helénica? Sacrificai, aniquilai estes bárbaros e lançai-os, borda fora, para as ondas!» E o comitre gritou aos teus marinheiros (1595) a ordem de contra-ataque: «Força! Levante um de vós uma tábua, em jeito de lança, parta outro os bancos e um terceiro retire o remo do escalmo! Fazei correr o sangue da cabeça destes estrangeiros inimigos!». Todos se ergueram de rompante, uns com tábuas do navio, outros de espada em punho. (1600) Uma corrente de sangue varria a nau, enquanto Helena, da popa, os incitava: «Onde está a glória de Tróia? Mostrai-a a estes Bárbaros.» No ardor da refrega, uns tombavam e tornavam a erguer-se, mas via-se outros que jaziam (1605) já sem vida. Menelau, armado a rigor e atento aos locais onde estivessem companheiros em apuros, brandia a espada na máo direita, forçando os teus marinheiros a escapar a nado do navio e a abandonar os remos. (1610) Dirigiu-se, em seguida, ao timoneiro e ordenou que conduzisse o navio rumo à Hélade. Içaram, então, o mastro e ventos favoráveis sopraram. Assim se foram desta terra. E eu, para escapar ao morticínio, desci pela âncora até ao mar. Sentia-me já desfalecer, quando um pescador (1615) me recolheu e veio deixar-me na praia para que te relatasse o sucedido. Nada há de mais útil aos mortais do que uma prudente desconfiança. (Sai de cena.)

Coro

Jamais poderia esperar, meu senhor, que Menelau conseguisse ocultar-nos, a ti e a nós, a sua presença, como ocultou. (1620) 


\section{Teoclímeno}

Ó infeliz de mim, presa de artimanhas femininas! Lá se me vão as núpcias!... Se com uma perseguição ao navio nos fosse possível alcançá-lo, não pouparia tempo ou esforços na captura dos estrangeiros. Mas, por agora, tratarei de punir a minha irmã, a traidora que viu Menelau nesta morada e não mo revelou. (1625) Assim, não mais enganará outro homem com as suas profecias! (Precipita-se para o palácio, mas é interceptado por um servo, que o impede de prosseguir.)

SERVO

$\mathrm{Ei}$, onde vais tu, meu senhor? Que crime estás em vias de cometer?

\section{Teoclímeno}

Vou onde a justiça me ordena. Mas afasta-te do caminho!

\section{Servo}

Não pretendo largar-te as vestes. Estás a precipitar-te para um crime horrível!

\section{Teoclímeno}

Atreves-te a mandar no teu senhor, tu que és um escravo?

SERVo

Já que me assiste a razão... (1630)

Teoclímeno

Pois eu não penso o mesmo. Se não me deixares...

Servo

Não, podes estar certo de que não te deixarei...

Teoclímeno

...dar morte à mais vil das irmãs...

Servo

Pelo contrário, a mais piedosa... 
Teoclímeno

... que me atraiçoou...

Servo

Uma nobre traição, pois fez valer a justiça...

Teoclímeno

... ao entregar a outro a minha esposa...

Servo

Que mais direitos tinha.

Teoclímeno

Quem pode ter mais direito sobre o que é meu?

Servo

O que a recebeu do seu pai. (1635)

Teoclímeno

Mas a mim concedeu-ma a sorte.

Servo

E o destino retirou-ta.

Teoclímeno

Não te compete julgar os meus actos!

Servo

Se nas minhas palavras há mais sensatez ...

Teoclímeno

Agora, em vez de comandar, recebo ordens?

SERVO

Quando se trata de agir de forma recta e não contra a lei...

Teoclímeno

Pareces desejoso de morrer!...

Servo

Mata-me. Mas a tua irmã, não consentirei que a mates. 
Tira-me, antes a mim, a vida, pois morrer pelos senhores (1640) é para os escravos de alma nobre a maior das glórias.

(Surgem, ex-machina, os Dioscuros.)

\section{CASTOR $^{105}$}

Refreia a ira que te desvia da justiça, Teoclímeno, senhor desta terra. Somos nós, os gémeos Dioscuros, quem te apela, nós que nascemos de Leda, mãe de Helena, a que do teu palácio acaba de evadir-se. (1645) Exaltas-te por umas núpcias que te não estavam destinadas; e sequer tua irmã Teónoe, filha donzela da divina Nereide, cometeu contra ti uma injustiça, ao honrar os desígnios dos deuses e os justos preceitos de teu pai. [Até ao presente dia, (1650) Helena estava fadada a residir em teu palácio. Mas depois de arrasados os fundamentos de Tróia e de haver cedido aos deuses o seu nome, não o está mais.] Agora, é seu dever reatar os laços da primeira uniáo, tornar a casa e ali viver ao lado do esposo. (1655) Portanto, afasta da tua irmá a negra espada e compreende que agiu com sensatez. Já há muito teríamos salvo a nossa irmã, pois que Zeus fez de nós divindades. Mas éramos inferiores ao destino (1660) e aos deuses, que assim o decretaram. Vão para ti estas minhas palavras. À minha irmá, por sua vez, digo: «Navega com o teu esposo: tereis vento favorável. Nós, teus irmãos gémeos e protectores, a cavalo sobre o Ponto, guiar-te-emos à pátria. (1665) E quando dobrares a meta, finda a carreira da vida, serás celebrada como deusa106; [tomarás parte

${ }^{105} \mathrm{O}$ surgimento ex-machina dos Dioscuros repete um procedimento cénico muito usado por Eurípides, facto que lhe vale inclusive uma crítica por parte Aristóteles na Poética (54a). Apresentando-se ao público como astros, a primeira das versóes referidas por Teucro quando interrogado acerca do seu destino, a figura dos gémeos torna-se promissora de uma viagem segura para o casal régio, recordando, por oposição, a dolosa orientação da estrela de Náuplio (1130-31) que atirara para a morte os marinheiros gregos.

${ }^{106}$ Com esta referência ao culto de Helena, do qual fazem prova os muitos santuários que lhe foram erigidos em território grego, pretende 
nas libações aos Dioscuros,] e, connosco, receberás dos homens os dons da hospitalidade ${ }^{107}$ Foi esta a vontade de Zeus. Já a terra onde primeiro se deteve o filho de Maia, (1670) quando contigo viajava através dos céus, ele que te havia arrebatado de Esparta para que Páris se não unisse a ti - refiro-me à ilha que se perfila, qual guardiã, ao longo da costa da Ática - essa será doravante conhecida entre os mortais pelo nome de "Helena» ${ }^{108}$, por te ter acolhido quando de tua casa foste levada. (1675) Quanto a Menelau, homem errante, os deuses destinam-lhe por morada a Ilha dos Bem-Aventurados. ${ }^{109} \mathrm{~A}$ verdade é que as divindades não odeiam os homens de nobre estirpe, mas $\dagger$ as desgraças impendem $\dagger$ sobretudo sobre a multidão dos humildes.

Eurípides conciliar a imagem de uma Espartana reabilitada com a tradição mítico-religiosa que faz dela uma deusa. A sacralização da figura de Helena e principais locais de culto é tema abordado de forma sistemática por W. Allan (op. cit., 14-16).

${ }^{107}$ De acordo com W. Allan (op. cit. 342-43), é esta a primeira vez em que Helena surge associada à celebraçấo da Theoxenía, festividade grega na qual os Dioscuros assumem um lugar de relevo. Apesar de ser frequente em Eurípides a invenção, por conveniência da trama, de etiologias relativas a cultos e rituais helénicos (Allan lista alguns dos passos mais significativos), autores como R. Parker (apud W. Allan, op. cit., 343) referem a presença, ainda que secundária, de Helena em rituais dedicados inicialmente aos gémeos Castor e Pólux.

${ }^{108}$ Ilha situada a sudoeste da costa da Ática, actualmente denominada Makronissos. Também patente na obra de autores antigos como Hecateu de Mileto ou Estrabão (apud W. Allan, op. cit., 343-44), a tentativa de relacionar o topónimo com o episódio da guerra de Tróia, aqui a obrigar à invenção de um pormenor alheio à tradição mitopoiética, corrobora o propósito de Eurípides de inscrever a sua nova versão do mito na matriz cultural helénica e garantir-lhe, assim, uma mais fácil adesão por parte de um público conservador.

${ }^{109}$ A referência tem já eco na epopeia de Homero. De facto, também na Odisseia (4. 561-69), Proteu dá a saber a Menelau que não será comum o seu destino, mas que há-de habitar os Campos Elíseos, por determinação dos imortais. Também herdeira da tradição épica, esta compensação do sofrimento dos heróis por meio de honras de culto, que a Helena e Menelau são atribuídas nos versos finais, vem selar definitivamente a estreita proximidade da versão euripidiana com a matriz literária em que se funda. 


\section{Teoclímeno}

Ó filhos de Leda e Zeus, (1680) renunciarei às minhas antigas desavenças para com a vossa irmã. E não pretendo já matar a minha. Que Helena regresse a casa, se é essa a vontade dos deuses. (1683) Ficai ambos cientes de que em vós † corre o mesmo sangue $†$ de uma irmã que é de todas a mais íntegra e virtuosa. (1685) Felicito-vos, enfim, por Helena, dona de tão nobre alma, singular entre as mulheres.

(Saem os Dioscuros e Teoclímeno, que regressa ao palácio.)

\section{[Coro}

Muitas formas assume o divino; muitos feitos realizam os deuses que nos enchem de surpresa. $\mathrm{O}$ que se espera não se cumpre, mas a divindade sempre encontra um caminho para o inesperado. (1690) ]110

E assim termina esta história...

${ }^{110}$ Considerados espúrios por muitos autores, estes versos corais, repetidos com ligeiras alterações nas tragédias Alceste, Medeia, Andrómaca e Bacantes, constituem quanto a nós um remate lógico para uma peça onde a tradição e a inovação se equilibram. Ao reflectir sobre o modo imprevisível como actua a divindade no destino dos homens, ao mesmo tempo que explora as noçóes de incerteza e arbitrariedade, inviabilizadoras de todo o conhecimento humano, Eurípides consegue o casamento perfeito entre o pensamento antigo e o coevo, modelado pelas novas ideias da sofística. Discutir a autoria dos versos parece-nos, pois, irrelevante, já que sintetizam na perfeição a filosofia euripidiana, de que esta peça, mais do que qualquer outra, é documento. 



\section{Bibliografia}

\section{EdiçóES E COMENTÁRIOS}

\section{Aristófanes}

M. F. Silva, Aristófanes. As mulheres que celebram as Tesmofórias, Coimbra, ${ }^{2} 1988$.

\section{Aristóteles}

A López-Eire, Aristóteles. Poética, Madrid, 2002.

\section{Cáriton}

M. F. Silva, Cáriton. Quéreas e Calírroe, Lisboa, 1996.

\section{Ésquilo}

D. Page, Aeschyli septem quae supersunt tragoedias, Oxford, 1985.

M. O. Pulquério, Ésquilo. Oresteia, Lisboa, 1998.

\section{Euripides}

W. Allan, Euripides. Helen, Cambridge, 2008.

H. Berguin, Euripide. Théatre complet 2, Hélène, Paris, 1966.

F. Chapoutier, H. Gregoire, Euripide. Hélène, Les Phéniciennes, V, Paris, 1961.

L. A. Cuenca y Prado, C. García Gual, Eurípides. Tragedias III. Helena, Fenicias, Orestes, Ifigenia en Áulide, Bacantes, Rhesus, Madrid, 1998.

A. M. Dale, Euripides. Helen, Oxford, 1967.

J. Diggle, Euripidis Fabulae. Tomus I, Oxford, 1984.

— Euripidis Fabulae. Tomus II, Oxford, 1981.

—, Euripidis Fabulae. Tomus III, Oxford, 1994.

—, Euripidea. Collected Essays, Oxford, 1994.

J. R. Ferreira, Euripides. Helena, Coimbra, 2005. 
Eurípides. Andrómaca, Madrid, 2000.

H. Grégoire, Euripide. Hélène, Les Phéniciennes, V, Paris, 1961.

D. Kovacs, Euripides. Helen, London, 2002.

M. H. Rocha Pereira, Euripides. As Troianas, Coimbra, 2004.

\section{Heródoto}

A. Fraschetti, Erodoto. Le Storie (Libro II) - L'Egitto, Milano, ${ }^{3} 1996$.

\section{Hesíodo}

A. Jiménez y A. Díez, Hesíodo. Obras y fragmentos, Madrid, 1978.

R. Merkelbach, M. L. West, Fragmenta Hesiodea, Oxford, 1967.

\section{"Homerica"}

H. Foley, The Homeric Hymn to Demeter. Translation, commentary and interpretive essays, New Jersey, 1994.

F. Lourenço, Homero. Ilíada, Lisboa, 2005.

— Homero. Odisseia, Lisboa, 2003.

H. van Thiel, Homeri Ilias, Hildesheim /Zürich / New York, 1996. Homeri Odyssea, / Zürich / New York, 1991.

\section{Platáo}

J. R. Ferreira, Platão. Fedro, Lisboa, 1997.

L. Méridier, Platon. Cratyle, Paris, 2003.

A. E. Pinheiro, Platão. Protágoras, Lisboa, 1999.

M. O. Pulquério, Platão. Górgias, Lisboa, 1992.

M. H. Rocha Pereira, Platão. República, Lisboa, 2001.

\section{Poesia grega arcaica}

D. Campbell, Greek Lyric I. Sappho and Alcaeus, London, 1990.

M. Davies, Poetarum Melicorum Graecorum Fragmenta, vol. I, Oxford, 1991. 
E. Lobel e D. Page, Poetarum Lesbiorum Fragmenta, Oxford, 1963.

\section{Sofistas e pré-socráticos}

H. Diels, W. Kranz, Die Fragmente der Vorsokratiker Griechisch und Deutsch, Dublin/ Zürich, 1966.

J-P. Dumond, Les Sophistes. Fragments et témoignages, Paris, 1969.

G. Lanata, Poetica Pre-Platonica. Testimonianze e frammenti, Firenze. 1963.

\section{Tucídides}

J. Romilly, L. Bodin, Thucydide. La guerre du Péloponnèse - livres VI et VII, vol. 5, Paris, 1955.

J. Romilly, R. Weil, Thucydide. La guerre du Péloponnèse - livre VIII, vol. 6, Paris, 1972.

\section{Estudos}

A W. H. Adkins, 'Homeric values and homeric society', JHS 91, 1971, 1-14.

- 'Homeric gods and the values of homeric society', JHS 92,1972, 1-19.

P. Albini, 'Prologo e azione in Euripide', Acme 40,1987, 31-50.

U. Albini, “Miracolo e avventura nell'Elena”, PP 152, 1973, 326-342.

W. G., Arnott, "Euripides and the unexpected”, G\&R 20, 1973, 4954.

_- "Off-stage cries and the choral presence: some challenges to theatrical convention in Euripides", Antichton 16, 1982, 3543.

—_, "Euripide's newfangled Helen”, Antichthon 24, 1990, 1-18.

J. Assaël, "Les transformations du mythe dans l'Hélène d'Euripide", Pallas 33, 1987, 41-54. 
H. H. Bacon, Barbarians in Greek tragedy, New Haven, 1961.

E. Barnes, "Greek tragicomedy”, CJ 60, 1964,125-131.

L. Biff, "Elementi comici nella tragedia greca", Dioniso 35, 1961, 89102.

E. M. Blaicklock, The male characters of Euripides. A study in realism, Wellington, 1952.

R. Blondell, M.-K. Gamell, N. S. Rabinowitz, B. Zweig (eds.), Women on the edge: four plays by Euripides, London/New York, 1999.

G. Bond, "Euripides' parody of Aeschylus", Hermathena 118, 1974, 1-14.

C. Bowra, "The two palinodes of Stesichorus", CR 13, 1963, 245-52.

A. P. Burnett, "Euripides' Helen: a Comedy of Ideas”, CPh 55, 1960, 151-163.

- Catastrophe survived: Euripides' plays of mixed reversal, Oxford, 1971, 76-100.

B. Cassin (ed.), Positions de la Sophistique. Colloque de Cerisy, Paris, 1986.

G. Cerri, "Dal canto citarodico al coro tragico: la Palinodia di Stesicoro, l'Elena di Euripide e le Sirene”, Dioniso 55, 19841985, 157-174.

C. J. Classen, "The study of language amongst Socrates' contemporaries," Die Sophistik, Darmstadt, 1976, 215-247.

J. A. Clota, "Studia Euripidea II - Helena en Eurípides", Helmantica 26, 1957, 197-212.

A. T. Cole, "The relativism of Protagoras", YClS 22, 1972, 19-45.

D. J. Conacher, Euripidean drama: Myth, theme and structure, Toronto, 1967.

_- "Rhetoric and relevance in euripidean drama", AJPh 102, 1981, 3-25. 
, Euripides and the Sophists, London, 1998.

E. Corsini, La polis e il suo teatro 1, Padova, 1986.

J. N. Deserto, Figuras sem nome em Eurípides, Lisboa, 1998.

M. Dirat, "Le Lyrisme d'Hélène", REG 89, 1976, 292-316.

—_, "Le personnage de Ménélas dans Hélène”, Pallas 23, 1976, 3-17.

M. Doria, "Le due Palinodie di Stesicoro", PP 18, 1963, 81-93.

E. Downing, "Apatê, agôn and literary self-reflexivity in Euripides' Helen", in M. Griffith, D.J. Mastronarde (eds.), Cabinet of the Muses: Essays on Classical and Comparative Literature in Honour of Thomas G. Rosenmeyer, Atlanta , 1990.

T. S. Duncan, "Gorgias' theories of art”, CJ 33, 1937-38, 402-415.

E. Dupréel, Les Sophistes, Neuchâtel et Bruxelles, 1948.

H. Foley, "Anodos Dramas: Euripides' Alcestis and Helen" in R. Hexter, D. Selden (eds.), Inovations of Antiquity, London, 1992, 133-160.

P. B. R. Forbes, "Greek pioneers in philology and grammar", $C R$ 47, 1933, 105-112.

M. Gagarin (ed.), Early Greek political thought from Homer to the Sophists, Cambridge, 1995.

D. L. Gera, "Two thought experiments in the Dissoi Logoi", AJPh121.1, 2000, 21-45.

J. Gregory, "Euripides as a social critic”, $G \& R 49$, 2002, 145-162.

J. G. Griffith, "Some thoughts on the Helena of Euripides", JHS 73, 1953, 36-41.

G. Grube, The drama of Euripides, London, 1941.

W. K. C. Guthrie, The sophists, Cambridge, 1971.

E. Hall, Inventing the barbarian. Greek self-definition through tragedy, Oxford, 1989. 
R. Hamilton, "Prologue, prophecy and plot in four plays of Euripides", AJPh 99.3, 1978, 277-302.

K.V. Hartigan, "Myth and the Helen", Eranos 79.1, 1981, 23-31.

I. E. Holmberg, "Euripides' Helen: most noble and most chaste", AJPh 116.1, 1995, 19-42.

I. Jong, Narrative in the drama: the art of the Euripidean messenger speech, Leiden, 1991.

F. Jouan, "Euripide et la rhétorique", LEC 52,1984, 3-13.

D. M. Juffras, "Helen and other victims in Euripides' Helen", Hermes 121.1, 1993, 45-57.

G. Karsai, “Teucros dans l'Hélène d'Euripide”, Pallas 38, 1992, $217-$ 226.

G. Kerferd, The sophistic movement, Cambridge, 1981.

A. M. E. T. Kip, "Truth in tragedy: when are we entitled to doubt a character's words?”, AJPh 117. 4, 1996, 517-536.

H. D. F. Kitto, A tragédia grega. Trad. Port. J. M. C. Castro, Coimbra, 1990.

A. M. Komornicka, "Hélène de Troie et son 'double' dans la littérature grecque (Homère et Euripide)", Euphrosyne 19, 1991, 9-26.

H. Lausberg, Elementos de retórica literária. Tradução, prefácio e aditamentos de R. M. Rosado Fernandes, Lisboa, ${ }^{5} 2004$.

A. Lesky, História da Literatura Grega. Trad. Port. Manuel Losa, Lisboa, 1995.

E. Lévy, "Naissance du concept de barbare", Ktema 9, 1984, 5-14.

G. Ley, "Scenic notes on Euripides' Helen”, Eranos 89.1, 1991, 25-34.

A. López Eire, "Un mito de la retórica de Górgias", O mito de Helena: de Tróia à actualidade, vol. I, Coimbra, 2007, 213-53.

F. Lourenço, "An interpolated song in Euripides? Helen 229-52", JHS 120, 2000, 132-139. 
—_, "Efeitos de contraste na lírica Euripidiana”, Grécia Revisitada, Lisboa, ${ }^{3} 2004,161-168$.

- "Eurípides: Trágico no superlativo", Grécia Revisitada, Lisboa, ${ }^{3} 2004$, 58-63.

_- "Helena na epopeia homérica", O mito de Helena: de Tróia à actualidade, vol. I, Coimbra, 2007, 47-53.

N. Marini, "Il personaggio di Calliroe come 'nuova Elena' e la mediazione comica di un passo euripideo", SIFC 11, 1993, 205-15.

G. S. Meltzer, "'Where is the glory of Troy?: Kleos in Euripides' Helen”, C. A. 13, 1994, 234-255.

C. Morenilla, "La Helena de Eurípides", O mito de Helena: de Tróia à actualidade, vol. I, Coimbra, 2007, 179-203.

D. G. Papi "Victors and sufferers in Euripides' Helen" AJPh 108.1, 1987, 27-40.

M. P. F. Pinheiro, "Origens gregas do género", F. Oliveira et alii (coord.), O romance antigo: origens de um género literário, Coimbra, 2005, 9-32.

A. J. Podlecki, "The basic seriousness of Euripides' Helen, TAPhA" 101, 1970, 401-418.

L.A. Post, "Menander and the Helen of Euripides", HSCP 68, 1964 , 99-118.

M. O. Pulquério, "A Actuação dos deuses na Helena de Eurípides", Humanitas 27-28, 1975-1976, 209-225.

M. Rabanal Alvarez, "Lo que hay de trágico en la Helena de Eurípides", ECláss. 65, 1962, 57-65.

D. B. Robinson, "Helen and Persephone, Sparta and Demeter. The 'Demeter ode' in Euripides' Helen", Arktouros, New York, 1979, 162-172.

G. Romeyer-Dherbey, Os Sofistas, Trad. Port. João Amado, Lisboa, 1986. 
J. Romilly, La modernité d'Euripide, Paris, 1986.

— - "La belle Hélène et l'évolution de la tragédie grecque", $L E C$ 56, 1988, 129-143.

—_ Les grandes sophistes dans l'Athène de Périclès, Paris, 1988.

S. Saïd, "Grecs et barbares dans les tragédies d'Euripide. La fin des différences?”, Ktema 9, 1984, 27-53.

D. Sansone, "Euripides, Helen 115-123", CQ 32, 1982, 56-58. , "Theonoe and Theoclymenus", SO 60, 1985, 17-36.

E. Schiappa, Protagoras and Logos. A Study in Greek Philosophy and Rethoric, Columbia, $2003^{2}$.

R. Schmiel, "The recognition duo in Euripides' Helen", Hermes 100.3, 1972, 274-294.

C. Segal, "The two worlds of Euripides' Helen", TAPhA 102, 1971, 553-614.

—_ "Les deux mondes de l'Hélène d'Euripide", REG 85, 1972, 293-311.

E. E. Sikes, The Greek view of poetry, New York/London 1969.

M. F. Silva, "Elementos visuais e pictóricos na tragédia de Eurípides", Humanitas 37-38, 1986, 9-86.

—., Critica do Teatro na Comédia Antiga, Lisboa, 1997.

—-, "Ecos da Odisseia na Helena de Eurípides", Máthesis 13, 2004, 227-242.

—_, "Representaçóes de alteridade no teatro de Eurípides: o bárbaro e o seu mundo", in Génese e consolidação da ideia de Europa, vol. I, Coimbra, 2005, 187-237.

- "Vida e morte na Helena de Eurípides", Ensaios sobre Euripides, Lisboa, 2005, 269-284.

__ "Helena, um exemplo de futilidade feminina e de snobismo bárbaro", O mito de Helena: de Tróia à actualidade, vol. I, 
Coimbra, 2007, 89-103.

"A porta na comédia de Aristófanes. Uma entrada para a utopia”, Ensaios sobre Aristófanes, Lisboa, 2007, 257-74.

F. Sisti, "Le due Palinodie di Stesicoro", StudUrb 39, 1965, 301-13.

C. L. Soares, "Rapto e resgate de Helena nas Histórias de Heródoto", O mito de Helena: de Tróia à actualidade, vol. I, Coimbra, 2007, 81-88.

A. Sowa, Traditional themes and the Homeric Hymns, Chicago, 1984.

D. P. Stanley-Porter, "Who opposes Theoclymenus", CP 72, 1977, $45-8$.

E. Suárez de la Torre, "Helena, de la épica a la lírica griega arcaica (Safo, Alceo, Estesícoro)", O mito de Helena: de Tróia à actualidade, vol. I, Coimbra, 2007, 55-79.

O. Taplin, Greek tragedy in action, Los Angeles, 1978.

S. N. Taragna, "Forma linguistica del contrasto realta-apparenza nell'Elena”, La Polis e il Suo Teatro 1, Padova, 1986, 127-49.

E. Turolla, "Commedie tragiche nel teatro euripideo", PP 8/2, 1953, 81-100.

M. Untersteiner, I Sofisti, Milano, 1949.

P. Vellacott, Ironic drama. A study of Euripides' method and meaning, Cambridge, 1975.

P. Vicaire, Platon critique litéraire, Paris, 1960.

M. Vickers, "Alcibiades on stage: Thesmophoriazusae and Helen" Historia 38/1, 1989, 41-65.

T.B.L. Webster, The tragedies of Euripides, London, 1967.

E. L. Wheeler, "Sophistic interpretations and Greek treaties", GRBS 25.3, 1984, 253-274.

C. W. Willink, “The reunion duo in Euripides' Helen”, CQ 39.1, 1989, 45-69. 
—, "The parodos of Euripides's Helen (164-90)", CQ 40.1, 1990, 77-99.

C. Wolff, "On Euripides' Helen”, HSCPh 77, 1973, 61-84.

L. Woodbury, "Helen and the Palinode", Phoenix 21, 1967, 157-76.

D. C. C. Young, "The text of the recognition duet in Euripides' Helena", GRBS 15.1, 1974, 39-56.

G. Zuntz, "On Euripide's Helena: theology and irony", Entretiens Hardt 6, 1960, 191-241.

B. Zweig, "Euripides' Helen: introduction and translation", Women on the edge: four plays by Euripides, New York, 1999, 219-301. 


\section{Volumes publicados na ColecÇÃo Autores GREGos E LATINOS - SÉRIE TEXTos GREGos}

1. Delfim F. Leão e Maria do Céu Fialho: Plutarco. Vidas Paralelas - Teseu

e Rómulo. Tradução do grego, introdução e notas (Coimbra, $\mathrm{CECH}, 2008)$.

2. Delfim F. Leão: Plutarco. Obras Morais - O banquete dos Sete Sábios. Tradução do grego, introdução e notas (Coimbra, CECH, 2008).

3. Ana Elias Pinheiro: Xenofonte. Banquete, Apologia de Sócrates. Tradução do grego, introdução e notas (Coimbra, CECH, 2008).

4. Carlos de Jesus, José Luís Brandão, Martinho Soares, Rodolfo Lopes: Plutarco. Obras Morais - No Banquete I - Livros I-IV. Tradução do grego, introdução e notas. Coordenação de José Ribeiro Ferreira (Coimbra, CECH, 2008).

5. Ália Rodrigues, Ana Elias Pinheiro, Ândrea Seiça, Carlos de Jesus, José Ribeiro Ferreira: Plutarco. Obras Morais - No Banquete II - Livros V-IX. Tradução do grego, introdução e notas. Coordenação de José Ribeiro Ferreira (Coimbra, CECH, 2008).

6. Joaquim Pinheiro: Plutarco. Obras Morais - Da Educação das Crianças. Tradução do grego, introdução e notas (Coimbra, CECH, 2008).

7. Ana Elias Pinheiro: Xenofonte. Memoráveis. Tradução do grego, introdução e notas (Coimbra, CECH, 2009).

8. Carlos de Jesus: Plutarco. Obras Morais - Diálogo sobre o Amor, Relatos de Amor. Tradução do grego, introdução e notas (Coimbra, $\mathrm{CECH}, 2009)$.

9. Ana Maria Guedes Ferreira e Ália Rosa Conceição Rodrigues: Plutarco. Vidas Paralelas - Péricles e Fábio Máximo. Tradução do grego, introdução e notas (Coimbra, CECH, 2010). 
10. Paula Barata Dias: Plutarco. Obras Morais - Como Distinguir um Adulador de um Amigo, Como Retirar Benefício dos Inimigos, Acerca do Número Excessivo de Amigos. Tradução do grego, introdução e notas (Coimbra, CECH, 2010).

11. Bernardo Mota: Plutarco. Obras Morais - Sobre a Face Visivel no Orbe da Lua. Tradução do grego, introdução e notas (Coimbra, $\mathrm{CECH}, 2010)$.

12. J. A. Segurado e Campos: Licurgo. Oração Contra Leócrates. Tradução do grego, introdução e notas (Coimbra, CECH /CEC, 2010).

13. Carmen Soares e Roosevelt Rocha: Plutarco. Obras Morais - Sobre o Afecto aos Filhos, Sobre a Música. Tradução do grego, introdução e notas (Coimbra, CECH, 2010).

14. José Luís Lopes Brandão: Plutarco. Vidas de Galba e Otão. Tradução do grego, introdução e notas (Coimbra, CECH, 2010).

15. Marta Várzeas: Plutarco. Vidas de Demóstenes e Cícero. Tradução do grego, introdução e notas (Coimbra, CECH, 2010).

16. Maria do Céu Fialho e Nuno Simóes Rodrigues: Plutarco. Vidas de Alcibiades e Coriolano. Tradução do grego, introdução e notas (Coimbra, CECH, 2010).

17. Glória Onelley e Ana Lúcia Curado: Apolodoro. Contra Neera. [Demóstenes] 59. Tradução do grego, introdução e notas (Coimbra, CECH, 2011).

18. Rodolfo Lopes: Platão. Timeu-Critías. Tradução do grego, introdução e notas (Coimbra, CECH, 2011).

19. Pedro Ribeiro Martins: Pseudo-Xenofonte. A Constituiçâo dos Atenienses. Tradução do grego, introdução, notas e índices (Coimbra, CECH, 2011).

20. Delfim F. Leão e José Luís L. Brandão: Plutarco. Vidas de Sólon e Publicola. Tradução do grego, introdução, notas e índices (Coimbra, CECH, 2012). 
21. Custódio Magueijo: Luciano de Samósata I. Tradução do grego, introdução e notas (Coimbra, CECH/IUC, 2012).

22. Custódio Magueijo: Luciano de Samósata II. Tradução do grego, introdução e notas (Coimbra, CECH/IUC, 2012).

23. Custódio Magueijo: Luciano de Samósata III. Tradução do grego, introdução e notas (Coimbra, CECH/IUC, 2012).

24. Custódio Magueijo: Luciano de Samósata IV. Tradução do grego, introdução e notas (Coimbra, CECH/IUC, 2013).

25. Custódio Magueijo: Luciano de Samósata V. Tradução do grego, introdução e notas (Coimbra, CECH/IUC, 2013).

26. Custódio Magueijo: Luciano de Samósata VI. Tradução do grego, introdução e notas (Coimbra, CECH/IUC, 2013).

27. Custódio Magueijo: Luciano de Samósata VII. Tradução do grego, introdução e notas (Coimbra, CECH/IUC, 2013).

28. Custódio Magueijo: Luciano de Samósata VIII. Tradução do grego, introdução e notas (Coimbra, CECH/IUC, 2013).

29. Custódio Magueijo: Luciano de Samósata IX. Tradução do grego, introdução e notas (Coimbra, CECH/IUC, 2013).

30. Reina Marisol Troca Pereira: Hiérocles e Filágrio. Philogelos ( $O$ Gracejador). Tradução do grego, introdução e notas (Coimbra, CECH/IUC, 2013).

31. J. A. Segurado e Campos: Iseu. Discursos. VI. A herança de Filoctémon. Tradução do grego, introdução e notas (Coimbra, CECH/IUC, 2013).

32. Nelson Henrique da Silva Ferreira: Aesopica: a fábula esópica e a tradição fabular grega. Estudo, tradução do grego e notas. (Coimbra, CECH/IUC, 2013). 
33. Carlos A. Martins de Jesus: Baquílides. Odes e Fragmentos Tradução do grego, introdução e notas (Coimbra e São Paulo, IUC e Annablume, 2014).

34. Alessandra Jonas Neves de Oliveira: Eurípides. Helena. Tradução do grego, introdução e notas (Coimbra e São Paulo, IUC e Annablume, 2015). 
Este livro pretende oferecer uma traduçáo, acompanhada de um estudo introdutório e de um amplo conjunto de notas, da Helena de Eurípides. No estudo introdutório são abordadas as questôes mais significativas na interpretação desta peça que figura entre as 'tragicomédias' do autor. 
OBRA PUBLICADA

COM A COORDENAÇÁO

CIENTÍFICA

0

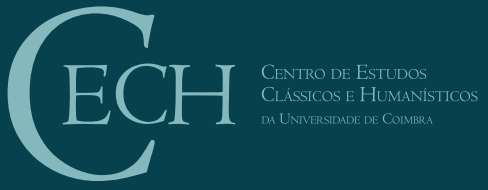

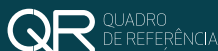
COMPETE

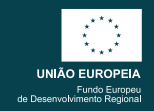

